\title{
AVALIAÇÃO DOS EFEITOS DO ULTRA-SOM PULSADO DE BAIXA \\ INTENSIDADE E DA ATIVIDADE FÍSICA NA MUSCULATURA ESQUELÉTICA DE RATOS SUBMETIDOS AO ALCOOLISMO CRÔNICO E POSTERIOR LESÃO POR IMPACTO PADRONIZADA.
}

Dissertação apresentada ao Programa de PósGraduação Interunidades em Bioengenharia - Escola de Engenharia de São Carlos / Faculdade de Medicina de Ribeirão Preto / Instituto de Química de São Carlos - da Universidade de São Paulo, como parte dos requisitos para a obtenção do título de Mestre em Bioengenharia.

Orientador: Prof. Dr. Affonso Luiz Ferreira 
Avaliação dos efeitos do ultra-som pulsado de baixa intensidade e da atividade física na musculatura esquelética de ratos submetidos ao alcoolismo crônico e posterior lesão por impacto padronizada / Talita Andrea Bordini Malaman. -- São Carlos, 2006.

Dissertação (Mestrado) -- Escola de Engenharia de São Carlos-Universidade de São Paulo, 2006.

Área: Bioengenharia.

Orientador: Prof. Dr. Affonso Luiz Ferreira.

1. Alcoolismo. 2. Ultra-som. 3. Lesão muscular experimental. 4. Treinamento físico. I. Título. 
Dedico este trabalho aos meus pais Magali e Fiore pelo apoio dado nos momentos difíceis, quando pensava em desistir de tudo, pelo incentivo a seguir em frente, pela compreensão e paciência e acima de tudo pela dedicação e esforços realizados durante todo este período de estudo. Ao meu namorado Rafael pela compreensão. 


\section{AGRADECIMENTOS}

Agradeço as palavras, gestos, e a presença de pessoas que se fizeram permanecer, como ponto de apoio, durante toda a realização deste trabalho.

A Deus por me mostrar os caminhos por onde trilhar dando-me forças para superar as minhas dificuldades.

A Professora Mestre Ana Rosa Crisci pelo carinho e amizade com que me ajudou no trabalho.

Ao professor Doutor Vilmar Baldissera, que sempre esteve presente quando precisei de ajuda, sempre compartilhando seus ensinamentos e, abriu as portas juntamente com o professor Doutor Sérgio Eduardo de Andrade Perez, do laboratório de Fisiologia do Exercício (UFSCar), fazendo com que este trabalho se tornasse exeqüível.

Ao Professor Doutor Luciano Neder, que atenciosamente me acolheu no seu laboratório de Patologia da USP, permitindo que realizasse as técnicas histoenzimológicas e a Professora Doutora Ana Claúdia Mattielo-Sverzutti que me possibilitou utilizar o equipamento para a contagem da área das fibras musculares.

Aos técnicos José Carlos Lopes (Cacau) (UFSCar), Maria Paula Scandar (USPRP), Rubilan (Barão de Mauá) que com suas enorme experiências de trabalho em laboratório, puderam me ensinar tudo aquilo que precisei aprender, para tornar este trabalho possível, além de terem sido grandes amigos em todas as horas.

A Profa.Dra. Heloisa Sobreiro Selistre de Araújo pelo empréstimo do galão de nitrogênio para o transporte dos fragmentos dos músculos.

As técnicas do Departamento de biologia celular e biopatogênese, Maria Tereza Maglia e Tuca no auxílio da preparação das lâminas de semi-fino.

As secretárias do Programa Interunidades em Bioengenharia, Janete Ferreira Rodrigues dos Santos e Bárbara Fernanda de Luccas, pela presteza, dedicação e enorme competência em suas funções.

A secretária da Fisiologia do Esforço da UFSCar Luciana Fernandes, pela amizade e competência em sua função. 
Ao Professor Doutor José Carlos Pereira e em especial ao Professor César Terçariol pelo auxílio na execução da estatística e dos gráficos do trabalho.

A Professora Doutora Tânia de Fátima Salvini e ao colega Fabrício Borges de Oliveira pelo empréstimo dos equipamentos de produção da lesão experimental.

A Professora Alessandra Marta Stocco pela ajuda na revisão do Abstract do trabalho.

Aos meus colegas e amigos, Sérgio Parada, Claúdia Cristiane Camilo, Grazielle Pereira de Oliveira, Maria Inês de Souza, Lourdes Cristina de Albuquerque Haah, pela ajuda na execução deste trabalho, pelo apoio, incentivo e amizade.

As colegas Andrezza F. Cruz, Juliana Goulart Prata de Oliveira, Giovana Leitão Sene pela ajuda e presteza.

As colegas Anabelle Cornachione, Camila Freitas, Natália Padula, Letícia Cação Benedini de Oliveira e Priscila Cação Benedini de Oliveira pelo auxílio com o equipamento de contagem das fibras musculares.

A minha avó Neide que além de me acolher de braços abertos em sua casa quando precisava também me ensinou que nunca devemos desistir de nossos sonhos.

Aos meus avós Toninho e Chiquita (in memorian) que sempre torceram por mim.

Ao meu namorado Rafael Carlos de Jesus pela ajuda na formatação e realização deste trabalho.

Às minhas amigas Ana Carolina Martini Medeiros Silva e Tammy Locali, pelo apoio dado nas horas difíceis.

Aos meus tios, primos e amigos que auxiliaram a construir este trabalho.

E por fim a todos os meus bichinhos por terem sido o instrumento para meu conhecimento. 


\section{AGRADECIMENTOS ESPECIAIS}

Ao Professor Doutor Affonso Luiz Ferreira pelo carinho, confiança, dedicação, simplicidade, ética, humildade, caráter e acima de tudo pela amizade.

Aos meus pais Fiore e Magali pelo patrocínio, pela ajuda dada para a realização deste trabalho e por sempre acreditarem-nos mesmos sonhos. 
"Talvez não tenhamos conseguido fazer o melhor. Mas lutamos para que o melhor fosse feito. Não somos o que deveríamos ser, não somos o que iremos ser, mas graças a Deus não somos o que éramos"

Martir Luther King 


\section{RESUMO}

MALAMAN, T.A.B. Avaliação dos Efeitos do Ultra-Som Pulsado de Baixa Intensidade e da Atividade Física na Musculatura Esquelética de Ratos Submetidos ao Alcoolismo Crônico e Posterior Lesão por Impacto Padronizada. 2006. 110p. São Carlos. Dissertação (Mestrado) - Escola de Engenharia de São Carlos/ Faculdade de medicina de Ribeirão Preto/ Instituto de Química de São Carlos, Universidade de São Paulo.

O tecido muscular esquelético é dentre os tecidos do organismo um dos principais afetados em decorrência do uso abusivo do álcool. Neste trabalho nosso objetivo foi o de quantificar os efeitos do alcoolismo crônico experimental sobre a musculatura esqueléticas de ratos submetidos ou não a atividade física padronizada, bem como avaliar a regeneração muscular após mecanismo de lesão muscular aguda, no músculo gastrocnêmio, através de trauma direto não-invasivo associado posteriormente ao tratamento de 3 dias com ultra-som pulsado de baixa intensidade (USP). Para tanto, foi utilizado 20 ratos Wistar divididos em 4 grupos experimentais: grupo I alcoólatra sedentário lesado por impacto e estimulado com USP, grupo II controle sedentário lesado por impacto e estimulado com USP, grupo III alcoólatra treinado lesado por impacto e estimulado com USP e grupo IV controle treinado lesado por impacto e estimulado com USP.

Após o período estabelecido, os animais foram sacrificados. O gastrocnêmio e o sóleo direito foram coletados para quantificar a histomorfometria e o gastrocnêmio esquerdo foi retirado para análise histológica da regeneração muscular.

Os nossos resultados sugerem que a recuperação das fibras musculares dos ratos alcoólatras avaliados histopatologicamente, apresentam sinais de lesões mais acentuadas que as fibras dos ratos controles submetidos às mesmas condições. E que nosso esquema de alcoolismo crônico não foi efetivo na indução da miopatia alcoólica crônica.

Palavras-chaves: Alcoolismo, Ultra-som, Lesão Muscular Experimental, Treinamento Físico. 


\begin{abstract}
MALAMAN, T.A.B. Avaliação dos Efeitos do Ultra-Som Pulsado de Baixa Intensidade e da Atividade Física na Musculatura Esquelética de Ratos Submetidos ao Alcoolismo Crônico e Posterior Lesão por Impacto Padronizada. 2006. 110p. São Carlos. Dissertação (Mestrado) - Escola de Engenharia de São Carlos/ Faculdade de medicina de Ribeirão Preto/ Instituto de Química de São Carlos, Universidade de São Paulo.
\end{abstract}

The skeletal muscle tissue is among the organism tissues one of the most affected by the abuse alcohol. The aim of this study was quantify the effects of chronic alcoholism on skeletal muscle of rats submitted or not to exercise training model, as well evaluate the muscle regeneration after mechanism of acute muscular injury, in the gastrocnemius muscle, through a direct non-invasive trauma subsequently associated with a treatment of 3 days with low intensity pulsed ultrasound (USP). For that, it was used twenty male Wistar rats were allocated into 4 experimental groups: group I alcoholic without practice exercise training affected by an impact and stimulated with USP, group II control without practice exercise training affected by an impact and stimulated with USP, group III alcoholic with practice exercise training affected by an impact and stimulated with USP and group VI control with practice exercise training affected by an impact and stimulated with USP. All groups suffered muscular injury and stimulation with USP. After this period, the animals were killed. The right gastrocnemius and soleus were collected for detail quantitative histomorphometry and the left gastrocnemius muscle was removed for histology analysis of muscle regeneration.

Ours results suggest that fiber muscle recuperation of the alcoholic rats evaluated histopathology, show deeper damaged signs that control rat's fibers in the same condition. And ours diagram of chronic alcolism was not effective in the induce chronic alcoholic myopathy.

Key words: Alcoholic, Ultrasound, Experimental Muscle Injury, Exercise Training. 


\section{LISTA DE FIGURAS}

Figura 01. Circuito de Biotransformação do álcool .......................................... 28

Figura 02. Tipos de Músculos ........................................................................... 29

Figura 03. Esquema da origem embrionária do músculo esquelético .............. 31

Figura 04. Tecido conjuntivo que envolve o músculo esquelético ................... 33

Figura 05. Esquema Ilustrativo da Microestrutura Muscular .......................... 36

Figura 06. Relação entre a troponina, tropomiosina, as pontes cruzadas da miosina e o cálcio .................................................................................. 38

Figura 07. Esquema do ouvido humano e suas respectivas estruturas ............. 49

Figura 08. Deslocamento de uma partícula em função da distância ................ 50

Figura 09. Deslocamento de uma partícula em função do tempo .................... 51

Figura 10. Regime de Propagação Contínuo ......................................................... 53

Figura 11. Regime de Propagação Pulsado ......................................................... 53

Figura 12. Comportamento do feixe ultra-sônico tornando-se mais regular com a proximidade do campo distante .............................................. 54

Figura 13.Variação da intensidade acústica (I) nos campos ultra-sônicos próximos e distantes, em meio aquoso. No primeiro gráfico tem-se a variação da I ao longo do eixi $x$, no segundo tem-se a variação de I ao longo do eixo y ( perpendicular à pagina), e nos dois últimos, o valor da intensidade média ao longo do eixo y, numa determinada posição ............................................................................... 55

Figura 14. Reflexão e Refração do Ultra-som ..................................................59

Figura 15. Representação de uma balança de força de radiação ....................... 65

Figura 16. Esteira elétrica utilizada pra o treinamento dos animais .................. 75

Figura 17. Demonstração da tricotomia do ventre muscular .............................. 75

Figura 18. Posicionamento do animal antes da queda do peso para a produção da lesão experimental ......................................................................... 76 
Figura 19. A seqüência das figuras $\mathrm{A}, \mathrm{B}$ e $\mathrm{C}$ mostraram respectivamente, o aparelho utilizado para a lesão experimental, o posicionamento do peso após a lesão e o aspecto da lesão

Figura 20. Equipamento utilizado para a sonificação dos animais, timer utilizado para a marcação do tempo e gel hidrossolúvel.

Figura 21. Tubo de contenção utilizado para a realização do ultra-som 78

Figura 22. As fotos acima representam os equipamentos utilizados para a realização da análise morfométrica dos tipos de fibras musculares: Câmera de vídeo Leica DFC 300 FX, Microscópio de luz binocular Leica DM 2500, Microcomputador, Programa QualiView 80

Figura 23. As fotos A e B representam cortes de reações histoenzimológi-cas do músculo gastrocnêmio nos pHs 9,4 e 4,6 respectivamente (as setas indicam a diferenciação em fibras claras e escuras das mesmas fibras musculares em $\mathrm{pHs}$ diferentes) e a foto $\mathrm{C}$ mostra o mesmo corte acima, corado com H.E 81

Figura 24. O gráfico acima representa a comparação entre as áreas dos tipos de fibras, I e II, e as variáveis; ingestão de álcool e água, nos animais sedentários, no músculo sóleo.

Figura 25. O gráfico acima representa a comparação entre as áreas dos tipos de fibras, I e II, e as variáveis; ingestão de álcool e água, nos animais treinados, no músculo sóleo.

Figura 26. O gráfico acima representa a comparação entre as áreas dos tipos de fibras, I e II, e as variáveis; ingestão de álcool e água, nos animais sedentários, no músculo gastrocnêmio 84

Figura 27. O gráfico acima representa a comparação entre as áreas dos tipos de fibras, I e II, e as variáveis; ingestão de álcool e água, nos animais treinados, no músculo gastrocnêmio. 85

Figura 28. O gráfico acima representa a comparação entre os animais sedentários e treinados, e as variáveis; ingestão de álcool e água e tipo de fibra I, no músculo sóleo. 86

Figura 29. O gráfico acima representa a comparação entre os animais sedentários e treinados, e as variáveis; ingestão de álcool e água e tipo de fibra II, no músculo sóleo. 86

Figura 30. O gráfico acima representa a comparação entre os animais que ingeriram água ou álcool e as variáveis treinado e sedentário e o tipo de fibra I, no músculo gastrocnêmio. 
Figura 31. O gráfico acima representa a comparação entre os animais que ingeriram água ou álcool e as variáveis treinado e sedentário e o tipo de fibra II, no músculo gastrocnêmio.

Figura 32. A seqüencia de fotomicrografias A1, B1, C1, D1, E1 e F1, representa os aspectos histológicos do corte transversal do músculo gastrocnêmio esquerdo do grupo I (alcoólatra sedentário): (A1, CI e E1) Infiltrado inflamatório, corado com Hemalumem-eosina (H.E.) A1 e E1, em Tricrômico de Gomori C1 (estrela), (B1) Fragmentação intracelular em H.E. (seta), (C1) Área de hemorragia em Tricrômico de Gomori (seta grossa), (D1 e F1) Necrose da fibra muscular, em H.E. (cabeça de seta). (Aumento de cax respectivamente 20x e 40x)

Figura 33. A seqüência de fotomicrografias A3, B3, C3, D3, E3 e F3, representa aspectos histopalógicos da fibra do músculo gastrocnêmio esquerdo, do grupo III (alcoólatra treinado): (A3, B3 e C3) Infiltrado inflamatório em Tricrômico de Gomori (estrela), (B3 e F3) Fragmentação intracelular representada na lâmina B3 corada com Tricrômico de Gomori e na lâmina F3 corada com H.E. (seta), (E3 e F3) Aumento do número de núcleos periféricos na fibra muscular, lâminas coradas em H.E. (cabeça de seta). (Aumento de cax respectivamente $20 \mathrm{x}$ e $40 \mathrm{x}$ ).

Figura 34. A seqüência de fotomicrografias A2, B2, C2, D2, E2 e F2, representa aspectos histológicos em corte transversal do músculo gastrocnêmio esquerdo do grupo II (controle sedentário): (A2 e B2) Pequeno infiltrado inflamatório, coloração H.E. (seta), (D2 e F2) Fragmentação intracelular, lâmina D2 corada em H.E. e lâmina F2 corada em Tricrômico de Gomori (cabeça de seta). (Aumento de cax respectivamente $20 \mathrm{x}$ e $40 \mathrm{x}$ )......

Figura 35. A seqüência de fotomigrografias A4, B4, C4, D4, acima, representa aspectos histológicos em corte transversal do músculo gastrocnêmio esquerdo, do grupo IV(controle treinado): (A4 e B4) Aumento no número de núcleos periféricos, lâminas coradas em H.E. (cabeça de seta), (C4 e D4) Fragmentação intrafibrilar, lâminas coradas em Tricrômico de Gomori (seta). (Aumento de cax respectivamente 20x e 40x) 


\section{LISTA DE TABELAS}

Tabela 01. Características das fibras musculares esqueléticas baseadas nas propriedades físicas e metabólicas

Tabela 02. Coeficiente de atenuação (a) em diferentes tecidos para a freqüência de $1 \mathrm{Mhz}$

Tabela 03. Propriedades acústicas de vários meios. 58

Tabela 04. Valores obtidos com a comparação entre as áreas dos tipos de fibras tipo I e II no músculo sóleo, e as variáveis; a ingestão de álcool ou água, e animais treinados e sedentários.

Tabela 05. Valores obtidos com a comparação entre as áreas dos tipos de fibras tipo I e II no músculo gastrocnêmio, e as variáveis; a ingestão de álcool ou água, e animais treinados e sedentários 85

Tabela 06. Valores obtidos com a comparação entre animais treinados e sedentários, e as variáveis; ingestão de álcool e água e tipo de fibras I e II, no músculo sóleo.

Tabela 07. Valores obtidos com a comparação entre animais que ingeriram água ou álcool e as variáveis treinado e sedentário e os tipo de fibras I e II, no músculo gastrocnêmio. 


\section{LISTA DE SÍMBOLOS E SIGLAS}

\begin{tabular}{|c|c|}
\hline $\mathrm{Hz}-$ & Hertz \\
\hline $\mathrm{kHz}-$ & Quilohertz \\
\hline$\lambda-$ & Comprimento de onda \\
\hline$\tau-$ & Período \\
\hline A - & Amplitude \\
\hline$P-$ & Potência \\
\hline W - & Watts \\
\hline E - & Energia \\
\hline$c-$ & Velocidade de propagação do som \\
\hline $\mathrm{m} / \mathrm{s}-$ & Metros por segundo (unidade de velocidade) \\
\hline I - & Intensidade \\
\hline m:e - & Relação marca /espaço \\
\hline $\mathrm{g} / \mathrm{ml}-$ & Grama por mililitro (unidade de densidade) \\
\hline $\mathrm{W} / \mathrm{cm}^{2}-$ & Watt por centímetro quadrado (unidade de intensidade) \\
\hline S - & Área \\
\hline $\mathrm{t}-$ & Tempo \\
\hline $\mathrm{a}-$ & Coeficiente de atenuação da onda \\
\hline $\mathrm{P}_{\text {ref- }}^{-}$ & Potência de referência \\
\hline$Z-$ & Impedância acústica \\
\hline$\rho-$ & Densidade \\
\hline $\mathrm{I}_{\mathrm{SPTP}}-$ & Intensidade pico temporal-pico espacial \\
\hline $\mathrm{I}_{\mathrm{SPTA}}-$ & Intensidade média temporal-pico espacial \\
\hline $\mathrm{I}_{\mathrm{SATA}}{ }^{-}$ & Intensidade média temporal-média espacial \\
\hline $\mathrm{I}_{\mathrm{SATP}}{ }^{-}$ & Intensidade de pico temporal-média espacial \\
\hline $\mathrm{I}_{0}-$ & Intensidade inicial \\
\hline$e-$ & Número de Neper \\
\hline$X-$ & Espessura de um material \\
\hline $\mathrm{MHz}-$ & Megahertz \\
\hline $\mathrm{mm}-$ & Milímetros \\
\hline $\mathrm{pH}-$ & Mensuração da acidez de uma solução \\
\hline $\mathrm{m}-$ & Massa \\
\hline $\mathrm{F}-$ & Força \\
\hline$g-$ & Aceleração da gravidade \\
\hline h - & Altura da liberação da carga \\
\hline$\Delta \mathrm{S}^{-1}$ & Deformação tecidual \\
\hline PZT - & Titanato zirconato de chumbo \\
\hline AIMD - & Doença muscular induzida pelo álcool \\
\hline $\mathrm{H}_{3} \mathrm{CH}_{2} \mathrm{OH}$ & Fórmula química do etanol \\
\hline $\begin{array}{c}\mathrm{ADH}- \\
\mathrm{H}^{+}-\end{array}$ & $\begin{array}{l}\text { Álcool desidrogenase } \\
\text { Íon hidrogênio }\end{array}$ \\
\hline $\mathrm{H}_{2} \mathrm{O}_{2}-$ & Água Oxigenada \\
\hline NAD - & Nicotinamida Adenosina Dinucleotídeo \\
\hline NADH - & Forma reduzida do NAD \\
\hline
\end{tabular}




\section{LISTA DE ABREVIATURAS}

$\begin{array}{ll}\text { Grea } & \text { Grupo Interdisciplinar de Estudos de Álcool e Drogas } \\ \text { SMOE } & \text { Sistema Microssomal de Oxidação do Etanol } \\ \text { OMS } & \text { Organização Mundial da Saúde } \\ \text { Senad } & \text { Secretaria Nacional Antidrogas } \\ \text { AA } & \text { Alcoólicos Anônimos } \\ \text { USP } & \text { Ultra-som pulsado de baixa intensidade } \\ \text { US } & \text { Ultra-som } \\ \text { H.E. } & \text { Hemalumem-eosina ou Hematoxilina-eosina } \\ \text { cax } & \text { Aumento de cerca de }\end{array}$




\section{SUMÁRIO}

RESUMO

ABSTRACT

LISTA DE FIGURAS

LISTA DE TABELAS

LISTA DE ABREVEATURAS E SIGLAS

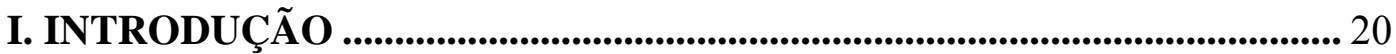

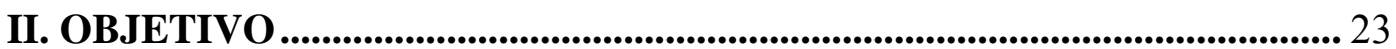

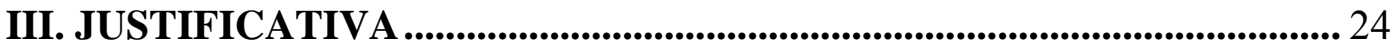

IV. GENERALIDADES DO METABOLISMO DO ÁLCOOL ...................... 25

V. TECIDO MUSCULAR .............................................................................. 29

5.1. Características morfológicas e funcionais dos músculos ........................ 29

5.2. Estrutura macroscópica do músculo estriado esquelético..................... 30

5.3. Ultra-estrutura do músculo estriado esquelético .................................... 34

5.4. Mecanismo Geral de Contração Muscular e a Teoria do Filamento

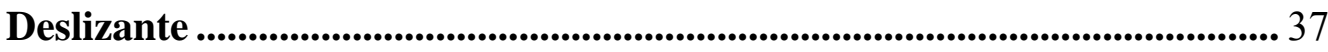

5.5. Tipos de fibras musculares ...................................................................... 38

5.6. O alcoolismo e os sistemas orgânicos ................................................. 41

5.7. Regeneração do tecido muscular ......................................................... 44 


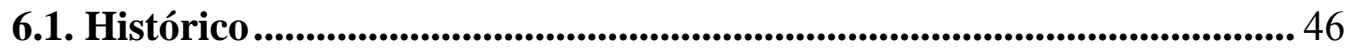

6.2. Bases Físicas ....................................................................................... 48

6.2.1. Som e o ouvido humano.......................................................................... 48

6.2.2. Parâmetros físicos que caracterizam as ondas ultra-sônicas .......... 49

Comprimento de onda ............................................................................... 49

Amplitude.............................................................................................. 50

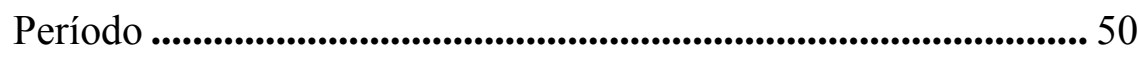

Freqüência .................................................................................................... 51

Potência........................................................................................................52

Velocidade de propagação....................................................................52

Modos de propagação........................................................................... 52

Intensidade.................................................................................................. 53

Atenuação..............................................................................................56

Tempo de irradiação e campo de aplicação........................................58

Impedância acústica................................................................................58

Reflexão e Refração............................................................................59

Transdutores...............................................................................................60

6.3. Interação do ultra-som com os tecidos.....................................................61

Cavitação..................................................................................................62

Microfluxo acústico e correntes acústicas.......................................... 63

Piezoeletricidade........................................................................................... 64

6.4. Dosimetria......................................................................................................64 
6.5. Princípios do reparo dos tecidos muscular após uma lesão e a atuação do ultra-som em cada fase.

6.5.1. Fase Inflamatória ou Inicial................................................66

6.5.2. Fase fibroblástica ou de proliferação...................................... 67

6.5.3. Fase de remodelamento ou maturação...................................66

VII. REVISÃO DA LITERATURA...........................................................69

VIII. MATERIAL E MÉTODOS...................................................................... 73

8.1. Animais de experimentação...................................................................73

8.2. Agrupamento.......................................................................................73

8.3.Programa de treinamento......................................................................... 74

8.4. Procedimento Experimental.............................................................. 75

8.4.1. Mecanismo de lesão................................................................................. 75

8.4.2. Tratamento com ultra-som pulsado de baixa intensidade................ 77

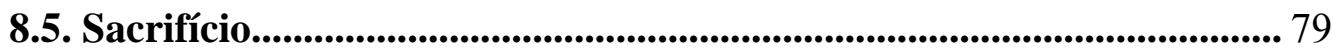

8.6. Obtenção dos cortes e análise histoenzimológica..................................... 79

8.7. Análise Estatística............................................................................................. 81

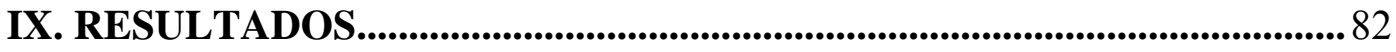

XI. DISCUSSÃO

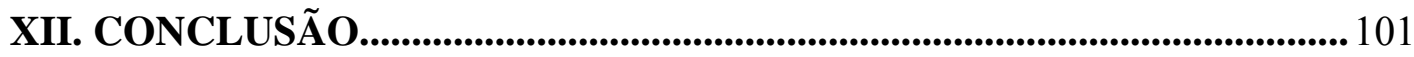

XIII. REFERÊNCIAS BIBLIOGRÁFICAS...................................................... 102 


\section{INTRODUÇÃO:}

O alcoolismo é um grave problema de saúde pública, médico e social, uma vez que o álcool é a droga mais comumente consumida de forma legal e de modo abusivo, em todo o mundo, sendo seu consumo social e culturalmente aceito (MASTERS, 2003).

Segundo Fortes (1975), há mais de oito mil anos já existiam provas arqueológicas indicativas do uso de bebidas alcoólicas sendo, portanto, um costume extremamente antigo e que tem persistido por milhares de anos.

A noção de álcool* como substância divina, por exemplo, pode ser encontrada em inúmeros exemplos na mitologia como Dionísio ou Baco (Deus do Vinho), sendo talvez um dos fatores responsáveis pela manutenção do hábito de beber ao longo do tempo.

Na sociedade ocidental, até o início do século XIX, bebidas alcoólicas como cerveja e vinho eram utilizados como fonte de líquidos em substituição à água, cuja ingestão estava reconhecidamente associada a doenças crônicas e agudas, além de fornecerem calorias e nutrientes. Após a introdução de melhores sistemas de saneamento básico e purificação da água estas bebidas perderam espaço na dieta humana passando a ser consumidas apenas socialmente como forma de recreação (MASTERS, 2003).

O processo de destilação foi desenvolvido pelos árabes em 800 a.D., e com o advento deste processo, introduzido na Europa pelos árabes na Idade Média, as preparações destiladas com maiores concentrações de álcool passaram a ser utilizadas, e empregadas também como remédio, tônicos e elixires, uma vez que, as pessoas creditavam que estas bebidas dissipavam as preocupações mais rapidamente do que o vinho e a cerveja, e produziam um alívio mais eficiente da dor, surgindo então a palavra whisky (do gálico usquebaugh, que significa "água da vida") ( DELUCIA e OLIVEIRA, 2004).

\footnotetext{
* os termos álcool, etanol e álcool etílico serão utilizados indiferenciadamente.
} 
Contudo, foi a partir da Revolução Industrial que se passou a registrar uma maior oferta e consumo de álcool, e conseqüentemente, maiores problemas decorrentes do uso abusivo do mesmo.

No Brasil, durante o período de escravidão, os escravos consumiam aguardente de cana, oferecida pelos capatazes, para que estes permanecessem mais dóceis ou para curar a depressão devido à saudade de sua terra (Banzo).

O alcoolismo foi incorporado pela Organização Mundial da Saúde (OMS) à Classificação Internacional das Doenças em 1967 (CID-8), a partir da 8ª Conferência Mundial de Saúde, sendo que a OMS, somente admitiu o alcoolismo como problema médico em 1951, e na década de 60, foi reconhecido como doença pela Associação Psiquiátrica Americana (DELUCIA e OLIVEIRA, 2004).

A Secretaria Nacional Antidrogas (Senad) em dados apresentados à Conferência Pan-americana de Políticas Públicas sobre o Álcool, aberta no dia 28 do novembro de 2005, estima em 19 milhões os brasileiros dependentes do álcool. De acordo com a Organização Mundial de Saúde (OMS), em dados apresentados na conferência, o consumo de bebidas alcoólicas por brasileiros cresceu 70,5\% em 35 anos, o que inclui o Brasil na lista dos 25 países que mais cresceu o uso de bebidas alcoólicas. Em países como Chile, Argentina, Canadá e Estados Unidos o consumo decresceu em (57,6\%), (48,2\%), (11,1\%), (15,1\%) respectivamente.

O maior consumidor mundial de bebida alcoólica é o do grupo que reúne Rússia e Ucrânia, com um consumo médio de 13,9 litros, sendo que individualmente a Uganda é líder, com 19,4 litros. O Brasil fica em $81^{\circ}$ lugar com um consumo médio de 5,3 litros por pessoa.

O alcoolismo se define como uma doença de natureza complexa, caracterizado por problemas psicossomáticos com repercussão no âmbito familiar, educacional, legal, financeiro, médico ou ocupacional devido ao uso continuado e abusivo do álcool.

Segundo o Senad o consumo excessivo de álcool é apontado como uma das principais causas de conflitos familiares ou conjugais, bem como insultos, agressões físicas, e homicídios, por pessoas embriagadas.

Em 1935, os Alcoólicos Anônimos (AA) definiram como alcoolista “toda pessoa vencida pelo álcool e cuja vida começa a ser incontrolável”. 
No Brasil, de acordo com o Grupo Interdisciplinar de Estudos de Álcool e Drogas (Grea) do Instituto de Psiquiatria do Hospital das Clínicas, em São Paulo cerca 15\% da população brasileira é alcoólatra.

Contudo, o álcool não atinge somente pessoas adultas, comuns ou de baixa renda. Hoje em dia um número expressivo de jovens, bem como atletas tem feito uso de bebidas alcoólicas, mesmo o álcool sendo considerado dopping em algumas modalidades esportivas.

Um exemplo clássico do término de sua carreira brilhante no esporte devido ao abuso do álcool e o de Mané Garrincha “o gênio das pernas tortas”, o legítimo representante do futebol arte, que morreu de edema pulmonar em decorrência do alcoolismo (CASTRO, 1995).

A ingestão freqüente e excessiva do álcool gera inúmeros problemas sobre os sistemas orgânicos, como sistema nervoso, sistema digestório, sistema hepático, sistema circulatório e muscular (VILA et al., 2001; ADACHI et al., 2003).

O abuso crônico do álcool afeta a musculatura esquelética, levando a Doença Muscular Induzida pelo Álcool (AIMD), sendo esta mais comum do que muitas outras enfermidades decorrentes do alcoolismo, como, cirrose, neuropatias periféricas, doenças intestinais ou cardiopatias (PREEDY et al., 2003).

Dois terços dos alcoólatras crônicos desenvolvem miopatia alcoólica, caracterizada por fraqueza muscular, quedas freqüentes, alterações da marcha e redução da massa muscular, com atrofia seletiva na fibra muscular tipo II (glicolítica, rápida, anaeróbica), sendo que a fibra tipo I (oxidativa, lenta, aeróbica) é minimamente afetada podendo exibir até uma hipertrofia compensatória (WORRAL et al., 2001).

Segundo PREEDY et al. (2001a), as alterações no metabolismo das proteínas, seria o ponto chave para a redução da massa muscular e do diâmetro da fibra, nos alcoolistas crônicos.

OHLENDIECK et al. (2003) relataram que o alcoolismo pode afetar a membrana muscular e reduzir o cálcio nos miotúbulos em humanos.

Diante do exposto, acreditamos que seria necessária uma adequação nos procedimentos fisioterapêuticos que envolvam pacientes dependentes do álcool, devido às alterações provocadas pelo mesmo na musculatura, bem como, seus efeitos deletérios no metabolismo como um todo. 


\section{OBJETIVO}

Mediante o fato do tecido muscular esquelético ser o mais abundante no organismo, e este ser um dos principais afetados em decorrência do uso abusivo do álcool, é propósito deste trabalho quantificar os efeitos do alcoolismo crônico experimental sobre fibras musculares de ratos, submetidos ou não a atividade física padronizada, bem como avaliar a regeneração da fibra muscular, pós lesão traumática padronizada associada posteriormente ao tratamento com ultra-som pulsado de baixa intensidade (USP). 


\section{JUSTIFICATIVA}

É fato demonstrado a integração entre o uso abusivo do álcool e as lesões nas fibras musculares, como pode ser constatado na introdução.

Assim, acreditamos que o alcoólatra não pode ser submetido ao mesmo protocolo de tratamento fisioterápico, indicado para um indivíduo não alcoólatra.

Pretendemos avaliar experimentalmente, mediante exercícios e lesões padronizadas, as conseqüências do alcoolismo crônico sobre a musculatura esquelética e posteriormente avaliar as repercussões do USP sobre as lesões musculares produzidas por impacto, nestes animais. 


\section{GENERALIDADES DO METABOLISMO DO ÁLCOOL}

O etanol (álcool) pode ser introduzido no organismo por diversas vias, podendo ser ingerido, inalado ou absorvido através da pele, sendo esta última forma desprezível (FORTES, 1975; DELUCIA e OLIVEIRA, 2004).

Usualmente, a administração do álcool ocorre por ingestão, na forma de cerveja (cuja concentração de etanol oscila em torno de 4\%), vinho (11-12\%), aguardentes (3854\%) (LARINI e SALGADO, 1997). Quando é ingerido, entra primeiramente em contato direto com a mucosa do palato, a língua e o esôfago onde se inicia o processo de absorção.

O álcool rapidamente atravessa a mucosa gástrica, local onde ocorre cerca de 20\% de sua absorção, e a mucosa intestinal, onde ocorre o restante de sua absorção passando para a circulação sanguínea destas áreas, por um processo de difusão simples não iônica (LARINI e SALGADO, 1997). Apesar das bebidas alcoólicas serem retidas no estômago por um maior período de tempo, antes de serem transferidas para o intestino delgado, a absorção pelo intestino delgado é mais rápida e completa que no estômago, pois independe da presença de alimentos ou da quantidade de bebida, além de possuir uma área de superfície de contato maior que a do estômago e por apresentar fisiologicamente condições e provisão sanguínea que condicionam a reabsorção mais rápida. No entanto, se a concentração alcoólica for muito elevada pode haver um espasmo do piloro, impedindo a passagem para o intestino, retardando desta forma a absorção. (DELUCIA e OLIVEIRA, 2004).

Existem diversos fatores que podem influenciar a maior ou menor absorção do álcool pelo organismo, tais como: tipo e a natureza da bebida alcoólica, do $\mathrm{pH}$ do meio, da concentração da bebida, do estado de vacuidade ou repleção do estômago (pois, em média, a ingestão de $120 \mathrm{ml}$ de aguardente de cana com estômago vazio, resulta em uma concentração sanguínea de 0,6 a 1,0 gramas por litro de sangue e após uma refeição mista de 0,3 a 0,5 gramas por litro), da qualidade dos alimentos na luz dos órgãos, do período gasto para a ingestão da bebida, disposição metabólica, além de outros fatores 
físicos, biológicos e fisiológicos individuais (FORTES, 1975; LARINI e SALGADO, 1997).

Geralmente a absorção se completa entre 2 e 6 horas, contudo, a concentração plasmática máxima é atingida entre 30 e 90 minutos após a ingestão (FORTES, 1975; DELUCIA e OLIVEIRA, 2004).

Após ser absorvido pela circulação sanguínea as moléculas do álcool se difundem nos tecidos e fluidos corporais e, por serem hidrossolúveis, concentra-se em maior quantidade nos órgãos que contêm maior quantidade de água, em ordem decrescente no sangue e no cérebro, rins, pulmões, coração, intestinos, músculos esqueléticos e fígado, e com concentrações muito baixas em tecidos adiposos e ósseos (DELUCIA e OLIVEIRA, 2004). Contudo, a toxicocinética pode ser influenciada em função das variações individuais como conteúdo lipídico e aquoso, sexo, peso corporal e altura do indivíduo (LARINI e SALGADO, 1997).

O álcool que é absorvido no estômago e intestino delgado é conduzido pela veia porta, diretamente para o fígado onde é metabolizado. O excesso do álcool que é não é metabolizado pelo fígado é bombeado pelo coração para todo o organismo.

Segundo Larini e Salgado (1997) mais de 90\% do álcool é oxidado no fígado e somente cerca de 2 a 10\% do álcool absorvido são excretados inalterados pelos rins e pulmões, embora pequenas quantidades possam ser detectadas na saliva, esperma, suor e leite materno. A quantidade de álcool eliminado pelos pulmões pode ser verificada no teste do bafômetro que através da lei 9.503 de 23.09.1997 do Código de Trânsito Brasileiro, dá embasamento legal para punição de motoristas embriagados.

O álcool possui a capacidade de atravessar a placenta, atingindo a circulação fetal, podendo acarretar efeitos teratogênicos importantes no feto, caracterizados como síndrome alcoólica fetal (FORTES, 1975; MASTERS, 2003).

A oxidação do etanol no hepatócito é realizada através de três vias diferentes, sendo que cada uma se dá em um compartimento subcelular diferente (LARINI e SALGADO, 1997).

A primeira fase da biotransformação do álcool corresponde na conversão do etanol em aldeído acético, pela ação da enzima álcool desidrogenase (ADH) gástrica ou hepática presente no interior do compartimento citoplasmático (citossol). A enzima álcool desidrogenase pode também ser encontrada nos rins e mucosa intestinal (LARINI e SALGADO, 1997; DELUCIA e OLIVEIRA, 2004). 
Nesta etapa, ocorre a transferência de íons hidrogênio do álcool para o co-fator nicotinamida adenosina dinucleotídeo $\left(\mathrm{NAD}^{+}\right)$, formando NADH. A oxidação do etanol determina, assim, uma produção considerável de NADH e um aumento do steady state de NADH livre (LARINI e SALGADO, 1997; DELUCIA e OLIVEIRA, 2004). A produção excessiva de NADH parece estar subjacente a diversos distúrbios metabólicos ligados ao alcoolismo (MASTERS, 2003). Neste processo ocorre a seguinte reação:

$$
\mathrm{CH}_{3} \mathrm{CH}_{2} \mathrm{OH}+\mathrm{NAD}^{+} \stackrel{\mathrm{ADH}}{\longrightarrow} \mathrm{CH}_{3} \mathrm{CHO}+\mathrm{NADH}+\mathrm{H}^{+}
$$

O segundo passo da biotransformação do álcool em acetaldeído por oxidase do sistema citrocromo P450 dos microssomas hepáticos, ocorre no retículo endoplasmático, sendo, denominado sistema microssomal de oxidação do etanol (SMOE), também conhecido como sistema de oxidase de função mista, que utiliza o NADPH como co-fator do metabolismo do etanol, conforme a reação abaixo:

$$
\mathrm{CH}_{3} \mathrm{CH}_{2} \mathrm{OH}+\mathrm{NADPH}+\mathrm{H}^{+}+\mathrm{O}_{2} \longrightarrow \mathrm{CH}_{3} \mathrm{CHO}+\mathrm{NADP}^{+}+2 \mathrm{H}_{2} \mathrm{O}
$$

$\mathrm{Na}$ terceira etapa da biotransformação ocorre um processo oxidativo via catalase, no interior de peroxissoma. Inicialmente, ocorre a oxidação do NADPH através da NADPH-oxidase com a formação endógena de água oxigenada, que por sua vez promove a oxidação do etanol em aldeído, sendo o consumo de peróxido de hidrogênio pelo hepatócito a etapa limitante da atividade da catalase (LARINI e SALGADO, 1997; DELUCIA e OLIVEIRA, 2004). Neste processo as seguintes reações ocorrem:

$$
\begin{aligned}
& \mathrm{NADPH}+\mathrm{H}^{+}+\mathrm{O}_{2} \stackrel{\text { NAPH-oxidase }}{\longrightarrow} \mathrm{NADP}^{+}+\mathrm{H}_{2} \mathrm{O}_{2} \\
& \mathrm{H}_{2} \mathrm{O}_{2}+\mathrm{CH}_{3} \mathrm{CH}_{2} \mathrm{OH} \stackrel{\text { catalase }}{\longrightarrow} 2 \mathrm{H}_{2} \mathrm{O}+\mathrm{CH}_{3} \mathrm{CHO}
\end{aligned}
$$


O produto final formado nas três vias citadas acima é o aldeído acético que é uma substância altamente tóxica, sendo rapidamente convertido em acetato por ação da enzima aldeído desidrogenase e acetil-coenzima A. A acetil-coenzima A participa do ciclo de Kebrs, sendo convertida em $\mathrm{CO}_{2}$ e $\mathrm{H}_{2} \mathrm{O}$ ou é utilizada em reações anabólicas envolvidas na síntese de colesterol e triglicérides, dos ácidos graxos e de outros constituintes dos tecidos, dando assim condições para que ocorra esteatose hepática. (LARINI e SALGADO, 1997; MASTERS, 2004; DELUCIA e OLIVEIRA, 2004).

A figura 01 demonstra os caminhos que o etanol pode seguir dentro do hepatócito.

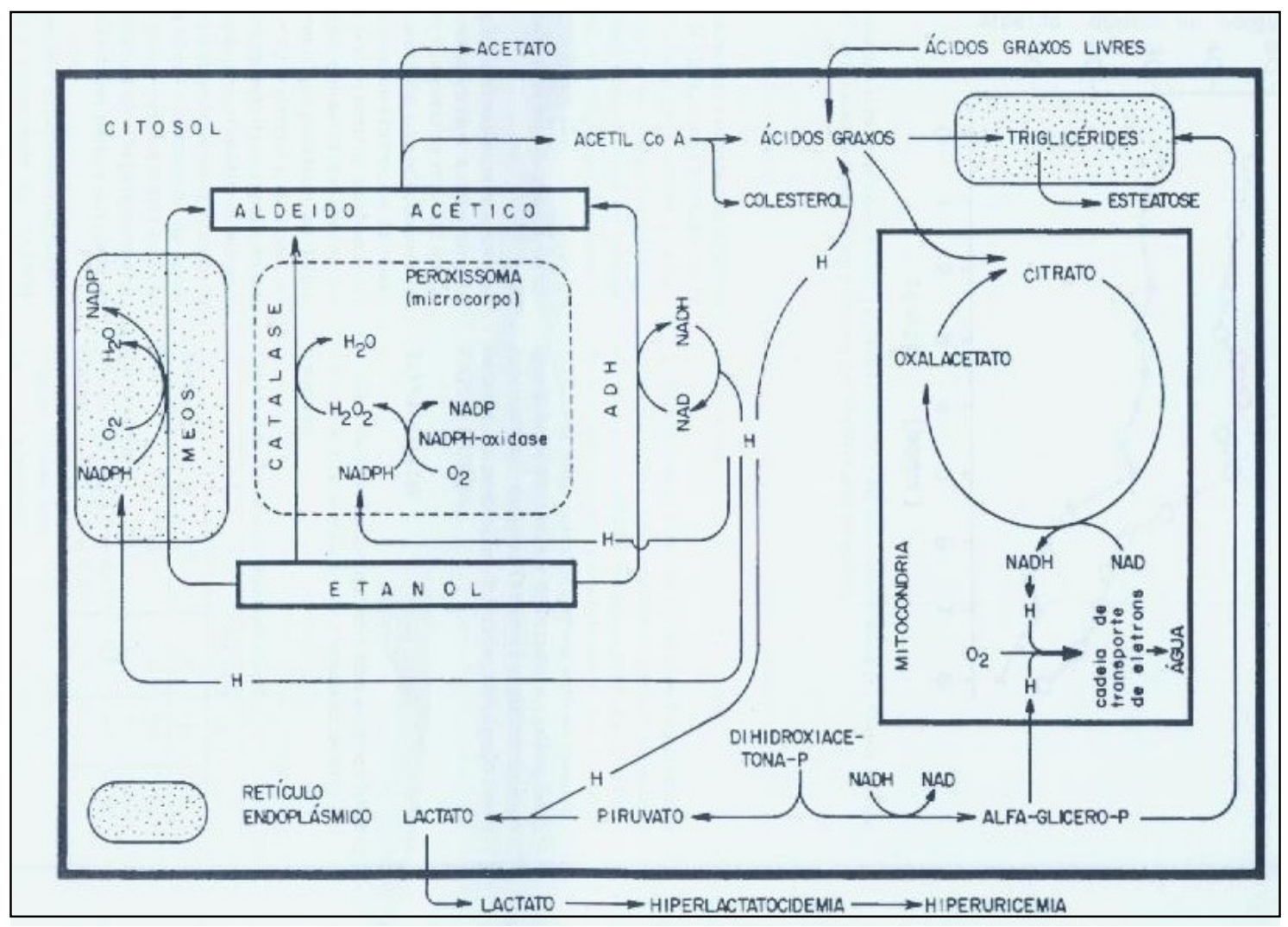

Figura 01. Circuito de Biotransformação do Álcool (LARINI e SALGADO, 1997). 


\section{TECIDO MUSCULAR}

Segundo GARTNER \& HIATT (1997), o tecido muscular é constituído por células alongadas, com grande quantidade de filamentos citoplasmáticos, responsáveis pela contração muscular e conseqüentemente pelos movimentos corporais.

São denominadas estriadas ou lisas dependendo, respectivamente, da presença ou ausência de um arranjo de proteínas contráteis miofibrilares, os miofilamentos, que se repetem regularmente.

As células musculares, como todo o tecido de sustentação possuem origem mesodérmica, como pode ser observado na figura 03 .

\subsection{Características Morfológicas e Funcionais dos Músculos}

O tecido muscular dos mamíferos pode ser dividido em três tipos: o músculo liso, o músculo estriado cardíaco e o músculo estriado esquelético, cada um apresenta suas características morfológicas e funcionais próprias, como pode se observar na figura 02.

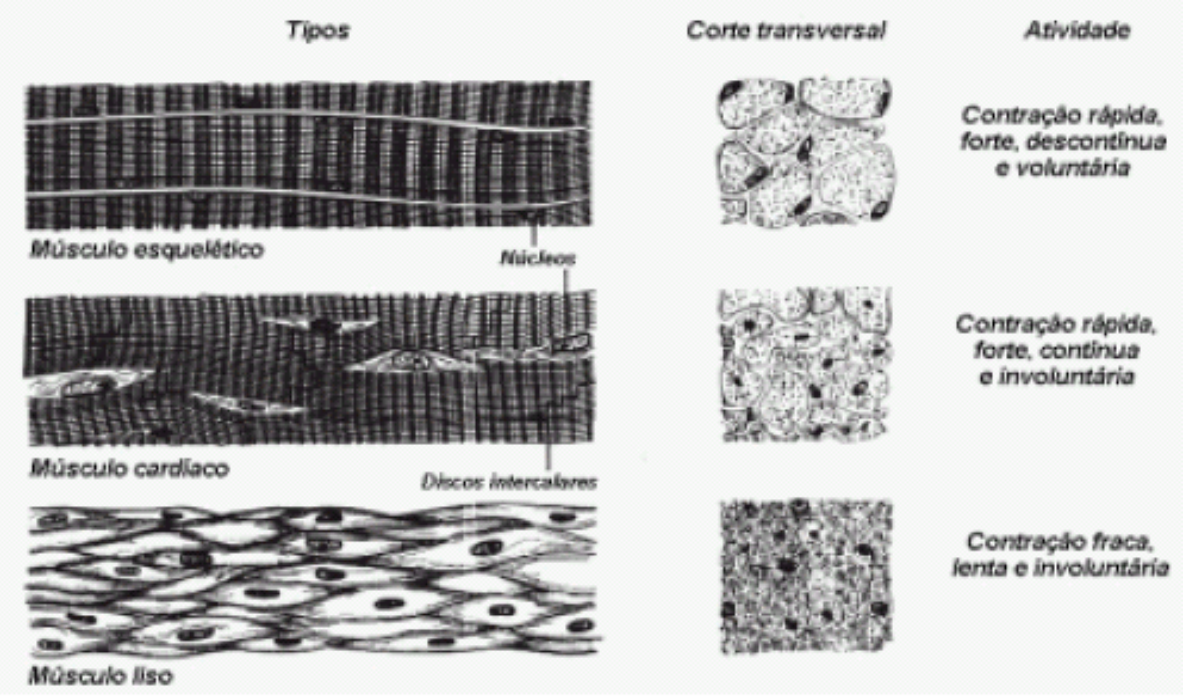

Figura 02. Tipos de Músculos (JUNQUEIRA \& CARNEIRO, 1999). 
O músculo liso é assim denominado por não apresentar estrias transversais, é formado por aglomerados de células fusiformes, mononucleadas, cujo tamanho varia consideravelmente dependendo de sua localização, podendo ser encontrado nas paredes dos vasos sanguíneos e nas vísceras. Este tipo de músculo apresenta processo de contração lento, porém mais freqüentes, ritmadas e intermitente, não estando sujeito ao controle voluntário.

O músculo estriado esquelético leva este nome por possuir estriações transversais, é formado por feixes de células cilíndricas muito longas e multinucleadas que apresentam contração rápida, vigorosa e voluntária.

O músculo cardíaco ou miocárdio, como o próprio nome diz, é encontrado no coração. Este tipo de musculatura possui estrias transversais como o músculo esquelético, sendo formado de células alongadas e ramificadas, que se unem por intermédio dos discos intercalares (estrutura específica do músculo cardíaco) e apresenta contração involuntária, vigorosa e rítmica (GARTNER \& HIATT, 1997; JUNQUEIRA \& CARNEIRO, 1999).

\subsection{Estrutura Macroscópica do Músculo Estriado Esquelético}

As fibras musculares são provenientes de células precursoras miogênicas chamadas mioblastos que se proliferam, fundem-se para formar os miotubos e finalmente se diferenciam em fibras musculares (WILLIANS et al 1995; JUNQUEIRA \& CARNEIRO, 1999).

Segundo MALTIN et al. (1983), miotubo é um sincício, ou seja, célula gerada pela fusão de duas ou mais células, através do desaparecimento das paredes contíguas, no qual os núcleos são normalmente arranjados em uma cadeia central.

Os músculos esqueléticos são compostos de células musculares cilíndricas denominadas fibras musculares organizadas em feixes com até 150 fibras, sendo que cada feixe é denominado de fascículo. Os fascículos são envolvidos por um tecido conjuntivo, chamado epimísio. Do epimísio partem septos muito finos de tecido conjuntivo denominado perimísio, que se dirigem para o interior do músculo, separando e envolvendo cada feixe de fibra muscular. Por sua vez, cada fibra muscular é separada das fibras vizinhas, por uma camada muito fina constituída pela lâmina basal da fibra muscular e por fibras reticulares do endomísio (FOX \& MATHEWS, 1986; McARDLE 
et al, 1991; SMITH et al, 1997; MARZZOCO e TORRES, 1999; POWERS e HOWLEY, 2000; GUYTON e HALL, 2002).

O tecido conjuntivo encontrado no tecido muscular possui grande importância funcional, uma vez que tem a função de manter as fibras musculares unidas e permitir que a força de contração gerada por cada fibra individualmente atue sobre o músculo como um todo.

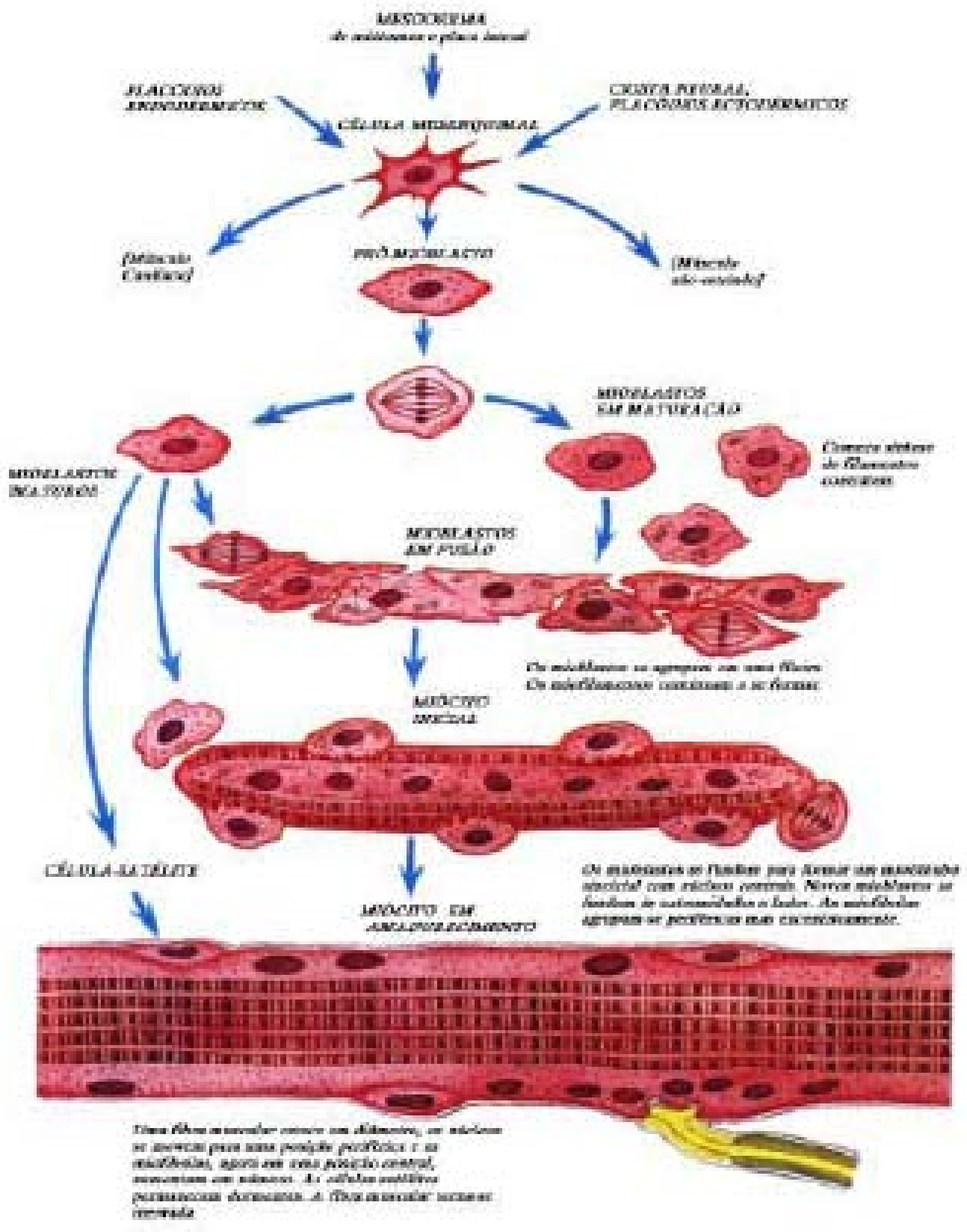

Figura 03. Esquema da origem embrionária do músculo esquelético (WILLIANS et al., 1995). 
Cada fibra muscular é envolvida por uma membrana celular fina e elástica chamada sarcolema, constituído por uma fina camada de material polissacarídeo que contém inúmeras fibrilas colágenas. Abaixo desta encontra-se o protoplasma ou sarcoplasma, citoplasma da célula muscular, composto de uma substância gelatinosa e inúmeras estruturas importantes como várias organelas celulares especializadas, proteínas contráteis, enzimas, partículas de gordura e glicogênio, estando quase completamente preenchido por fibrilas paralelas, as miofibrilas. Dentro do sarcoplasma, encontra-se uma extensa rede entrelaçada de canais túbulos e vesículas, que correm paralelamente a cada miofibrilas, conhecidos como retículo sarcoplasmático, que armazena cálcio, o qual é importante para a contração muscular. Outro conjunto de canais membranosos denominados túbulos transversos (ou, simplesmente, túbulos T) se estende para o interior do sarcolema e passam completamente pela fibra e por entre duas porções alargadas chamadas cisternas terminais. Estes sistemas altamente especializados proporcionam à célula sua integridade estrutural e também desempenha importantes funções na contração muscular (FOX \& MATHEWS, 1986; McARDLE et al, 1991; SMITH et al, 1997; GARTNER \& HIATT, 1997; JUNQUEIRA \& CARNEIRO, 1997; MARZZOCO e TORRES, 1999; POWERS e HOWLEY, 2000; GUYTON e HALL, 2002).

A figura 04 esquematiza as estruturas citas acima, como sarcolema, miofibrilas, retículo sarcoplasmático, entre outros.

As fibras musculares esqueléticas apresentam vários núcleos, situados na periferia da célula, sob o sarcolema e é fartamente irrigado por uma rica rede capilares que correm entre as fibras, provenientes dos vasos sangüíneos que penetram no músculo através dos septos do tecido conjuntivo (JUNQUEIRA \& CARNEIRO, 1999).

Segundo McARDLE et al (1991), a circulação capilar possui, além de seu papel no fornecimento de oxigênio, nutrientes e hormônios, esta também proporciona meios para remover o calor e os co-produtos metabólicos dos tecidos ativos. 


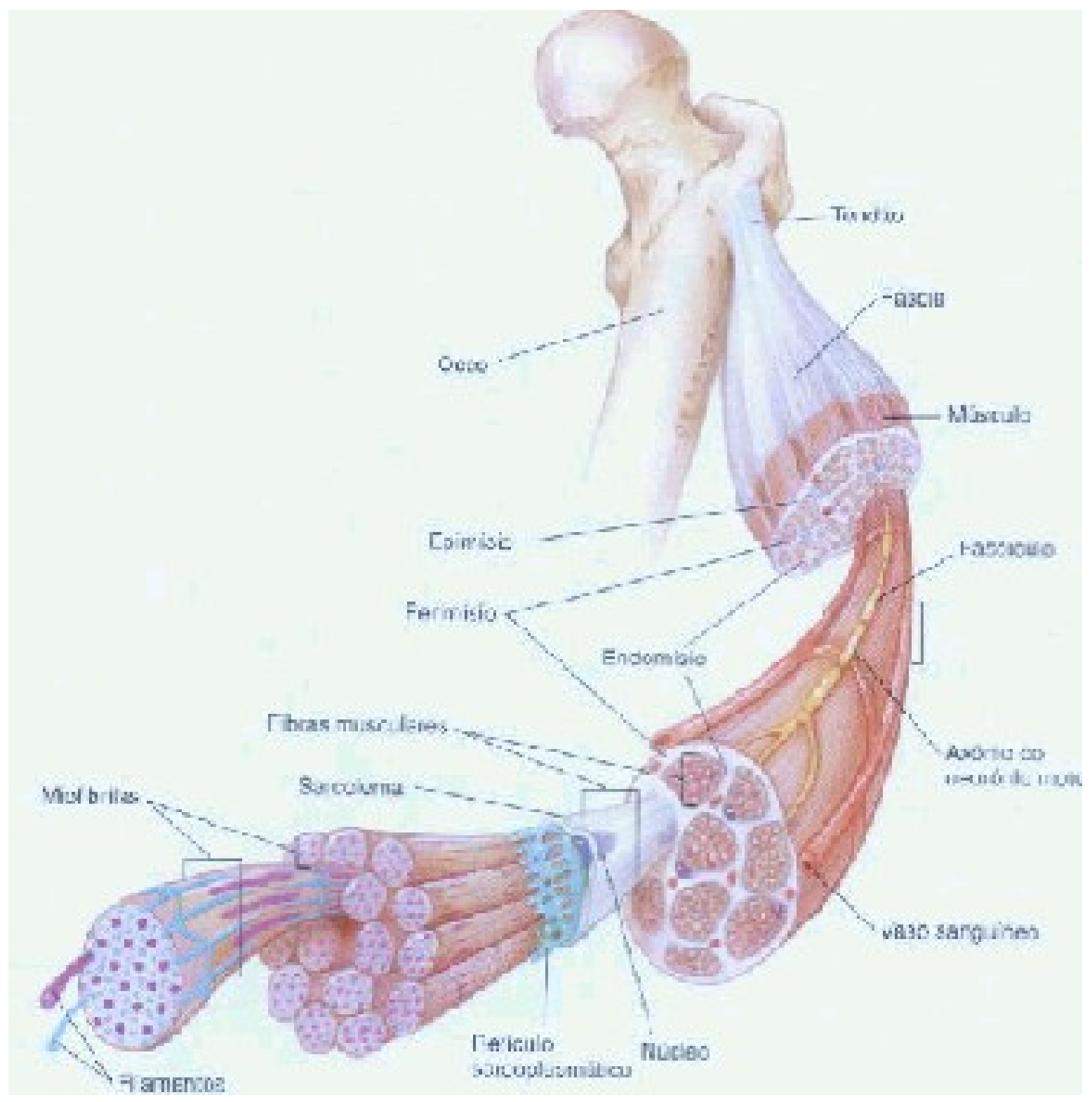

Figura 04. Tecido conjuntivo que envolve o músculo esquelético (POWERS e HOWLEY, 2000). 


\subsection{Ultra-Estrutura do Músculo Estriado Esquelético}

Os miofilamentos que compreendem as miofibrilas, por sua vez são agrupadas para formar as fibras musculares, que possuem comprimento variável de poucos milímetros $(\mathrm{mm})$ a alguns centímetros $(\mathrm{cm})$ e diâmetro individual de 50 a 100 micrômetros $(\mu \mathrm{m})(\mathrm{SMITH}$ et al, 1997).

As miofibrilas contratéis são numerosas estruturas fusiformes, composta de unidades que se repetem denominadas sarcômeros. Cada sarcômero, por sua vez, é limitado consecutivamente por uma fina camada de proteínas estruturais chamadas linhas Z (a letra Z provém do alemão zwischen, que significa “entre"). A região do sarcômero entre duas linhas $Z$ sucessivas apresenta $2,5 \mu \mathrm{m}$ de comprimento e é considerada a unidade funcional do músculo esquelético. Devido às repetições dos sarcômeros, as miofibrilas apresentam estriações transversais (motivo que leva o músculo esquelético ser chamado de músculo "estriado"), com alternância de faixas claras e escuras. A faixa escura (anisotrópica) recebe o nome de banda A, enquanto a faixa clara (isotrópica), banda I. No centro da cada banda I aparece uma linha mais escura, a linha $\mathrm{Z}$ muscular. $\mathrm{O}$ centro da banda $\mathrm{A}$ contém a zona $\mathrm{H}$, região que não apresenta actina, e é dividida em duas partes iguais pela linha $\mathrm{M}$, que delineia o centro do sarcômero e apóiam o arranjo dos filamentos de miosina (FOX \& MATHEWS, 1986; McARDLE et al, 1991; SMITH et al, 1997; GARTNER \& HIATT, 1997; JUNQUEIRA \& CARNEIRO, 1997; POWERS e HOWLEY, 2000; GUYTON e HALL, 2002).

Cada miofibrila, em geral, são compostas por dois importantes filamentos protéicos: 1.500 filamentos espessos, formados de miosina e 3.000 filamentos finos, formados por actina.

Os filamentos de actina inserem-se nas linhas $\mathrm{Z}$ graças à participação de uma proteína, a $\alpha$-actinina, que se dirige medialmente, porém não atinge o centro do sarcômero. Esse filamentos finos são constituídos, sobretudo por monômeros globosos (G-actina), que se polimerizam em cadeias que se enrolam em dupla hélice (F-actina), à qual se associam as proteínas tropomiosina e troponina (molécula composta de três polipeptídeos globulares, TnC, TnT e TnI). 
A tropomiosina é uma molécula que se localiza sobre o filamento de actina e as moléculas de troponina ficam engatadas na extremidade das moléculas de tropomiosina muscular (FOX \& MATHEWS, 1986; SMITH et al, 1997; GARTNER \& HIATT, 1997; POWERS e HOWLEY, 2000; GUYTON e HALL, 2002).

Os filamentos espessos de miosina ficam situados no centro do sarcômero, sem atingirem lateralmente as linhas Z. Cada molécula de miosina é constituída por dois longos polipeptídeos entrelaçados que assumem a forma de um bastão longo com duas cabeças globulares nas extremidades, que combinam especificamente com a actina, através de projeções protéicas que se estendem na direção dos filamentos de actina denominadas pontes cruzadas (FOX \& MATHEWS, 1986; JUNQUEIRA \& CARNEIRO, 1997).

Em certas condições, a molécula de miosina pode ser cindida em dois fragmentos, um com o dobro do peso do outro. O fragmento mais leve (meromiosina leve) é um bastão reto responsável pelas propriedades de auto-agregação da miosina e o fragmento mais pesado (meromiosina pesada), se parece com a ponta de um bastão de hóquei, exibe qualidades semelhantes à enzima trifosfatase de adenosina (ATPase), capaz de decompor adenosina trifosfato (ATP) em adenosina difosfato (ADP), fosfato inorgânico $\left(\mathrm{P}_{\mathrm{i}}\right)$ mais energia ( $\Delta \mathrm{G}$ 7,3 Kcal / mol) (LEHNINGER, 1984; SMITH et al, 1997; GARTNER \& HIATT, 1997; MARZZOCO e TORRES, 1999).

A relação látero-lateral entre os filamentos de actina e miosina é difícil de ser mantido, sendo somente conseguido graças a um grande número de moléculas filamentosas de proteína denominado titina. A titina é uma das maiores moléculas protéicas do corpo, com peso molecular de, aproximadamente, 3.000.000. Essa molécula elástica atua como arcabouço, que reveste os filamentos de miosina e actina, a fim de produzir a contração do sarcômero, além disso, existem razões para crer que a própria molécula de titina atue como modelo para a formação inicial de porções dos filamentos contráteis do sarcômero, especialmente os filamentos de miosina (GUYTON e HALL, 2002).

A figura 05 demonstra através de um esquema ilustrativo a microestrutura do tecido muscular. 


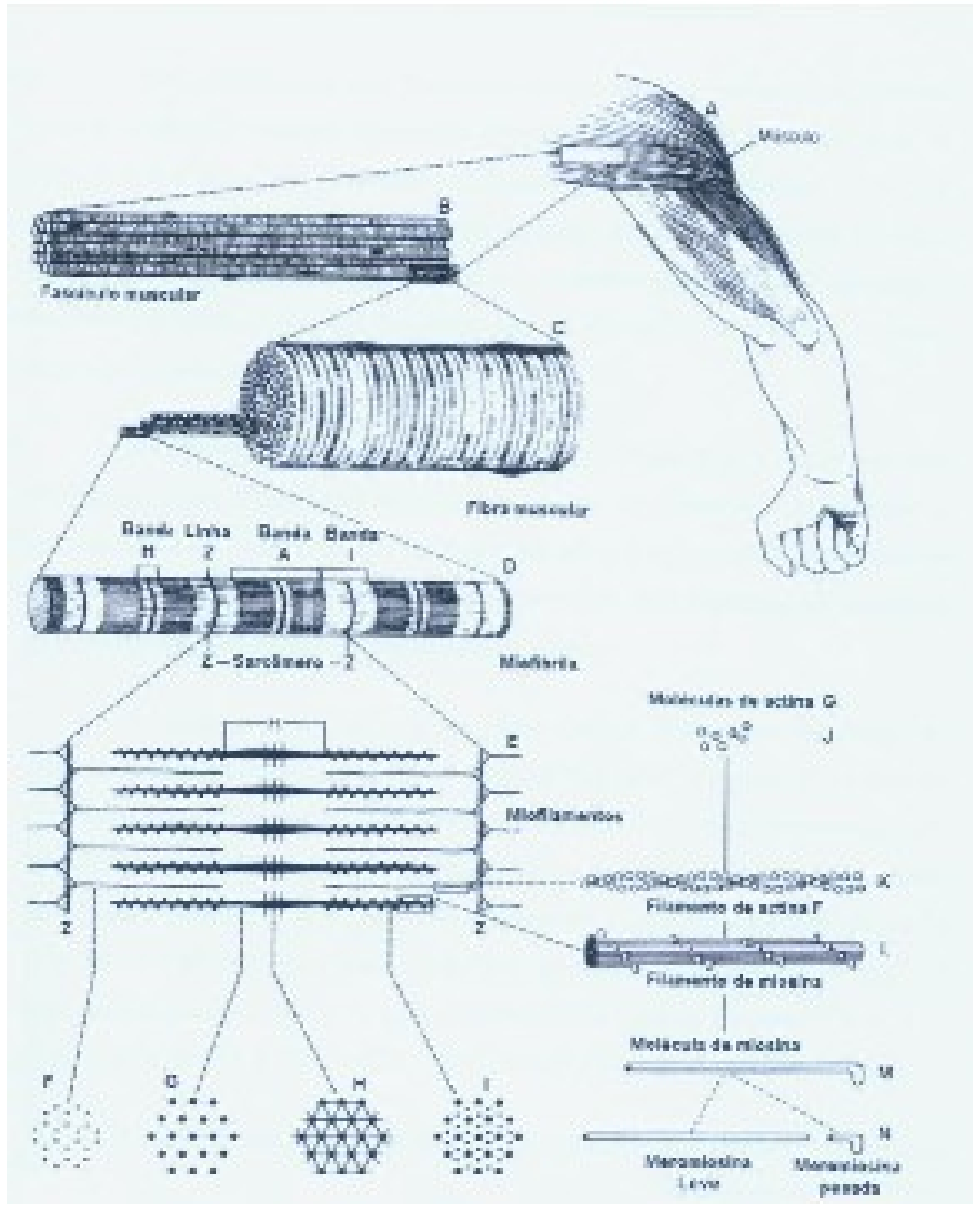

Figura 05. Esquema ilustrativo da microestrutura muscular (JUNQUEIRA \& CARNEIRO, 1999). 


\subsection{Mecanismo Geral de Contração Muscular e a Teoria do Filamento Deslizante}

A contração muscular tem início quando um potencial de ação dirige-se ao longo de um nervo motor até suas terminações nas fibras musculares, onde em cada terminação, o nervo secreta pequena quantidade de substância neurotransmissora, acetilcolina, que atua sobre a membrana da fibra muscular abrindo os canais regulados pela acetilcolina, provocando assim a entrada de grande quantidade de íons sódio para o interior da membrana da fibra muscular, desencadeando um potencial de ação na fibra que se propaga e despolariza a fibra muscular, induzindo o retículo sarcoplasmático liberar grande quantidade de íons cálcio, que geram forças atrativas entre os filamentos de actina e de miosina, fazendo com que estes deslizem um sobre o outro (GUYTON e HALL, 2002).

A cabeça globular da ponte cruzada de miosina proporciona o meio mecânico para que os filamentos de actina e miosina deslizem uns sobre os outros, como demonstrado na figura 06.

$\mathrm{O}$ conceito de que os filamentos de actina e miosina deslizam durante a contração muscular é denominada teoria dos filamentos deslizantes da contração muscular (SMITH et al, 1997).

Durante a contração, as linhas Z são essencialmente tracionadas para o centro de cada sarcômero, a banda I torna-se mais estreita, a banda A não se altera e a zona $\mathrm{H}$ pode desaparecer quando os filamentos de actina entram em contato no centro do sarcômero (FOX \& MATHEWS, 1986; SMITH et al, 1997; GARTNER \& HIATT, 1997; POWERS e HOWLEY, 2000; GUYTON e HALL, 2002).

O ciclo de contração se rompe quando os potenciais de ação são interrompidos, o cálcio é removido do sarcoplasma e bombeado para o interior do retículo sarcoplasmático pela bomba de cálcio, isso faz com que os sítios ativos da actina e o músculo relaxar (POWERS e HOWLEY, 2000). 


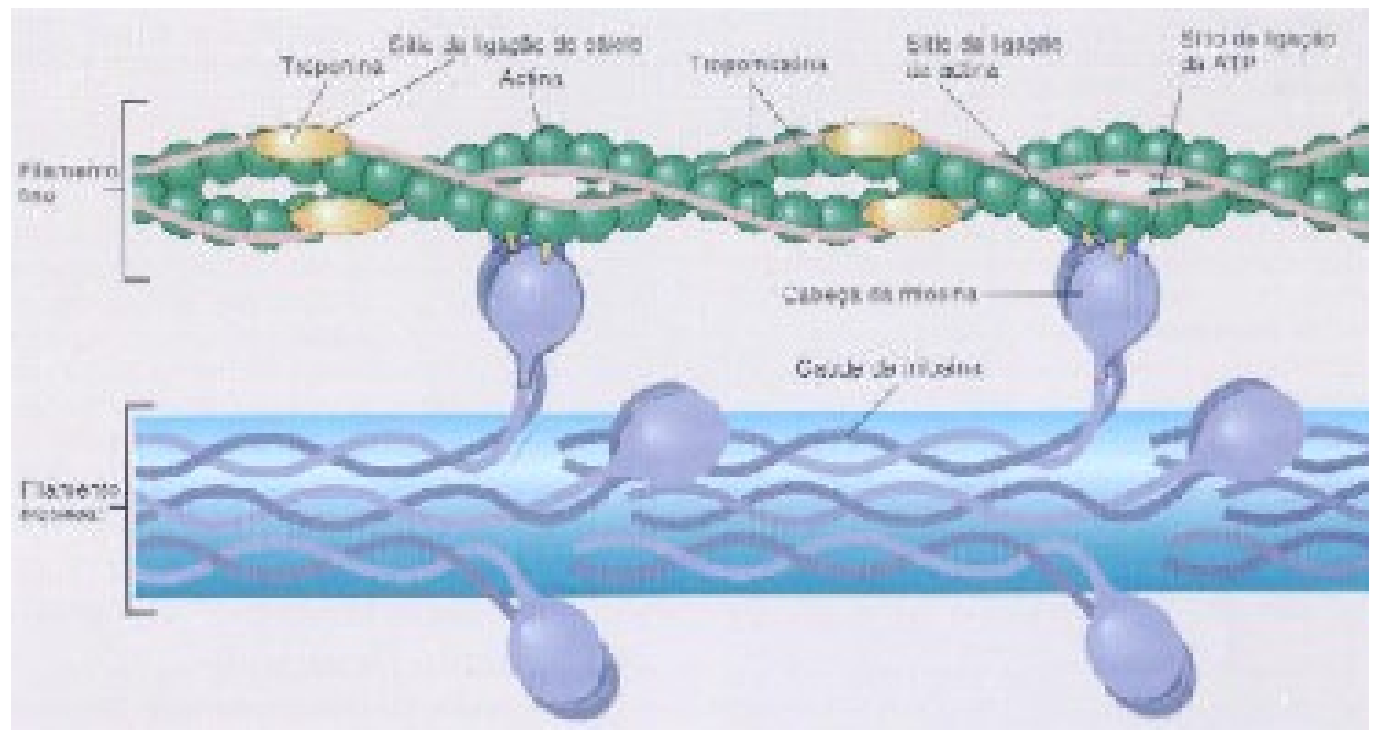

Figura 06. Relação entre a troponina, tropomiosina, as pontes cruzadas da miosina e o cálcio (POWERS e HOWLEY, 2000).

\subsection{Tipos de Fibras Musculares}

O músculo esquelético não é um grupo homogêneo de fibras, este pode ser dividido em várias classes com base nas suas características anatômicas, histoquímicas ou bioquímicas das fibras individuais.

O componente da molécula de miosina, a cadeia pesada, determina as características funcionais da fibra muscular.

O músculo esquelético humano apresenta três tipos de fibras musculares, divididas em dois subtipos, a fibra lenta - tipo I (fibras vermelhas) e a fibra rápida tipo IIa e IIb (fibras brancas). No entanto, pesquisas recentes têm demonstrado evidências da presença de duas novas fibras musculares em ratos, a tipo IId ou IIx (fibra rápida) e a tipo Ia (fibra lenta) e que possivelmente o músculo humano apresente em torno de seis tipos de fibras musculares (I, IC, IIAC, IIA, IIAB, e IIB) (POWERS e HOWLEY, 2000; MARZZOCO e TORRES, 1999; SMITH et al, 1997; FRY et al, 1994).

Segundo McARDLE et al (1991), a fibra IIc normalmente é uma fibra rara e indiferenciada que pode participar na reinervação ou na transformação das unidades motoras.

Contudo, para a finalidade deste trabalho somente será abordado os três tipos principais de fibras musculares, a fibra tipo I, IIa e IIb. 
As fibras de tipo I, vermelhas, também são designadas de fibras de contração lenta ou oxidativa lenta (OL), contêm muitas enzimas oxidativas devido ao grande número de mitocôndrias, apresentam baixo nível de atividade de miosina ATPase, são envolvidas por inúmeros capilares e possuem uma alta concentração de mioglobina e outras hemoproteínas, o que confere a este tipo de fibra a cor avermelhada, a alta capacidade metabólica aeróbica e maior resistência à fadiga, sendo assim bem apropriadas para o exercício aeróbico prolongado.

As fibras rápidas ou brancas são mais claras por serem praticamente destituídas de mioglobina e conterem poucas mitocôndrias.

O primeiro tipo de fibra rápida é a fibra tipo IIb, também chamada de fibra glicolítica rápida (GR), que apresenta um número pequeno de mitocôndrias, uma capacidade limitada de metabolismo aeróbico e menor resistência à fadiga que a fibra tipo I, contudo, este tipo de fibra é rico em enzimas glicolíticas, as quais lhe provêem uma grande capacidade anaeróbica.

O segundo tipo de fibra rápida é a fibra tipo IIa, conhecida também por fibra glicolítica oxidativa rápida $(\mathrm{ORG})$ ou ainda por fibra intermediária, pois apresenta um valor intermediário de características como número de mitocôndrias, tamanho, velocidade de contração, velocidade de fadiga, entre a fibra tipo I e a fibra tipo IIb e devido a este fato este tipo de fibra é extremamente adaptável com o treinamento.

Em relação às propriedades contráteis, as fibras tipo I apresentam uma velocidade máxima de encurtamento (Vmáx) mais lenta em comparação com as fibras rápidas, principalmente em relação à fibra tipo IIb, que possui uma maior atividade da ATPase da miosina, resultando na maior Vmáx de todos os tipos de fibra. Além disso, a fibra tipo I parece produzir uma menor tensão específica em comparação com as fibras rápidas (POWERS e HOWLEY, 2000; MARZZOCO e TORRES, 1999; SMITH et al, 1997).

A tabela 01 demonstra as características das fibras musculares esqueléticas baseadas em suas propriedades físicas e metabólicas. 
Tabela 01. Características das fibras musculares esqueléticas baseadas nas propriedades físicas e metabólicas (POWERS e HOWLEY, 2000).

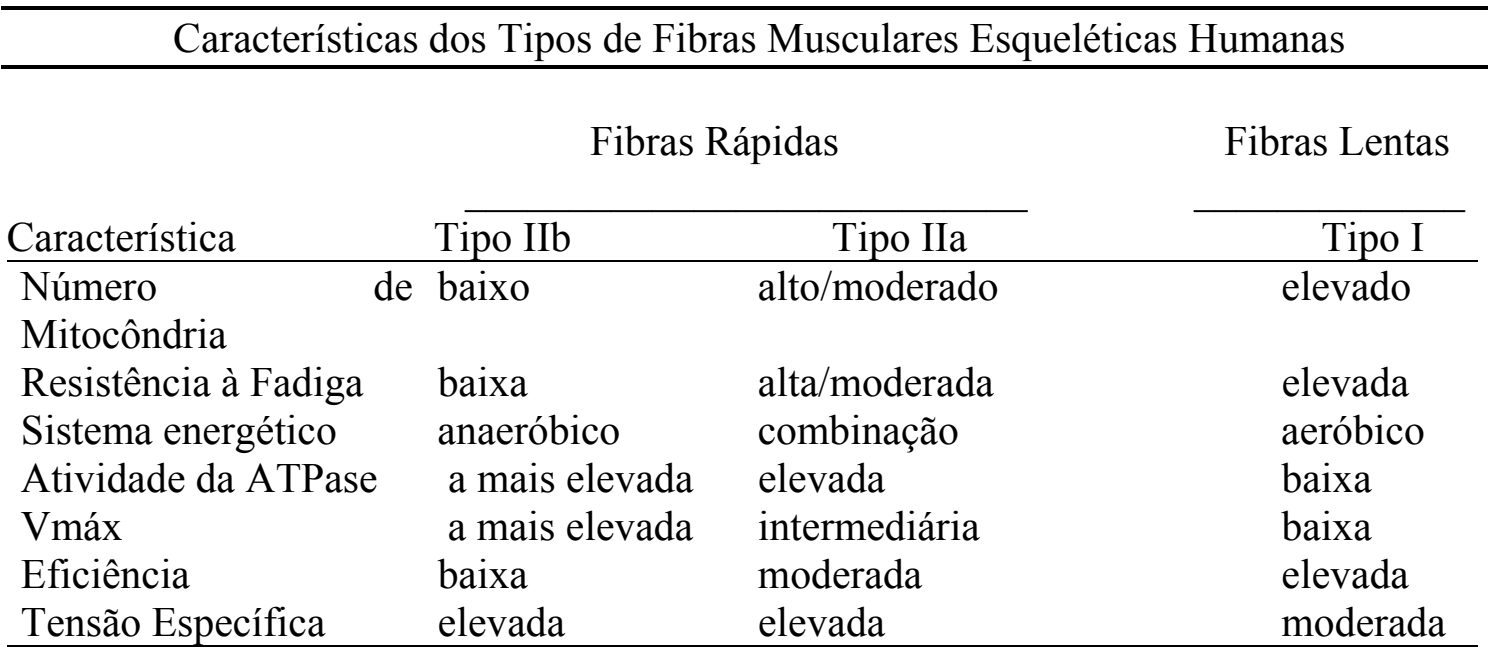

Diversos estudos têm demonstrado que a porcentagem de fibras musculares tipo I e II podem variar de indivíduo para indivíduo, dependendo da genética e do treinamento realizado, mas que independe do sexo e da idade. Indivíduos sedentários apresentam cerca de $47-53 \%$ de fibras do tipo I, lentas, em contra posição indivíduos que realizam treinamento de potência, como por exemplo, corredores de curta distância, possuem grande porcentagem de fibras rápidas (70-75\%), enquanto, os de endurance (corrida de longa distância) geralmente apresentam grande porcentagem de fibras lentas (70-80\%) (POWERS e HOWLEY, 2000).

Segundo, ABERNETHY et al (1990), com o estudo das alterações das isoformas da miosina, podemos verificar as alterações no tipo de fibra, ou seja, transição entre as fibras rápidas com as fibras lentas, vice-versa, de acordo com o exercício físico executado, por exemplo, o treinamento de corrida de curta distância diminui a proporção de fibras tipo I e aumenta significantemente a proporção de fibras tipo IIa, enquanto, o treinamento de resistência leva a uma redução da porcentagem de fibras tipo IIb e um aumento na fibra tipo IIa, demonstrando desta forma que a transição ocorre de forma gradual, e na seguinte ordem tipo IIb $\rightarrow$ IIa $\leftarrow$ I .

Contudo, segundo McARDLE et al (1991) e GUYTON e HALL (2002), ainda é necessário realizar muitas pesquisas sobre nesta área de possibilidades de mudanças bioquímicas- fisiológicas das fibras musculares (plasticidade muscular), com 
transformação progressiva do tipo de fibra após um treinamento específico e de longa duração, bem como a relação a herança hereditária.

As fibras musculares ainda podem sofrer dois outros processos que levam a modificação do tecido quando submetidas ao treinamento físico: hipertrofia (processo caracterizado pelo aumento do volume da célula), e hiperplasia (crescimento devido à proliferação das células por multiplicação miótica) (JUNQUEIRA \& CARNEIRO, 1999). A ausência de atividade de um determinado músculo pode levar a atrofia do mesmo, ou seja, a diminuição na massa muscular.

\subsection{O Alcoolismo e os Sistemas Orgânicos}

A ação do álcool sobre os sistemas orgânicos como sistema nervoso, sistema digestório e anexos, sistema circulatório e sistema músculo esquelético é complexo e traz consigo inúmeros problemas decorrentes da ingestão freqüente e excessiva de álcool (VILA et al., 2001; ADACHI et al., 2003).

A doença muscular induzida pelo álcool (AIMD) é um termo composto para descrever qualquer patologia (molecular, bioquímica, estrutural, ou fisiológica) que afete o músculo como conseqüência da ingestão aguda ou crônica de álcool (PREDDY et al., 2001b, 2002), podendo ser conseqüência de neuropatia motora, doença muscular esquelética ou má nutrição profunda de proteína-caloria (PREEDY et al., 2002).

A AIMD geralmente é ignorada dentre os demais distúrbios conseqüentes do alcoolismo, contudo as AIMDs afetam $40-60 \%$ dos alcoólatras, sendo mais comum do que outras patologias induzidas pelo álcool, como: cirrose (15-20\% dos alcoólatras crônicos), neuropatias periféricas (15-20\%), doenças intestinais (30-50\%) ou cardiomiopatias ( 15-35\%) (PREEDY et al., 2003).

Segundo PREEDY et al. (2001b, 2002), miopatia alcoólica pode ser subdividida em duas formas:

A miopatia alcoólica aguda, que é uma condição rara, afetando aproximadamente $1 \%$ dos alcoólatras, sendo caracterizada por dor muscular inflamatória, usualmente com mioglobinuria, causadas pela atividade do soro da creatina quinase e freqüente lesão renal. Isto ocorre se o alcoólatra sofrer de subnutrição e afeta ambas as fibras musculares, vermelha e branca. 
E a miopatia alcoólica crônica, é uma complicação freqüente do alcoolismo afetando aproximadamente $50 \%$ dos pacientes. Primeiramente afeta fibras musculares brancas do peitoral e a cintura pélvica, isto é, "miopatia metabólica proximal" embora outros grupos musculares possam ser afetados. Aproximadamente $50 \%$ dos pacientes afetados mostram fraqueza muscular proximal não estando esta condição associada com deficiência nutricional, vitamínica ou mineral. A atrofia das fibras musculares não conduz a um aumento na creatina quinase e é reversível após 6-12 meses de abstinência.

A miopatia é reversível primeiramente com a abstinência, mas um suporte nutricinal e a reabilitação facilitam a reconversão do processo (PREEDY et al., 2003), porém a recuperação da força muscular é incompleta (PREEDY et al., 2001b).

Estudos têm demonstrado que 1 ou 2 terços dos alcoólatras crônicos apresentam miopatia alcoólica (FARIS et al, 1967; WORDEN, 1976; MARTIN et al, 1985; TROUNCE et al, 1987).

A forma crônica da AIMD é argumentável como a mais prevalente desordem esquelética no Hemisfério Oeste, afetando mais de $2 \%$ da população, sendo desta forma mais comum do que as miopatias hereditárias como a distrofia muscular de Becker e de Duchenne (2-30\%).

O ponto importante da miopatia alcoólica não é a debilidade do fígado, a neuropatia ou a desnutrição, ainda que possam ocorrer ao longo da miopatia alcoólica e em alguns indivíduos sobreporem-se às múltiplas lesões. Entretanto, os radicais livres podem estar envolvidos na patogênese de cada lesão (PREEDY et al., 2003).

A miopatia alcoólica é caracterizada por atrofia seletiva da fibra muscular do tipo II (glicolítica, rápida, anaeróbica) (MASTAGLIA \& WALTON, 1982), porém, o subtipo tipo IIb (o qual tem pouco ou não mitocôndrias) são particularmente afetadas em contraste com as fibras tipo IIa e fibra tipo I (oxidativa, lenta, aeróbica), contudo, a patogênese desta atrofia ainda é desconhecida. FERNÁNDEZ-SOLÁ et al.(1995), atribuem esta atrofia a diversas causas, como redução da atividade mecânica do músculo esquelético, caquexia, denervação, disfunções endócrinas (assim como terapia com esteróide) e diversas miopatias estruturais e metabólicas. 
Cerca de 30-50\% dos alcoólatras crônicos apresentam redução seletiva da fibra tipo II (HUDSON, 1984; SLAVIN et al., 1983), entretanto as fibras tipo I são relativamente protegidas e podem apresentar uma hipertrofia compensatória no estágio inicial da doença (PREEDY \& PETERS, 1990; FERNÁNDEZ-SOLÁ et al., 1995; PREEDY et al., 2001a; WORRALL et al., 2001), podendo também apresentar uma atrofia quando há exposição severa ao álcool (ADACHI et al., 2003).

PREEDY (2003), em seu estudo demonstra evidências que a lesão miopatica é resultante por deficiência central na síntese da proteína muscular.

Uma variedade de lesões bioquímicas ocorrem no músculo esquelético como resultado da ingestão de etanol, dentre elas estão, alterações na membrana muscular; aumento nos níveis da atividade do $\mathrm{NA}^{+}-\mathrm{K}^{+}$-ATPase; falha no transporte $\mathrm{e}$ armazenamento de cálcio; dilatação do retículo sarcoplasmático (WORRALL et al., 2001; ADACHI et al., 2003); mudanças no status dos radicais livres (PREEDY et al., 2002); alteração no metabolismo dos carboidratos e dos lipídeos; resistência à insulina; alteração na síntese de proteínas (PREEDY et al., 2001a); entre outras.

Déficit de contratilidade, fraqueza, dificuldade de caminhar ou locomoção, quedas freqüentes são decorrentes da redução da força e da massa muscular características comum do alcoólatra crônico (PREEDY et al., 2002), havendo uma relação entre a perda da força muscular e o tempo de consumo do etanol (PREEDY et al., 2001a; WORRALL et al., 2001).

A medida das fibras musculares através de biopsia é considerada o melhor processo para identificação da miopatia alcoólica, bem como as variáveis correlatas, como redução da excreção da creatinina na urina ou proporção muscular de proteína/DNA ou RNA/DNA (PREEDY et al., 2001b).

PREEDY et al. (1994) estudaram a relação entre a miopatia alcoólica e as alterações na transcrição (síntese de RNA sobre um molde de DNA) e na tradução (síntese de uma molécula protéica sob o comando da informação contida na molécula de RNA mensageiro) e demonstram que no alcoolismo crônico faz com que haja uma rápida e sustentável perda de ribossomos. 


\subsection{Regeneração do Tecido Muscular}

Os três tipos de tecido muscular exibem diferenças em sua capacidade regenerativa após uma lesão parcial. O músculo cardíaco não se regenera, por exemplo, após um infarto do miocárdio, partes do músculo que foram destruídas são invadidas por fibroblastos que produzem fibras colágenas, formando no local uma cicatriz de tecido conjuntivo denso; já o tecido muscular liso é capaz de apresentar uma resposta regenerativa eficiente, pois após a lesão, as células musculares lisas que permaneceram viáveis entram em mitose e reparam o tecido destruído (JUNQUEIRA \& CARNEIRO, 1999).

O processo de reparo muscular tem sido descrito desde o final do século XIX, mas somente nos últimos trinta anos, foi realmente estabelecida à capacidade regenerativa das fibras musculares esqueléticas (CARLSON \& FAULKNER, 1983).

As lesões musculares mais comuns estão relacionadas ao aparelho locomotor, ocorrendo tanto em atletas de elite, bem como em atletas de final de semana e até mesmo em sedentários (CRISCO et al, 1994).

No músculo esquelético, a regeneração dependerá da extensão da lesão, quando a regeneração pode não ocorrer, sendo o tecido lesado substituído por um tecido conjuntivo ou fibrose. Contudo, os músculos esqueléticos apresentam uma capacidade de reconstrução, embora, os núcleos de suas fibras não se dividam. Admite-se que a responsável por esta habilidade de reconstrução reside nas células precursoras, conhecidas como células satélites (CS), inicialmente descritas em 1961, que são capazes de migrar para o interior da célula.

As células satélites são células, mononucleadas, indiferenciadas, dispostas paralelamente às fibras musculares, entre a lâmina basal que envolve as fibras e o sarcolema das fibras musculares maduras, podendo ser evidenciadas por estarem contidas em um halo branco.

Estas células são consideradas mioblastos inativos ou células tronco latentes que podem proliferar após pequena lesão através de mitoses, dando origem a novos mioblastos (CHOU \& NONADA, 1997; JUNQUEIRA \& CARNEIRO, 1999). 
Enquanto o tecido muscular permanece livre de agressão, as células satélites permanecem em estado de quiescência (repouso). Entretanto, em resposta a estímulo como crescimento, remodelação ou trauma, as células satélites tornam-se ativas, proliferam por divisão mitótica e se fundem umas às outras para formar novas fibras musculares esqueléticas ou repararem segmentos danificados das fibras musculares existentes.

Os mioblastos fusionam-se dentro da lâmina basal, enquanto esta permanece íntegra, para formar os miotubos que, quando maduros, originam novas fibras estriadas. Em contrapartida, o rompimento da lâmina basal produz o reparo por fibroblastos do local lesado com formação de tecido cicatricial (ROSS \& ROMRELL, 1993; JUNQUEIRA \& CARNEIRO, 1999; FOSCHINI et al., 2004).

A presença de lâmina basal parece influenciar neste processo, proporcionando um substrato no qual ocorre o alinhamento, e a expressão de inúmeros componentes da matriz extracelular, no entanto, a lâmina basal é essencial para este processo, uma vez que ocorrem níveis reduzidos de regeneração, na ausência de uma lâmina intacta.

À medida que os miotúbulos maturam e diferenciam-se, estas estruturas sintetizam proteínas miofibrilares e se depositam na região sarcolêmica externa, enquanto, os núcleos musculares são "empurrados" para a periferia e alguns permaneçam na região central (KITCHEN \& YOUNG, 1998).

As células satélites estão distribuídas de forma homogênea ao longo do músculo não havendo diferenças significativas entre as regiões proximal, média e distal (MARUENDA \& ARMSTRONG, 1978).

As células satélites também entram em mitose quando o músculo é submetido a exercício intenso, onde se fundem com as fibras musculares preexistentes, contribuindo para a hipertrofia muscular (SIMÃO, 2003). 


\section{ULTRA-SOM}

\subsection{Histórico}

No início do século XX conseguiu-se produzir e detectar ondas sonoras com freqüência acima do limite audível pelo homem dando origem ao termo Ultra-som (OKUNO,1982).

A história do ultra-som remonta de 1794, quando Lazzaro Spallanzini demonstrou que os morcegos se orientavam mais pela audição do que pela visão para localizar obstáculos e presas, demonstrando que este animal tinha capacidade de emitir ondas ultra-sônicas.

Com a observação do comportamento desse tipo animal desenvolveu-se a idéia de sonares para a detecção de submarinos, utilizando o método pulso-eco.

Os efeitos biológicos do ultra-som foram notados pela primeira vez por Langevin que por volta 1917 pressentiu a aplicação prática desse tipo de energia começou a pesquisa-lá e em 1927, Robert Williams Wood, que trabalhava com Langevin, e Loomis publicaram resultados interessantes dos efeitos biológicos desse tipo energia (SHRIBER,1975). Contudo, os estudos com ultra-som em eritrócitos humanos, tecidos vegetais, microorganismos em suspensão realizados neste período, demonstraram que o ultra-som promovia lesão celular devido a uma violenta ação mecânica provocada pelo campo ultra-sônico, com a formação e vibração de bolhas (COAKLEY, 1978).

A partir de então a energia ultra-sônica foi considerada lesiva aos tecidos biológicos e este conceito perdurou por várias décadas, havendo muito pouco publicado a respeito.

Somente no final da década de 1940 e início da década de 1950 que se conseguiu com sucesso a primeira aplicação do ultra-som em medicina, sendo que a partir daí sua evolução ocorreu rapidamente, principalmente após a Segunda Guerra Mundial (OKUNO et al, 1982). 
Em 1949, durante a Primeira Conferência Internacional de Ultra-som Médico, foram apresentados alguns estudos demonstrando a efetividade do uso de baixas intensidades ultra-sônicas no tratamento de neurite, mialgia e artrite, criando uma nova expectativa em torno da energia ultra-sônica (GRAZZIANO, 1999).

Na década de 70, no Brasil, o Professor Doutor Luiz Romariz Duarte, docente do Departamento de Engenharia de Materiais da Escola de Engenharia de São Carlos USP iniciou pesquisas de aplicação com energia ultra-sônica pulsada de baixa intensidade.

O interesse do Professor Doutor Luiz Romariz Duarte neste tipo de energia originou-se do contato com os médicos ortopedistas da Santa Casa de Misericórdia de São Carlos durante seu estágio neste hospital, onde pode perceber a dificuldade dos ortopedistas em promover a consolidação de determinados tipos de fraturas. Este fato o fez investigar a possibilidade da utilização de uma técnica não invasiva para o tratamento de fraturas, levando em consideração a lei de Wolf, sobre as cargas mecânicas no metabolismo ósseo e a comprovação experimental da piezoeletricidade óssea por FUKADA e YASUDA (1957).

As pesquisas resultaram em sua tese de livre-docência intitulada "Estimulação Ultra-sônica da Regeneração Óssea" (DUARTE, 1977) e em uma tecnologia não invasiva para a consolidação de fraturas, aprovada pela FDA (EUA) em 1994 para o tratamento de fraturas recentes do terço medial da tíbia ou do terço distal do rádio/ulna e em 2000 para o tratamento de pseudoartrose.

No Brasil o Ministério da Saúde, pela "Agência Nacional de Vigilância Sanitária" (ANVISA) aprovou através da resolução $n^{\circ} 1554$ do D.O.U. de 27 de setembro de 2001 o uso dessa tecnologia para o tratamento de fraturas (GAMA, 2002; COLUCCI, 2002).

Atualmente esta técnica é uma realidade clínica em diversos países, como o Brasil. 


\subsection{Bases Físicas}

\subsubsection{Som e o Ouvido Humano}

As ondas sonoras podem ser definidas fisicamente como vibrações em um meio material sólido, líquido ou gasoso que são transmitidas através deste com uma velocidade determinada pelas propriedades mecânicas do meio (TER HAAR, 1987).

Essas ondas, ao se propagarem através de um meio elástico, podem atingir o ouvido humano e produzir uma sensação sonora.

A audição humana envolve um sistema mecânico, no qual as agitações das partículas (som) produzidas por uma fonte sonora são recebidas pelo pavilhão auricular e encaminhadas até o ouvido interno pelo canal auditivo. As ondas sonoras então movem à membrana timpânica, que separa o ouvido externo do médio, fazendo com que esta vibre.

As vibrações transmitidas vão para o interior da cóclea através de três ossículos: o martelo, a bigorna e o estribo, os quais estão ligados em cadeia, entre o tímpano e a janela oval, entrada para o ouvido interno, formando um sistema de alavancas transferindo energia das ondas sonoras vindas do ouvido externo, através do ouvido médio para o ouvido interno. No interior da cóclea encontramos os órgãos de Corti, que possui inúmeras células mecanicamente sensíveis chamadas células ciliadas. Estas células ciliadas entram em movimento à medida que a onda passa do ouvido médio para o interno, convertendo o som em sinais elétricos passando pelo nervo auditivo por potenciais de ação até o córtex auditivo que decodifica e interpreta esses estímulos nervosos.

O ouvido humano é capaz de ser excitado por ondas sonoras de freqüências entre, aproximadamente, $20 \mathrm{~Hz}$ a $20 \mathrm{kHz}$, entretanto, a sensibilidade não é uniforme em todo este intervalo de freqüência, sendo maior entre $2 \mathrm{kHz}$ e $5 \mathrm{kHz}$ (OKUNO et al, 1982).

Quando a freqüência das ondas mecânicas longitudinais ultrapassa $20 \mathrm{kHz}$ elas são chamadas de ultra-sônicas e as que apresentam freqüências inferiores a $20 \mathrm{~Hz}$ são denominadas infra-sônicas ou infra-sonora, sendo que ambas são imperceptíveis ao ouvido humano (RAMALHO JÚNIOR et al, 1940; LOW e REED, 2001). 
A razão entre a intensidade mais alta e a mais baixa do som detectável pelo ouvido humano é cerca de $10^{12}$ (OKUNO et al, 1982). A figura 07 demonstra a anatomia do ouvido humano.

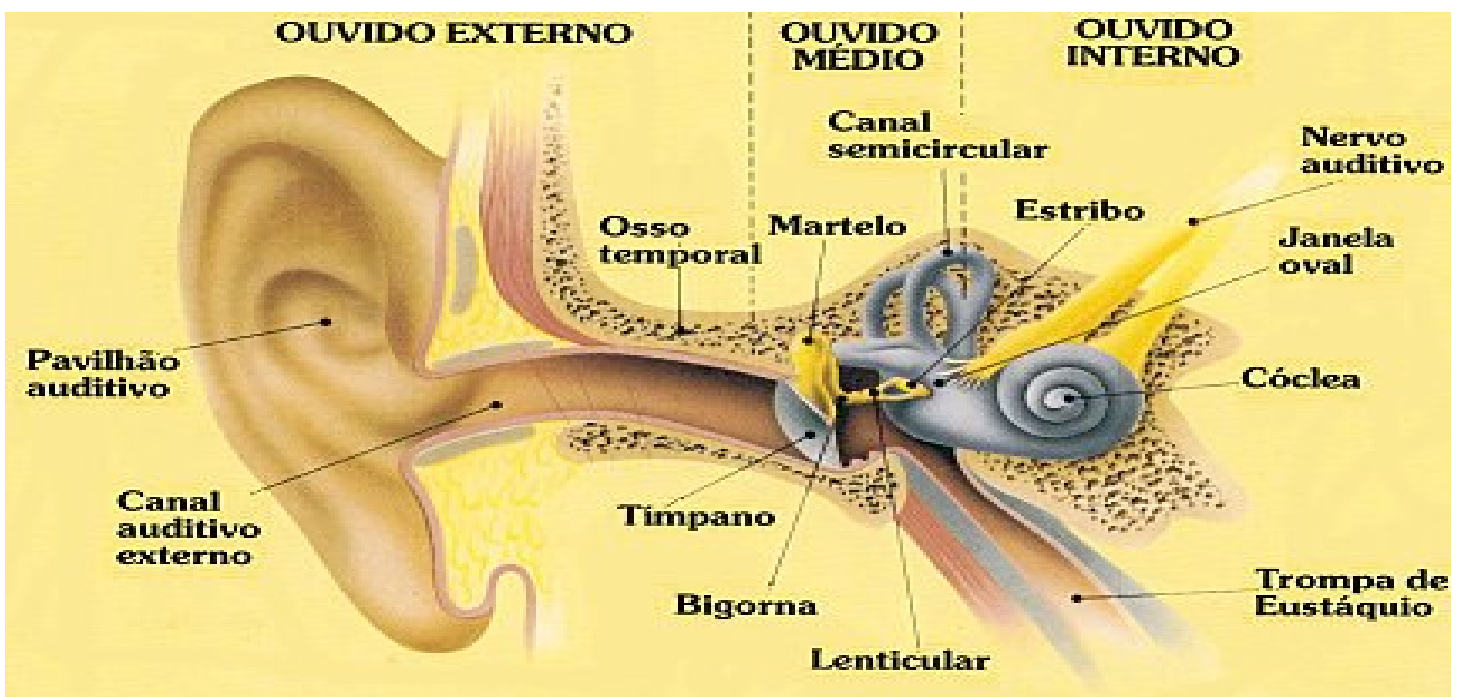

Figura 07. Esquema do ouvido humano e suas respectivas estruturas (ROCHA, 2005).

\subsubsection{Parâmetros Físicos que Caracterizam as Ondas Ultra-sônicas}

As ondas ultra-sônicas apresentam alguns parâmetros que as caracterizam como os demais tipos de onda (TER HAAR, 1978, 1987, 1998).

Comprimento de onda $(\lambda)$ :

Corresponde à distância entre pontos máximos adjacentes de compressão ou de rarefação, no qual as partículas encontram-se em um mesmo estado de movimento num dado instante de tempo. Medido em unidades de comprimento. 
Amplitude (A):

A amplitude representa o deslocamento máximo que uma partícula experimenta a partir de sua posição de equilíbrio, sendo dada em unidades de comprimento.

A figura 08 demonstra o conceito de comprimento de onda $(\lambda)$ e o conceito de amplitude (A)

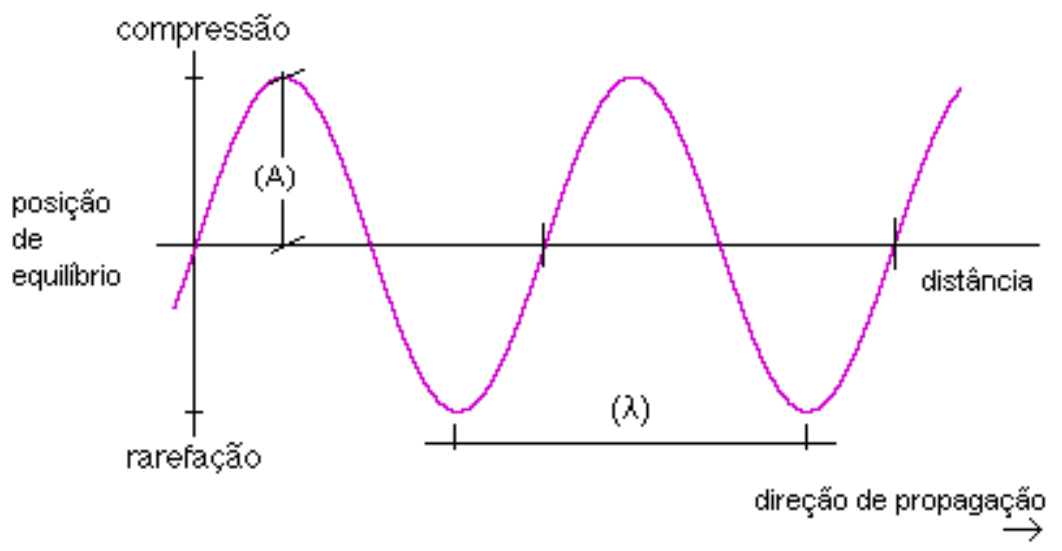
(A) - Amplitude.
$(\lambda)$ - Comprimento de Onda.

Figura 08. Deslocamento de uma partícula em função da distância.

$\underline{\text { Período }}(\tau)$ :

Corresponde ao intervalo de tempo necessário para a realização de um ciclo oscilatório completo. Medido em unidades de tempo. 
Na figura 09 podemos observar o conceito de período $(\tau)$.

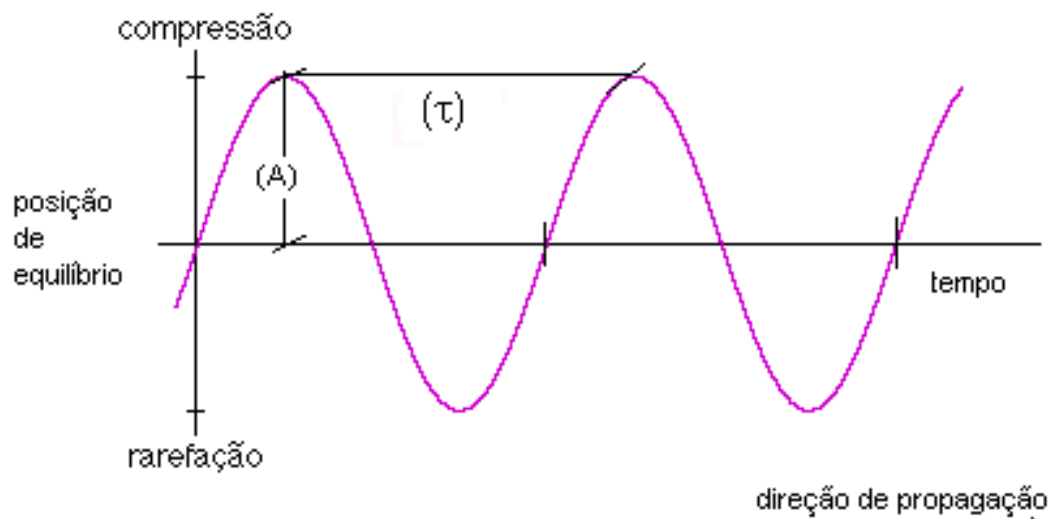

(A) - Amplitude. $\quad(\tau)$ - Período.

Figura 09. Deslocamento de uma partícula em função do tempo.

Freqüência (f):

A freqüência está relacionada com o número de ciclo oscilatório por unidade de tempo. Medida em hertz $(\mathrm{Hz})$, onde $1 \mathrm{~Hz}$ é igual a 1 ciclo por segundo.

De acordo com a freqüência o som é dividido em 3 categorias: infra-som ( $f<20 \mathrm{~Hz}$ ), som audível (f entre 20 e $20.000 \mathrm{~Hz}$ ) e ultra-som ( $\mathrm{f}>20.000 \mathrm{~Hz}$ ).

A freqüência do ultra-som determina a profundidade efetiva da penetração da energia, sendo que quanto mais elevada à freqüência, mais superficial será a sua profundidade de penetração (YOUNG, 1998).

Desta forma, a energia transmitida com uma freqüência de $3 \mathrm{MHz}$, por exemplo, será absorvida nos tecidos superficiais enquanto a energia transmitida com freqüências menores penetra mais profundamente nos tecidos (LOW e REED,1994).

O período $(\tau)$ e a freqüência (f) podem ser relacionados matematicamente pela equação 1:

$$
\tau=\frac{1}{f} \quad \text { ou } \quad f=\frac{1}{\tau}
$$


Potência $(\mathrm{P})$ :

Energia (E) total do feixe, produzida ou consumida em um dado intervalo de tempo, sendo expressa em Watts (W) (TER HAAR, 1978).

Velocidade de propagação (c):

É definida como a distância percorrida pela onda ultra-sônica por unidade de tempo, expressa em metros por segundo $(\mathrm{m} / \mathrm{s})$, podendo ser representada pela equação 2:

$$
\mathrm{c}=\frac{\lambda}{\tau} \rightarrow c=\lambda \cdot f
$$

Modos de propagação:

As ondas ultra-sônicas podem se propagar de dois modos, o contínuo e o pulsado dependendo de como a tensão do transdutor é aplicada.

No modo contínuo, não ocorre à interrupção da propagação da onda de energia, ou seja, a tensão do transdutor é aplicada continuamente durante todo o período de tratamento, havendo um depósito ininterrupto de energia sobre os tecidos irradiados.

Já no modo pulsado, há interrupções freqüentes na propagação da energia, ou seja, a tensão é aplicada durante certo tempo, pausa, volta a ser aplicada, pausa, assim sucessivamente (TER HAAR, 1998, 2001; CRISCI, 2001; GUIRRO, 2002; CRUZ, 2005).

No modo pulsado, o regime de pulso pode ser expresso de três formas diferentes (TER HAAR, 1998; LOW e REED, 1994, 2001):

1. tempo $\mathrm{x}$ de aplicação (alguns milisegundos ligado) e tempo y de pausa (alguns milisegundos desligado).

2. a razão ou relação marca: espaço (m:e), que é a razão entre comprimento do pulso para o intervalo, ou seja relação entre tempo de aplicação e tempo de pausa. Assim, se x é o dobro de y, m:e será 2:1. 
3. ciclo de trabalho ou ciclo livre, representado pela duração do pulso, como uma porcentagem do tempo total de aplicação e de pausa, ou seja, a razão entre comprimento de pulso $(\mathrm{X})$ e o comprimento total do pulso mais o intervalo $(\mathrm{X}+\mathrm{Y})$, expresso em porcentagem, sendo obtido pela equação 3:

$$
\frac{x}{x+Y} \cdot 100 \%
$$

A Figura 10 e 11 demonstra, respectivamente, os dois tipos de regimes de pulso, contínuo e pulsado.

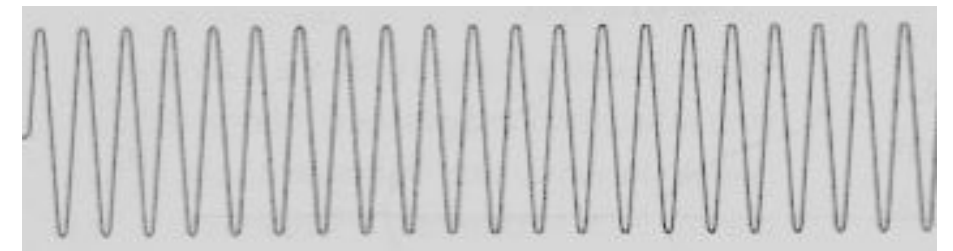

Figura 10. Regime de Propagação Contínuo.

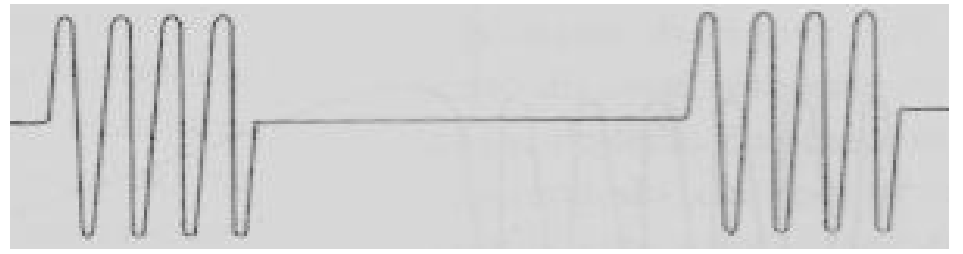

Figura 11. Regime de Propagação Pulsado.

$\underline{\text { Intensidade }}(\mathrm{I})$ :

A intensidade de uma onda é definida como a quantidade de energia (E) que atravessa uma unidade de área $(\mathrm{S})$ numa unidade de tempo (t), sendo expressa comumente por Watts $/ \mathrm{cm}^{2}$. Ao atravessar um meio, as partículas começam a vibrar e assim adquirem uma energia cinética, sendo que esta energia associada com a onda ultra-sônica é chamada de intensidade acústica (TER HAAR, 1987). 
O campo ultra-sônico pode ser dividido em duas regiões distintas, uma região próxima do transdutor conhecida como campo próximo ou zona de Fresnel e uma região além deste, conhecida como campo distante ou zona de Fraunhoffer.

Nas proximidades do transdutor ocorrem muitos picos e depressões tornando o padrão do campo disforme, no entanto, à medida que o feixe se move para mais distante do transdutor, o padrão se torna mais uniforme, como ilustrado na Figura 12.

A fronteira entre as duas zonas ou extensão da zona de Fresnel é dada pela fórmula $\mathrm{r}^{2} / \lambda$, onde $\mathrm{r}$ representa o raio do transdutor e $\lambda$ o comprimento de onda do ultrasom (TER HAAR, 1978,1998; LOW e REED, 1994, 2001), como podemos observar na figura 13.

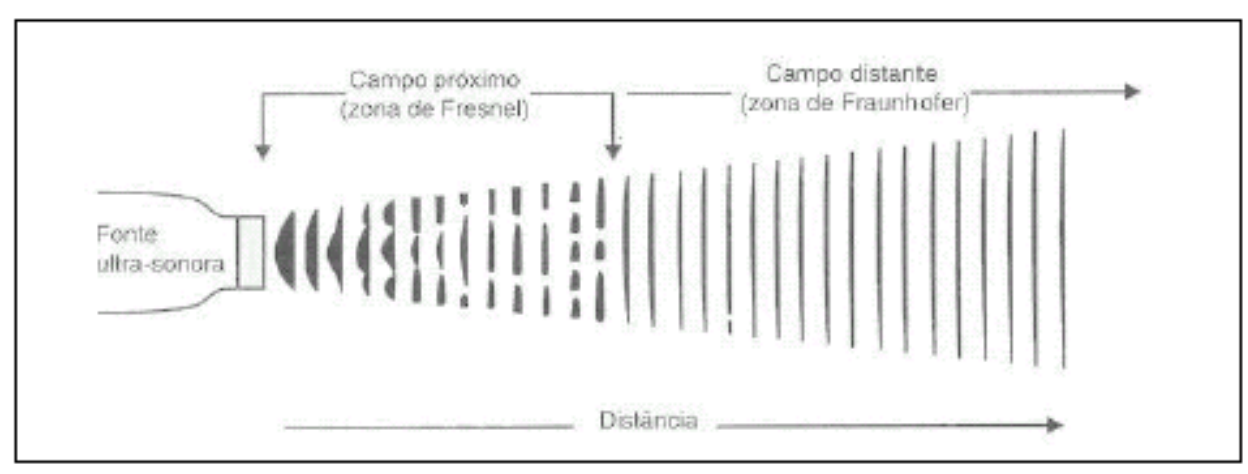

Figura 12. Comportamento do feixe ultra-sônico tornando-se mais regular com a proximidade do campo distante (LOW e REED, 2001). 


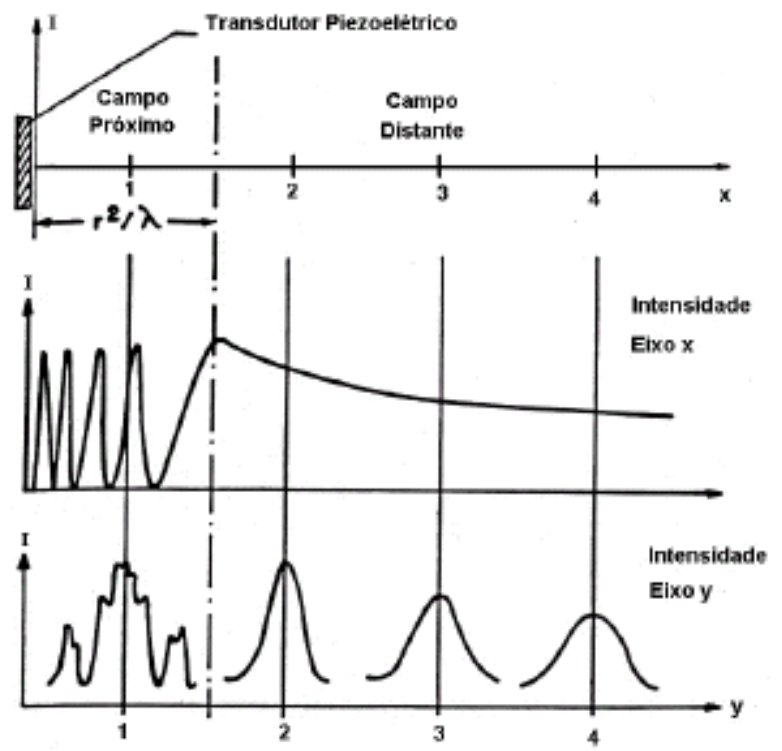

(A)

(B)

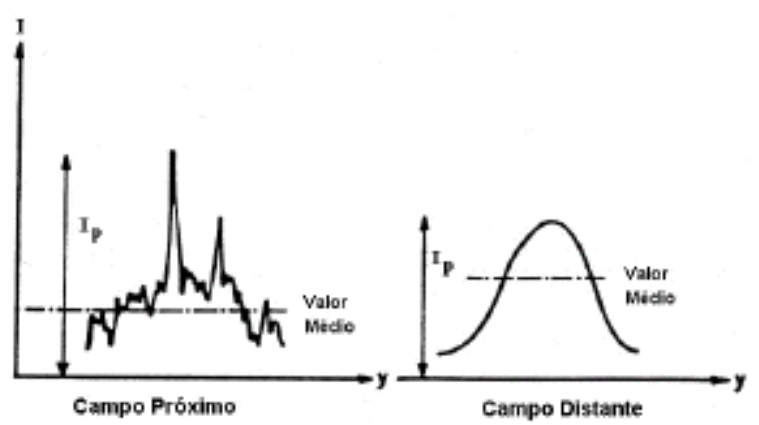

(D)

Figura 13. Variação da intensidade acústica (I) nos campos ultra-sônicos próximos e distantes, em meio aquoso. (A) Representa o transdutor piezelétrico e os campos próximo e distante. No gráfico $(\mathbf{B})$ tem-se a variação da I ao longo do eixo $\mathrm{x}$, no $(\mathbf{C})$ tem-se a variação de I ao longo do eixo y (perpendicular à página), e nos dois últimos (D), o valor da intensidade média ao longo do eixo y, numa determinada posição (ALVES, 1988 - adaptado de TER HAAR, 1978).

A intensidade esta relacionada com a amplitude de pressão pela expressão 4:

$$
\mathrm{I}=\frac{\mathrm{p}^{2}}{2 \rho c}
$$

Onde p é amplitude de pressão, c é a velocidade de propagação do som e $\rho$ é a massa específica. 
No campo de ondas contínuas são definidas duas intensidades, a intensidade de pico espacial e intensidade média espacial, já no campo das ondas pulsadas podemos identificar uma intensidade pico temporal e uma intensidade média temporal. Caso as intensidades temporais forem medidas no local onde se encontra a intensidade pico espacial, podemos então determinar uma intensidade pico temporal-pico espacial $\left(\mathrm{I}_{\mathrm{SPTP}}\right)$ e uma intensidade média temporal-pico espacial $\left(\mathrm{I}_{\text {SPTA }}\right)$ e se estas intensidades temporais forem combinadas à intensidade média espacial, pode-se então definir a intensidade média temporal-média espacial $\left(\mathrm{I}_{\mathrm{SATA}}\right)$ e a intensidade de pico temporal-média espacial $\left(\mathrm{I}_{\mathrm{SATP}}\right)$ (TER HAAR, 1998).

Atenuação:

Corresponde a uma redução exponencial da intensidade da onda ultra-sônica conforme esta se distância do transdutor (fonte), pois as ondas ultra-sônicas ao atravessarem os tecidos perdem energia, devido a dois mecanismos: 1. espalhamento ("scattering") causado por reflexões e 2. refrações na interface entre os tecidos e absorção a qual é convertida em calor levando a um aquecimento local (TER HAAR, 1978, LOW e REED, 2001).

A absorção representa $60-80 \%$ da energia perdida do feixe, sendo que esta energia dispersa pode ser absorvida por regiões além daquela que esta sendo irradiada (TER HAAR, 1998, LOW e REED, 2001).

A atenuação total do ultra-som ao se propagar em um meio pode ser representada pelo produto do coeficiente de atenuação deste meio pela espessura do mesmo, obedecendo a uma lei exponencial:

$$
\mathbf{I}=\mathbf{I}_{0} \cdot e^{-2 \mathbf{a x}}(5)
$$

Onde $\mathbf{I}$ é a intensidade do ultra-som após ter percorrido uma espessura $\mathbf{X}$ de um material com coeficiente de atenuação $\mathbf{a}$; e $\mathbf{I}_{\mathbf{0}}$ é a intensidade inicial e $\boldsymbol{e}$ o número de Neper ou Euler $(\boldsymbol{e}=2,718281828 \ldots)$. 
O coeficiente de atenuação do ultra-som geralmente aumenta com a freqüência, razão pela qual existe um limite máximo na freqüência a ser utilizada nos tratamentos com este equipamento (OKUNO et al, 1982).

A atenuação também pode ser expressa em função da potência.

A Tabela 02 mostra o coeficiente de atenuação para a freqüência de $1 \mathrm{Mhz}$ em diferentes.

Tabela 02. Coeficiente de atenuação (a) em diferentes tecidos para a freqüência de 1 Mhz (WELLS, 1977).

\begin{tabular}{cc}
\hline Tecidos & $\begin{array}{c}\text { Coeficiente de atenuação (a) } \\
\text { Unidades }\end{array}$ \\
\hline Sangue & 0.18 \\
Gordura & 0.63 \\
Cérebro & 0.85 \\
Fígado & 0.94 \\
Rim & 1.0 \\
Músculo (paralelo às fibras) & 1.3 \\
Músculo (transversal às fibras) & 3.3 \\
Miocárdio & 1.8 \\
Ossos do crânio & 20 \\
Pulmão & 41 \\
\hline
\end{tabular}


Tempo de irradiação e campo de aplicação:

O tempo de irradiação é definido como o tempo total de exposição de um meio às ondas ultra-sônicas e o campo de aplicação está relacionado com a área a ser irradiada, uma vez que, uma área maior será o tempo gasto para a realização da terapia ultra-sônica (GUIRRO, 2002).

Os tempos de aplicação considerados são de no mínimo de $1-2$ minutos e o máximo de 15 - 20 minutos; para cada área de $10 \mathrm{~cm}^{2}$ de superfície coberta (LOW e REED, 2001).

\section{Impedância Acústica $(Z)$ :}

É a propriedade que as ondas têm de se deslocarem mais facilmente em um determinado meio do que em outros, podendo ser obtida a partir do calculo da expressão: $\mathbf{Z}=$ p.c, onde, $\rho$ é a densidade e c a velocidade do som no meio. A unidade em que $\mathrm{Z}$ e expressa é medida em rayl (TER HAAR, 1998).

A impedância acústica do meio é considerada constante, pois, a velocidade do som no meio é basicamente constante dentro de uma ampla faixa de freqüência (WILLIAMS, 1983). A Tabela 03 apresenta as propriedades acústicas em diversos meios.

Tabela 03. Propriedades acústicas de vários meios (Young, 1990).

\begin{tabular}{llll}
\hline \multicolumn{1}{c}{ Meio } & \multicolumn{1}{c}{$\begin{array}{c}\text { Densidade } \\
(\mathrm{g} / \mathrm{ml})\end{array}$} & \multicolumn{1}{c}{$\begin{array}{c}\text { Velocidade do } \\
\text { som }(\mathrm{m} / \mathrm{s})\end{array}$} & $\begin{array}{c}\text { Impedância } \\
\text { Característica } \\
\left(10^{6} \mathrm{~kg}^{-2} \mathrm{~ms}^{-1}\right)\end{array}$ \\
\hline Ar & 1.293 & 331.5 & 429 \\
Água $\left(20^{\circ}\right)$ & 1.0 & 1480 & 1.52 \\
Plasma sanguíneo & 1.06 & 1570 & 1.62 \\
Gordura & 0.92 & $1460-1470$ & 1.35 \\
Fígado & 1.06 & $1540-1584$ & $1.63-1.68$ \\
Músculo & 1.07 & $1545-1630$ & $1.65-1.74$ \\
Osso & $1.38-1.81$ & $2710-4080$ & $3.75-7.38$ \\
\hline
\end{tabular}


Reflexão e Refração:

A onda sonora ao se deparar com a interface de dois meios diferentes, ocorrerá que, parte da energia será refletida e parte da energia será refratada. A onda refletida na interface retorna ao meio incidente com a mesma velocidade de propagação que se aproximou, entretanto, a onda refratada continua em direção positiva, mas a sua velocidade se altera em função das características do meio (WELLS, 1977; WILLIAMS, 1983; HOOGLAND, 1986, GUIRRO e GUIRRO, 2002).

A Figura 14 ilustra os fenômenos citados anteriormente.

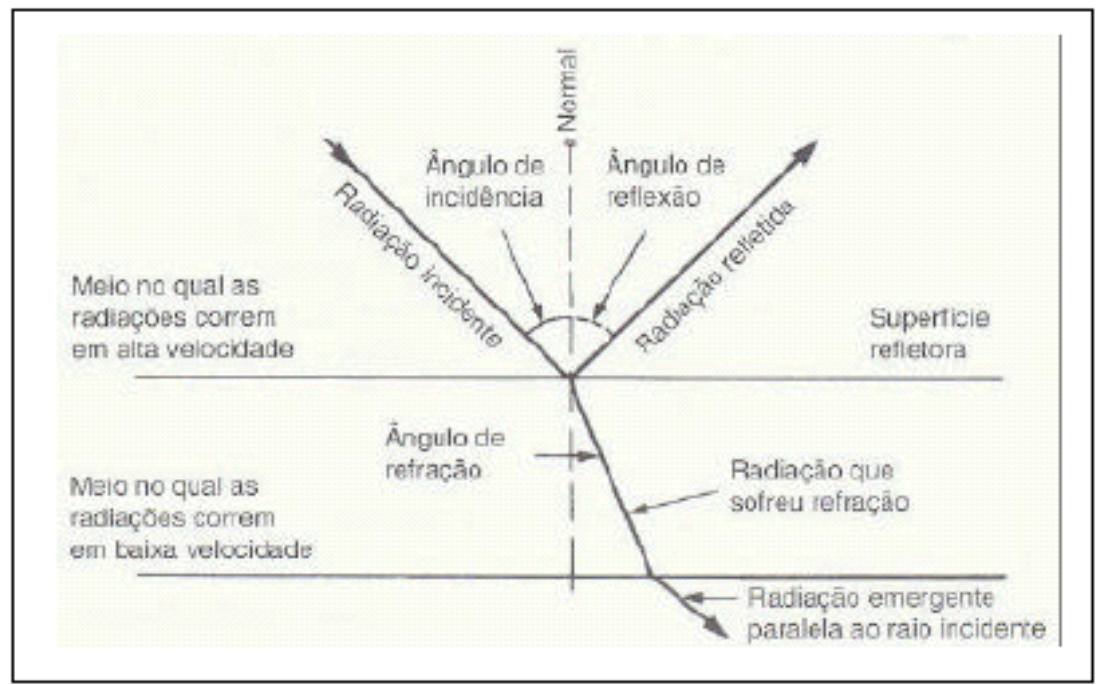

Figura 14. Reflexão e Refração do Ultra-som (LOW e REED, 2001).

A porcentagem de energia refletida e refratada depende do ângulo de incidência e da diferença da impedância acústica entre os meios na qual o ultra-som esta sendo aplicado (LOW e REED, 2001).

Obtemos a porcentagem de energia refletida $\left(\alpha_{\mathrm{r}}=\mathrm{I}_{\mathrm{r}} / \mathrm{I}_{\mathrm{i}}\right)$ e a transmitida ou refratada $\left(\alpha_{t}=I_{t} / I_{i}\right)$ através das equações 07 e 08 , sendo respectivamente, $I_{i}, I_{r}, I_{t}$ as intensidades incidente, refletida e transmitida. Os ângulos de incidência e transmissão são $\theta_{\mathrm{i}}$ e $\theta_{\mathrm{t}}$, respectivamente (WELLS, 1977). 


$$
\begin{gathered}
\alpha_{r}=\frac{I_{r}}{I_{i}}=\left(\frac{Z_{2} \cos \theta_{i}-Z_{1} \cos \theta_{t}}{Z_{2} \cos \theta_{i}+Z_{1} \cos \theta_{t}}\right)^{2} \\
\alpha_{t}=\frac{I_{t}}{I_{i}}=\frac{4 Z_{2} Z_{1} \cos \theta_{i} \cos \theta_{t}}{\left(Z_{2} \cos \theta_{i}+Z_{1} \cos \theta_{t}\right)^{2}}
\end{gathered}
$$

Se a incidência da frente de onda for perpendicular ao segundo meio, isto é, $\theta_{\mathrm{i}}=$ $90^{\circ}$, as equações citadas acima podem ser simplificadas, como mostra as equações 9 e 10:

$$
\begin{aligned}
& \frac{I_{r}}{I_{i}}=\left(\frac{Z_{2}-Z_{1}}{Z_{2}+Z_{1}}\right)^{2} \\
& \frac{I_{r}}{I_{i}}=\frac{4 Z_{2}-Z_{1}}{\left(Z_{2}+Z_{1}\right)^{2}}
\end{aligned}
$$

\section{Transdutores:}

Pierre e Jacques Curie, em 1880 descobriram o fenômeno chamado efeito piezoelétrico, que consiste na variação das dimensões físicas de certos materiais sujeitos à campos elétricos, onde as cargas da rede cristalina interagem com o material produzindo uma tensão mecânica (OKUNO et al, 1982; GUIRRO e GUIRRO, 2002). Um campo elétrico aplicado no cristal produz uma variação alternada de sua espessura, que se manifesta como uma vibração e resulta em ondas mecânicas (TER HAAR, 1998).

Os transdutores são dispositivos utilizados nos equipamentos de ultra-som que utiliza o efeito piezoelétrico para transformar a energia elétrica em energia mecânica (TER HAAR, 1998). 
Sabe-se, hoje que, a piezoeletricidade é uma propriedade natural de certos cristais e substâncias cristalinas que apresentam anisotropia, ou seja, a capacidade de reagir diferentemente de acordo com a direção de propagação de um fenômeno físico, como a propagação da luz ou do calor, dureza, etc (RICHARDSON, 1989).

Alguns cristais como o quartzo e a turmalina podem ser utilizados como transdutores, pois apresentam piezoeletricidade naturalmente. Entretanto, alguns transdutores podem ser produzidos artificialmente em materiais cerâmicos sintéticos, após serem submetidos a um processo de polarização elétrica, como o sulfato de lítio, o fosfato diidrogenado de amônia, o titânio de Bário $\left(\mathrm{BaTiO}_{3}\right)$ e o titanato zirconato de chumbo (PZT), o qual é o material piezoelétrico mais comumente utilizado nos transdutores terapêuticos (OKUNO et al, 1982; RICHARDSON, 1989; LOW e REED,1994; GUIRRO e GUIRRO, 2002).

No presente trabalho foi utilizado como transdutor para a produção de ondas ultra-sônicas, o titanato zirconato de chumbo (PZT) na forma de um disco circular e freqüência de ressonância de $1.5 \mathrm{MHz}$.

\subsection{Interação do Ultra-som com os Tecidos}

O ultra-som ao penetrar no corpo pode exercer sobre as células e os tecidos moles efeitos mediante dois mecanismos: térmicos ou atérmicos (bioefeitos).

O resultado da absorção do ultra-som nos tecidos é a oscilação de partículas em torno de sua posição média. Essa oscilação, ou energia sonora, é convertida em energia térmica proporcional a intensidade do ultra-som. O ultra-som de baixa intensidade, a dissipação do calor equivale a geração de calor, não havendo uma resultante elevação da temperatura, efeitos atérmico, diferentemente do ultra-som de maior intensidade, no qual o calor não é dissipado levando a um aumento da temperatura local, resultando no efeitos térmicos. 
O ultra-som térmico promove um aumento de temperatura tecidual. $\mathrm{O}$ aquecimento promovido nas estruturas constituídas por tecido fibroso, como as cápsulas articulares, ligamentos e tendões, pode gerar um aumento temporário na extensibilidade, levando a uma redução da rigidez articular. O aquecimento tecidual leve gerado pelo ultra-som ocasiona um incremento do fluxo sangüíneo local, amplificando a permeabilidade da membrana e a distensão das fibras colágenas, conduzindo a um aumento os processos de cicatrização dos tecidos lesados e da sua elasticidade, podendo também levar ao alívio da dor, diminuição do espasmo muscular (LOW e REED,1994; GUIRRO e GUIRRO, 2002).

O ultra-som atérmico, não promove aquecimento tecidual utilizando-se apenas dos efeitos biofísicos gerados pelo ultra-som, como a cavitação, microfluxo acústico e as correntes acústicas e a piezoeletricidade, que serão discutidos a seguir.

A interação entre o ultra-som pulsado de baixa intensidade (USP) produzido no Departamento de Bioengenharia da Universidade de São Paulo, campos São Carlos, e os tecidos biológicos depende somente dos efeitos biofísicos gerados pelo ultra-som, e não de seus efeitos térmicos.

\section{Cavitação:}

O termo cavitação parece ter sido usado primeiro por Sir John Thornycroft, no princípio de século 20, para definir a formação de bolhas em líquidos (BAKER et al, 2001).

Em geral, o termo cavitação é usado para descrever a formação de pequenas bolhas gasosas em meio líquido, no caso, sangue ou em fluidos teciduais resultantes da vibração do ultra-som, devido às mudanças de pressão induzidas pelo estímulo acústico. (LOW e REED, 1994; YOUNG, 1998, GUIRRO e GUIRRO, 2002).

Essas bolhas formadas pela passagem de ondas ultra-sônicas no tecido biológico podem permanecer intacta por muitos ciclos (cavitação estável) ou entrar em colapso liberando grande quantidade de energia (cavitação transiente) (WELLS, 1977; GUIRRO e GUIRRO, 2002). 
A cavitação estável é a forma menos violenta de cavitação, estando associada com a vibração dos corpos gasosos que geralmente oscilam de forma não linear, em equilíbrio, podendo permanecer neste estado por muitos ciclos de pressão acústica (MAXWELL, 1995). Essas bolhas podem aumentar ou diminuir de tamanho, sendo que quando tais oscilações volumétricas se estabilizam, as bolhas de gás podem promover um fluxo ou oscilações no meio, conhecidas como microondulações acústica.

A cavitação transiente (instável ou transitória), dura menos de um ciclo, ocorre quando há uma violenta implosão das cavidades ou microbolhas produzindo intensas ondas de choques ou campos de cisalhamento hidrodinâmico, aumentos instantâneos da temperatura e pressão e efeitos químicos (LOW e REED, 1994; GUIRRO e GUIRRO, 2002).

A cavitação estável, associada às correntes acústicas é considerada de valor terapêutico, visto que seus efeitos são basicamente não térmicos, no entanto, a cavitação transiente, que provavelmente só ocorre com altas intensidades, pode causar danos teciduais (LOW e REED, 1994).

\section{$\underline{\text { Microfluxo acústico e Correntes acústicas: }}$}

O fluxo ou corrente acústica consiste em movimentos unidirecional e circulatório constante devido ao torque de radiação (LOW e REED, 2001). Quando ocorrem movimentos pequenos ao longo da fronteira das membranas celulares, fibras de tecido ou de outras interfaces e esses movimentos são resultantes da pressão mecânica exercida pela radiação ultra-sônica, este efeito, então passa a se chamado microfluxo acústico ou microcorrenteza (LOW e REED, 2001; CRUZ, 2005).

Esses efeitos podem dar origem a forças e tensões hidrodinâmicas que dependendo de sua magnitude podem causar danos irreversíveis às células e as macromoléculas suspensas ou reversíveis e de valor terapêutico, visto que o microfluxo exerce sobrecarga viscosa sobre a membrana da célula, podendo aumentar a sua permeabilidade que pode alterar a taxa de difusão aos íons, levando a inúmeras alterações como aumento na captação de cálcio, maior produção de fator de crescimento pelos macrófagos, aumento na secreção dos mastócitos, aumento na síntese de proteína, estimulando o processo de reparo, entre outras (OKUNO et al, 1982; LOW e REED, 1994, 2001). 


\section{Piezoeletricidade:}

A piezeletricidade foi descoberta em 1880 por Pierre e Jacques Curie, quando estes estudavam o efeito da pressão na geração de cargas elétricas por cristais como a turmalina, o quartzo e o sal de Rochelle (GUIRRO e GUIRRO, 2002; CARBONARI, 2003).

A piezeletricidade pode ser definida como a polarização elétrica produzida por uma deformação mecânica ou tensão elétrica em certos tipos de cristais que quando submetidos a um campo elétrico, sofre alterações em suas dimensões, sendo também o inverso válido, ou seja, quando o material piezelétrico sofre uma deformação, um campo elétrico é gerado.

Os efeitos piezelétricos são características de todos os cristais ferroelétricos (CARBONARI, 2003).

Os primeiros a descreverem a piezoeletricidade em tecidos biológicos foram FUKADA \& YASUDA (1957) onde observaram os efeitos direto e inverso da piezeletricidade no osso, demonstrando que este ao sofrer uma deformação mecânica, formava-se cargas elétricas na face oposta do osso, devido à presença de moléculas de colágeno existentes.

SILVA (1987) em seu estudo demonstrou que a aplicação de um campo acústico no tecido ósseo produz um campo elétrico ao redor da membrana celular e o que levou a pensar que este efeito deve ocorrer em todos os tecidos que apresentam colágeno.

\subsection{Dosimetria}

GUIRRO et al (1997) relataram em seus estudos que a maior parte dos equipamentos testados apresentavam-se fora das especificações da Comissão Eletrônica Internacional, independente do tempo de uso do aparelho ultra-sônico.

Mediante a este fato, a energia transmitida pelos transdutores ultra-sônicos devem ser periodicamente dosadas.

Os diferentes métodos de medidas de energia do campo acústico ultra-sônico podem ser divididos em três grupos principais (GUIRRO e GUIRRO, 2002):

O primeiro grupo compreende o método universal térmico (calorímetros), no qual a energia das ondas atenuadas é convertida em calor e então aferida. 
O segundo grupo consiste em métodos que aferem a pressão acústica, a sua velocidade ou deslocamento, utilizando geralmente sensores piezoelétricos, capacitivos, eletrodinâmicos e alguns meios ópticos.

O terceiro grupo baseia-se na aferição da força de radiação, através de uma Balança de Força de Radiação, assim denominada devido ao fato dessa força ser medida com auxílio de uma balança mecânica ou eletrônica.

O princípio básico desse processo consiste em um campo acústico ultra-sônico que ao atingir um objeto exerce uma força denominada "força de radiação" $\left(\mathrm{F}_{\mathrm{rad}}\right)$, proporcional à potência incidente. A expressão da força pode ser representada pela equação (11) abaixo, caso o objeto absorva completamente a energia incidente.

$$
\mathrm{F}_{\mathrm{rad}}=\frac{W}{C}
$$

Onde c é a velocidade do ultra-som no meio onde o objeto esta imerso geralmente água (ZISKIN, 1993).

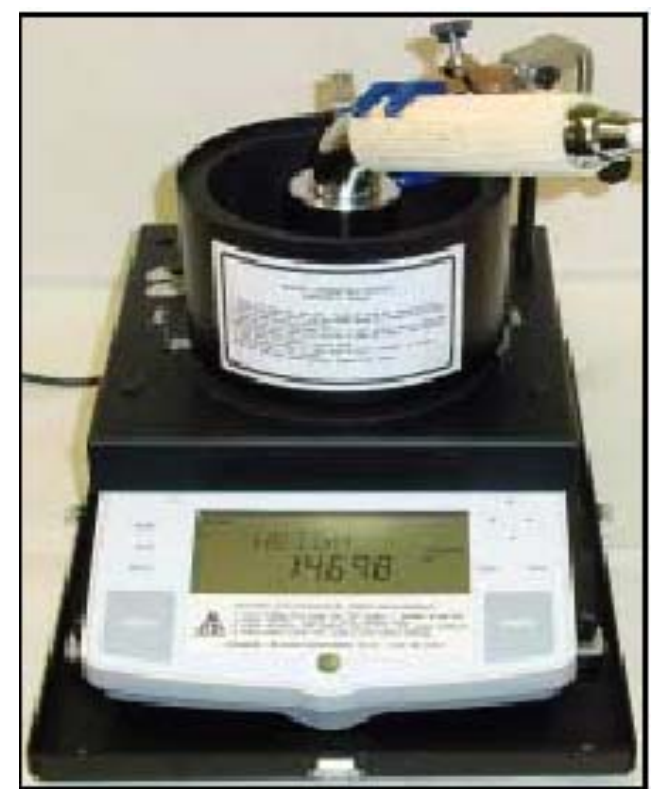

Figura 15. Representação de uma balança de força de radiação (dosímetro modelo UPM-DT-1 Ohmic Intruments Co, EUA). 


\subsection{Princípios do reparo dos tecidos muscular após uma lesão e a atuação do ultra- som em cada fase.}

A reação de cicatrização dos tecidos (reparo) é um processo complexo que envolve ações integradas das células, matriz e mensageiros químicos visando restaurar a integridade do tecido lesionado.

O processo de reparo é comumente caracterizado em 3 fases que se sobrepõem e ocupam extensões variáveis de tempo, sendo: a fase inflamatória ou inicial (até o $4^{\mathrm{o}}$ dia), a fase fibroblástica ou de proliferação (até o $14^{\circ}$ dia) e a fase de remodelamento ou maturação (a partir do 14 dia) (KITCHEN e YOUNG, 1998; LOW e REED, 2001; GUIRRO e GUIRRO, 2002; AMÂNCIO, 2003).

\subsubsection{Fase Inflamatória ou Inicial:}

A fase inflamatória é a resposta imediata e dinâmica à lesão, sendo iniciada no momento em que a integridade do tecido é rompida. A lesão ao tecido provoca morte celular em conseqüência da agressão direta, de deficiência de oxigênio devido à ruptura de vasos sanguíneos ou pela liberação de agentes químicos das células vizinhas lesionadas.

Essa fase é caracterizada pela presença de quatro sinais: calor, dor, rubor e tumor (KITCHEN e YOUNG, 1998), no entanto, alguns autores como LOW e REED (2001) trazem um quinto sinal: a perda da função.

A perda de sangue dos tecidos inicia diretamente a atividades das plaquetas e a coagulação sanguínea, resultando na geração de fatores químicos, como a bradicinina, além disso, o coágulo sanguíneo proporciona uma matriz provisória que facilita a migração das células até a ferida. Estes fatores químicos afetam a circulação local, estimulam a produção de outros mediadores químicos e funcionam como agentes de atração de células, como neutrófilos, monócitos, macrófagos, entre outras (KITCHEN e YOUNG, 1998).

WILLIANS (1974, 1976) demonstrou que as forças geradas pela corrente acústica produzem alterações na permeabilidade da membrana da plaqueta, levando à liberação de serotonina e outros fatores essências para o processo de reparo. 
Os efeitos da cavitação estável e da corrente acústica parecem aumentar a difusão do cálcio através da membrana celular, sendo este fato de grande significado clínico, visto que o cálcio, em seu papel de mensageiro intracelular, ou segundo mensageiro, pode ter um efeito acentuado no aumento da produção e liberação de fatores que contribuem para a cicatrização, como a liberação de histamina pelos mastócitos (LOW e REED, 2001).

O processo de desgranulação mastocitária pode ser estimulado por um único tratamento de ultra-som, administrado após a lesão, ocorre o rompimento da membrana celular, em resposta a um aumento nos níveis de cálcio intracelular, com a liberação de histamina e outros produtos no local da ferida, facilitando a regeneração (YOUNG, 1998).

Estudos demonstram que a uma freqüência menor, por exemplo, $0,75 \mathrm{MHz}$ é mais efetiva na liberação imediata dos fatores já presentes no citoplasma, como o crescimento da população de fibroblastos, que uma freqüência mais elevada (3 MHz), podendo isto ser mais provável devido a ocorrência de cavitação na freqüência mais baixa e a ocorrência de aquecimento na freqüência mais elevada (YOUNG, 1998).

O ultra-som tem o potencial de acelerar a resolução normal de uma inflamação, desde que o estímulo inflamatório seja removido, sendo que esta aceleração deve-se entre outros fatores a agitação do líquido dos tecidos que pode aumentar a taxa de fagocitose e o movimento das partículas e células (LOW e REED, 2001).

Contudo, o ultra-som possui somente uma ação pró-inflamatória e não antiinflamatória, uma vez que este incentiva a formação mais rápida do edema, e em seguida o edema desaparece mais rapidamente, o que acelera todo o evento e orienta mais precocemente a ferida para a fase proliferativa do reparo (YOUNG, 1998).

\subsubsection{Fase fibroblástica ou de proliferação:}

Durante esta fase do processo de cicatrização, ocorre a formação de um tecido de granulação, que nada mais é que uma estrutura temporária, constituída por neomatriz, neovascularização, macrófagos e fibroblastos, englobando os processos de proliferação e migração dos fibroblastos e o desenvolvimento das matrizes colágenas e não-colagenosas (“Fibroplasia”) (KITCHEN \& YOUNG, 1998). 
Segundo YOUNG (1998) quando os tecidos são expostos ao ultra-som in vivo, pode-se observar um aumento significativo na quantidade de células no leito da ferida, sendo altamente provável que a proliferação de fibroblastos seja devida a ação indireta do ultra-som, através dos macrófagos, uma vez que há pouca evidência na literatura sugerindo que o ultra-som exerça um efeito estimulante sobre os fibroblastos.

HOGAN et al. (1982) demonstraram que o ultra-som também é capaz de incrementar a velocidade da angiogênese, uma vez que os capilares se desenvolviam mais rapidamente no músculo cronicamente isquêmico, quando este era exposto ao ultra-som.

Quando os fibroblastos são expostos ao ultra-som in vitro, pode ser detectada uma significativa secreção de colágeno, dependendo da intensidade, levando a uma maior força tênsil do tecido (YOUNG, 1998).

Outro fator que o ultra-som atua é na aceleração da contração da ferida, por este fato este ser muito usado no tratamento de úlceras varicosa, úlceras de decúbito, pé diabético e na hanseníese (YOUNG, 1998; CAMPANELLI, 2005).

\subsubsection{Fase de remodelamento ou maturação:}

Esta fase pode se prolongar desde meses até anos, dependendo do tecido, a natureza da lesão e de quando foi realizado o tratamento com o ultra-som e quando este se iniciou.

Considera-se que o ultra-som melhore a extensibilidade do colágeno maduro e aumento da resistência tênsil do tecido cicatricial.

$\mathrm{O}$ inicio do tratamento na fase inflamatória não apenas aumenta a quantidade de colágeno depositado na ferida, mas também incentiva a deposição do colágeno num padrão cuja arquitetura se assemelha com a pele não lesionada (YOUNG, 1998; LOW e REED, 2001). 


\section{REVISÃO DA LITERATURA}

CARLSON \& FAULKNER (1983), relatam que as lesões musculares apesar de terem grande incidência, não receberam a atenção devida dos especialistas, ao contrário, das lesões ósseas articulares e ligamentares. Contudo, nos últimos anos com o crescimento das atividades físicas e desportivas e a necessidade de recuperação rápida e eficaz dos atletas, as lesões musculares tornaram-se objeto de estudo.

PREDDY et al. (2001b, 2002) relatam que a doença muscular induzida pelo álcool (AIMD) é um termo composto para descrever qualquer patologia (molecular, bioquímica, estrutural, ou fisiológica) que afete o músculo como conseqüência da ingestão aguda ou crônica de álcool.

PREEDY et al. (2003) admitem que a lesão causada pela miopatia alcoólica esta delimitada a fibra muscular tipo II, particularmente a tipo IIb, enquanto que a fibra tipo I esta relativamente protegida. O diagnóstico da miopatia esta baseado na atrofia muscular, diminuição do diâmetro da fibra.

FERNANDEZ-SOLÁ et al. (1995) realizaram através de biópsia do músculo deltóide, o diagnóstico histológico da miopatia alcoólica de acordo com o critério de Mastaglia e Watson (1982) classificando-a em suave, moderada e severa e também a análise histomorfométrica, com a utilização de processador de imagem, verificando o diâmetro e a área de cada tipo de fibra muscular.

WORRALL et al. (2001) em sua pesquisa realizaram a avaliação do músculo sóleo e do músculo plantar de ratos Wistar que foram submetidos a uma dieta nutricional completa e uma dieta líquida contendo 35\% do total da energia de etanol e outro grupo controle que obteve a mesma dieta sólida, sendo o etanol foi substituído por uma bebida isocalórica de glicose. Neste estudo, sugeriram que acetaldeído é a causa da miopatia alcoólica.

OHLENDIECK et al. (2003) admitem que os alcoolistas que sofrem de miopatia alcoólica podem perder $20 \%$ da sua musculatura esquelética e que a inatividade física pode contribuir para a miopatia e a fraqueza muscular, piorando a qualidade de vida. 
DUANE e PETERS (1988) concluíram que a miopatia alcoólica ocorre independente da debilidade nutricional, mesmo a má nutrição sendo freqüente nos dependentes do álcool.

Segundo OHLENDIECK et al. (2003), o álcool provoca efeitos sobre a membrana muscular alterando a permeabilidade aos íons cálcio e HALLER et al. (1984) a alteração bioquímica da membrana modifica a permeabilidade ao potássio.

Para ALLBROOCK (1962) a habilidade das fibras musculares estriadas sofrerem regeneração é um fato bem estabelecido, contudo a maneira como ocorre a regeneração é um campo aberto a investigações.

BODINE-FOWLER (1994), admitiu que o músculo esquelético tem uma grande capacidade de regeneração de suas fibras após uma lesão direta, como por exemplo, esmagamento, isquemia, congelamento, aplicação local de anestésico, exercícios exaustivos, doenças neuromusculares, seja esta lesão completa ou parcial.

CARLSON \& FAULKNER (1983), acreditam que a regeneração é a única adaptação que ocorre no músculo esquelético após uma lesão e que a regeneração resulta na restauração, em certa medida, da estrutura e função original do músculo. Estes autores comparam estruturalmente e funcionalmente a regeneração muscular com o desenvolvimento embrionário.

CRISCO et al. (1994) utilizaram em seu estudo um modelo de lesão por impacto reproduzindo uma contusão muscular difusa no músculo gastrocnêmio. Avaliaram o trauma, no mesmo dia da lesão (dia 0) e nos dias 2, 7 e 24 após o mesmo. Observaram, que no dia 0 , houve intensos edema e hematoma; no $2^{\circ}$ dia pós trauma, intenso processo inflamatório, evidenciado pela presença de macrófagos e células polimorfonucleadas; no $7^{\circ}$ dia, intensa proliferação celular de mioblastos e fibroblastos; e no $24^{\circ}$ dia o músculo estava regenerado.

FISHER et al. (1990) também utilizaram em seu trabalho um modelo de lesão traumática por impacto no músculo gastrocnêmio, sacrificando os animais após 1, 2, 3, 6, 14, 21 e, 30 dias após a lesão, sendo então analisados por microscopia eletrônica. Consideraram que após 24 horas do trauma, o músculo apresentava uma grosseira dilaceração e degeneração. Após as 24 até 48 horas observaram um aumento significativo do número de núcleos sarcolemais e que depois de 3 dias células regeneradoras do músculo desenvolveram núcleos centrais e reorganizaram os sarcômeros. 
MINAMOTO et al. (1999) avaliaram o músculo sóleo após contusão simples e recorrente produzida por impacto. Através de técnicas histoquímicas e histológicas, observaram a regeneração muscular espontânea no $1^{\circ}, 4^{\circ}$ e $6^{\circ}$ após o trauma simples e $6^{\circ}$ e $30^{\circ}$ após o trauma recorrente (uma vez por semana por 10 semanas). Na contusão simples verificaram que não houve diferença significativa no peso entre o membro lesado e o outro membro, embora o membro lesado apresenta-se alguns sinais de dano agudo. Já na contusão recorrente houve um aumento do peso no músculo lesado e grande incidência de sinais de danos crônicos, contudo não houve alteração na incidência dos tipos de fibras (I, II e IIc) entre o músculo lesado e o não lesado periodicamente.

CAMPION (1984) em seu artigo de revisão sobre as células satélites relata que estas são conhecidas desde 1961 e que participariam da regeneração muscular funcionando como célula tronco da miogênese para produzir mioblastos que se alinham, usando como suporte as lâminas basais remanescentes, ou migram para o interstício para produzir uma nova fibra.

BISCHOFF (1975) teve como finalidade em seu trabalho estudar a origem e o comportamento dos mioblastos mononucleares durante a regeneração muscular através de um sistema de cultura de células esqueléticas isoladas de ratos adultos “in vitro". Observou nos primeiros eventos da regeneração muscular, a ativação e proliferação de células satélites e sua fusão com suas progenitoras.

BRASSEUR et al. (1997), procuraram verificar o grau de regeneração nos diferentes estágios da distrofia de Duchenne, analisando a expressão de vários marcadores de proliferação celular e diferenciação muscular. Através do estudo da expressão de marcadores musculares como a isoforma da miosina de cadeia pesada, foi possível determinar mais precisamente o grau de maturação e diferenciação das fibras musculares regeneradas.

VILA et al. (2001), demonstraram em seu estudo a relação entre a miopatia alcoólica e atividade física. Utilizaram um modelo pré estabelecido de treinamento físico e de ingestão alcoólica. Observaram o comportamento dos músculos sóleo (predominância de fibra tipo I), plantares (predominância de fibra tipo IIa, IIb), gastrocnêmio (predominância de fibra tipo I e II), da atividade enzimática, da capilaridade e das áreas das fibras musculares, nos diversos grupos pesquisados. 
RANTANEN et al. (1999), trataram experimentalmente a lesão do músculo gastrocnêmio do rato com ultra-som terapêutico pulsado em lesão produzida por contusão. A velocidade da mioregeneração dos animais tratados com ultra-som (US) foi comparada aos controles por imunohistoquímica, morfometria e análise cintilográfica. Embora as células satélites tivessem aumentado 96\% nos tratados com ultra-som, durante os primeiros estágios da regeneração, não houve o mesmo efeito na produção de miotubos. Embora o ultra-som promova um aumento na proliferação de células satélites na fase regeneração muscular, não parece ter efeitos significativos sobre as demais manifestações morfológicas da regeneração muscular.

MARKERT et al. (2005), objetivaram determinar se o ultra-som terapêutico não térmico e exercícios de baixa intensidade influenciavam na regeneração do músculo esquelético, após uma contusão experimental. Compararam a lesão no músculo gastrocnêmio de grupos que receberam somente tratamento com exercício, grupo exercício mais ultra-som, grupo somente tratado com ultra-som e um ultimo grupo sem ultra-som e sem exercício. Concluíram que não há evidencias que especificamente o protocolo de ultra-som e exercício investigados aumentasse a regeneração muscular após a contusão. 


\section{MATERIAL E MÉTODOS}

\subsection{Animais de Experimentação:}

Para este trabalho experimental foram selecionados 20 ratos machos, da linhagem Wistar, com mais ou menos um mês de idade e peso corporal variando entre $100 \pm 20 \mathrm{~g}$, provenientes do Biotério Central da Universidade Federal de São Carlos (UFSCar).

Os animais foram mantidos no Biotério do Laboratório de Fisiologia de Exercício da UFSCar, acondicionados em gaiolas apropriadas de polietileno padrão, em grupos de 5 animais por gaiola, sob condições ambientais controladas, com ritmo circadiano de luz e escuro, em ambiente higienizado com temperatura e ventilação adequados, recebendo água ou aguardente de cana diluída e, ração balanceada ad libitum, durante todo o período experimental.

No início do experimento os animais foram pesados e identificados com ácido pícrico, de acordo com a experimentação convencionada. Os animais foram repesados antes do sacrifício.

\subsection{Agrupamento:}

Convencionamos distribuir os 20 animais aleatoriamente em 4 grupos, sendo:

\section{Grupo Experimental I $(\mathrm{n}=5)$ :}

Os animais deste grupo receberam durante o experimento aguardente de cana diluída como único alimento líquido, com aumento progressivo da diluição, começando com $5 \%$, chegando ao término do experimento a $30 \%$ e, não realizaram o programa de treinamento de exercício físico em esteira elétrica. 
Grupo Experimental II $(\mathrm{n}=5)$ :

Os animais deste grupo, considerados como controle do grupo I, receberam durante o experimento água como único alimento líquido e não realizaram o programa de treinamento de exercício físico em esteira elétrica.

\section{Grupo Experimental III ( $\mathrm{n}=5)$ :}

Os animais deste grupo receberam durante o experimento aguardente de cana diluída como único alimento líquido, com aumento progressivo da diluição, começando com 5\%, chegando ao término do experimento a 30\% e, realizaram o programa de treinamento de exercício físico em esteira elétrica.

\section{Grupo Experimental IV ( $\mathrm{n}=5)$ :}

Os animais deste grupo, considerados como controle do grupo III, receberam durante o experimento água como único alimento líquido e realizaram o programa de treinamento de exercício físico em esteira elétrica.

\subsection{Programa de Treinamento:}

Inicialmente foi realizado um pré-treinamento diário com os animais correndo na esteira elétrica (figura 16) por 5 minutos com uma velocidade de $5 \mathrm{~m} / \mathrm{min}$, com aumento gradual até chegar nos parâmetros de treinamento estipulado, para que os animais se familiarizassem com a manipulação e com o protocolo experimental.

O treinamento dos animais foi realizado com corrida em uma esteira elétrica (figura 16), 4 dias por semana por 12 semanas (3 meses), com um período de adaptação de 2 semanas. As sessões de treinamento se iniciaram com 30 minutos de corrida, em uma velocidade de $20 \mathrm{~m}$ por minuto, com uma inclinação de $0 \%$. Os parâmetros citados acima foram aumentados em 5 minutos a cada 2 semanas até os animais estarem correndo 1 hora. A velocidade foi aumentada em $1 \mathrm{~m} / \mathrm{min}$ também a cada 2 semanas e a inclinação se manteve em 0\% durante todo o período experimental (VILA et al., 2001). 


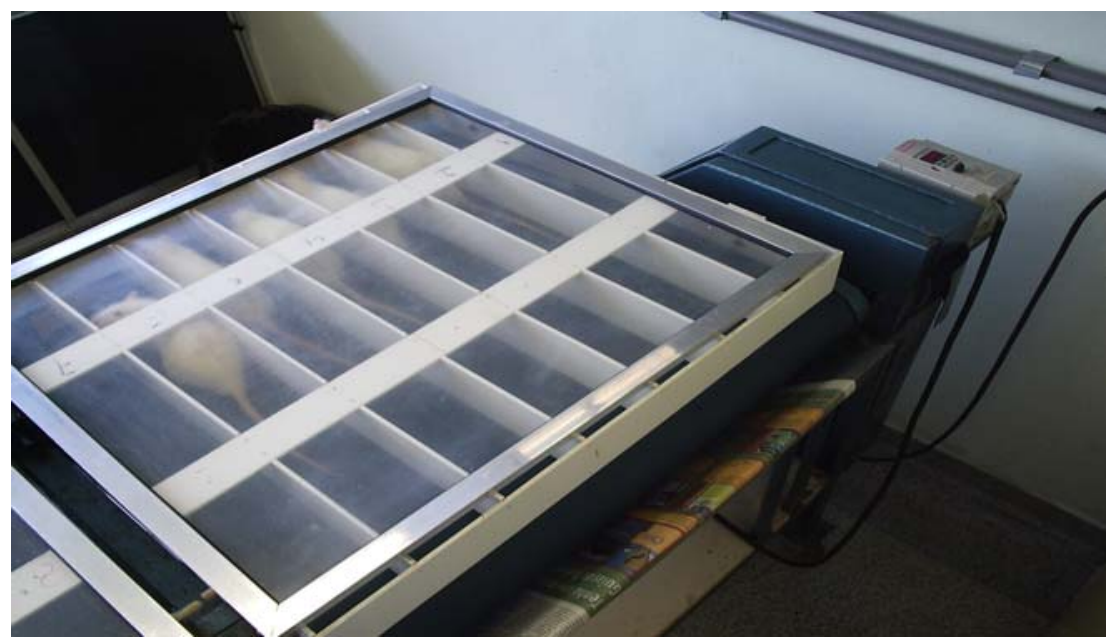

Figura 16. Esteira elétrica utilizada para o treinamento dos animais.

\subsection{Procedimento Experimental}

\subsubsection{Mecanismo de Lesão}

Neste trabalho, a produção da lesão experimental utilizada, não foi um método invasivo.

Utilizamos um modelo de lesão que pudesse caracterizar uma contusão muscular através de um agente mecânico sem ponta que se choca com segmento corporal pré estabelecido (ventre do músculo gastrocnêmio).

Para a realização da lesão foram tomados alguns cuidados em relação às técnicas de assepsia do local lesionado e do aparelho, para que agentes externos não interferissem no procedimento.

Os animais foram previamente anestesiados, e o terço médio do ventre muscular do gastrocnêmio tricotomizado, expondo da região a ser lesada (figura 17).

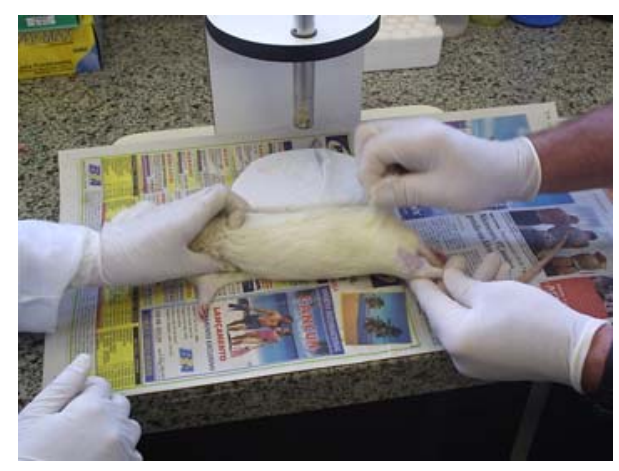

Figura 17. Demonstração da tricotomia do ventre muscular (gastrocnêmio). 
A figura 18, abaixo, mostra o posicionamento do animal em decúbito ventral, com extensão da articulação coxo-femural e joelho e, a área do músculo gastrocnêmio devidamente tricotomizada para a realização do trauma experimental.

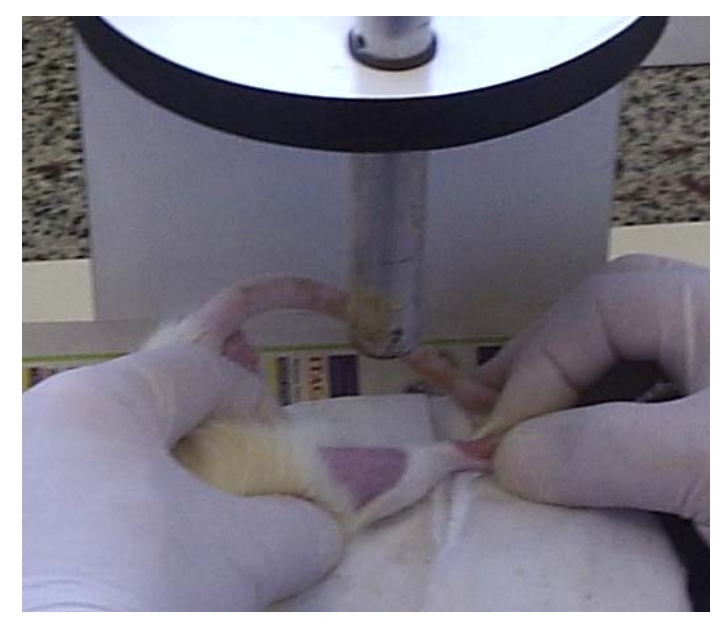

Figura 18. Posicionamento do animal antes da lesão experimental pelo peso padronizado.

O aparelho utilizado para a lesão (figura 19) foi confeccionado em madeira com uma haste de ferro que servia de guia para o curso do peso, não permitindo que este oscilasse durante a queda. Nesta haste havia perfurações na qual podíamos controlar a altura desejada para o procedimento, e o peso era solto com a retirada de um pino que o mantinha na haste. O peso utilizado foi de 200 g colocado a 30 centímetros de distância da pata do animal, sendo a energia do impacto, no sítio da lesão, de aproximadamente 294 N, segundo a fórmula adaptada por Minamoto (1999) (SENE, 2005):

$$
F=m \cdot g \cdot h \cdot \Delta S^{-1} \text { onde: }
$$

$F=$ força;

$m$ = massa;

$g$ = aceleração da gravidade;

$h$ = altura da liberação da carga;

$\Delta S^{-1}=$ deformação tecidual. 

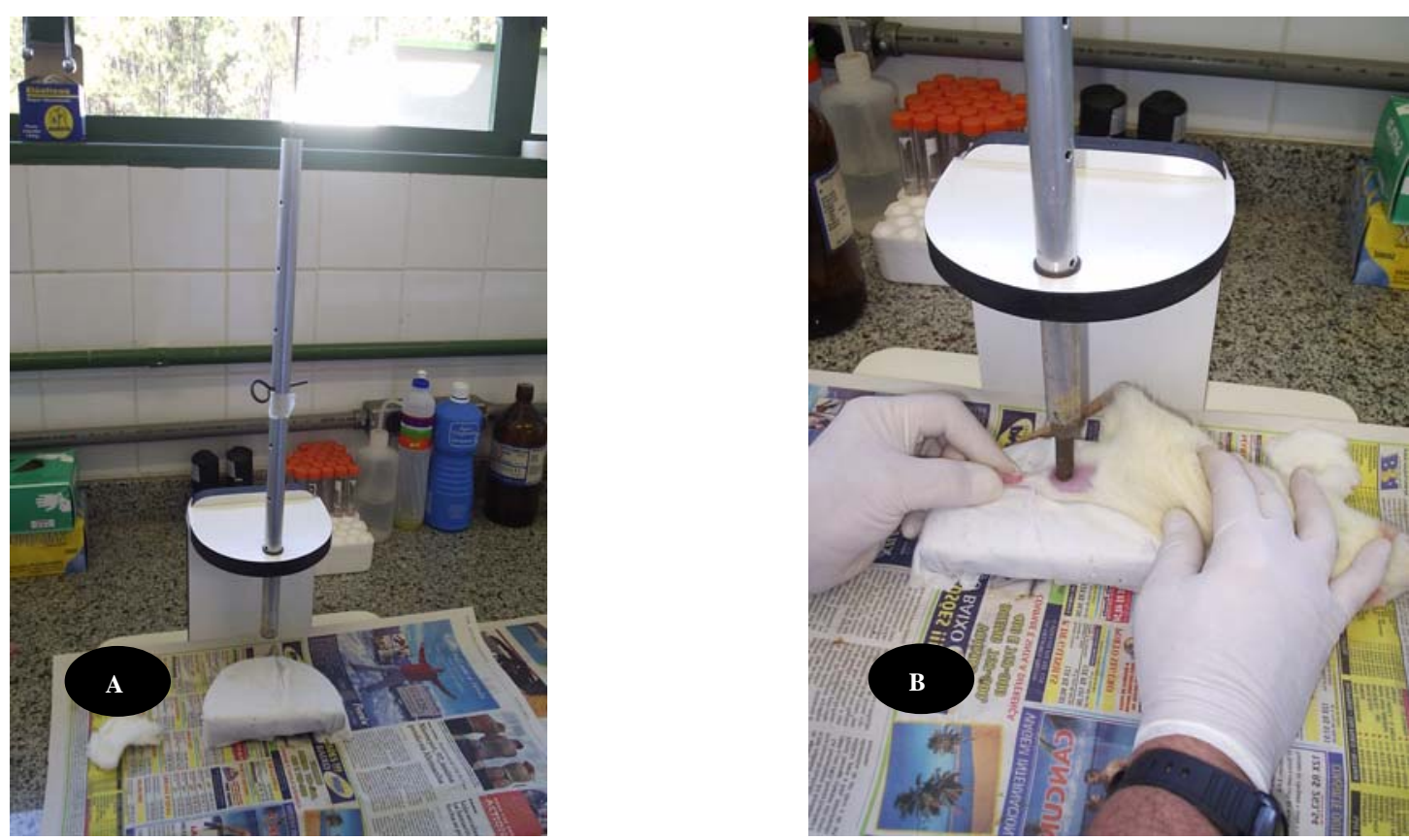

Figura 19. A seqüência das figuras A e B mostra respectivamente, o aparelho utilizado para a lesão experimental, o posicionamento do peso após a lesão.

\subsubsection{Tratamento com Ultra-som Pulsado de Baixa Intensidade}

O equipamento utilizado para a sonificação (figura 20) foi projetado e montado no laboratório de Bioengenharia da Escola de Engenharia de São Carlos, operando nos seguintes parâmetros físicos, relacionados abaixo:

Forma da Onda:

Largura do pulso:

Amplitude:

Intensidade Acústica (SATA):

Freqüência de repetição:

Freqüência do PZT-4:

Área do transdutor:
Pulsada

$200 \mu \mathrm{s}$

25V (pico a pico)

$16 \mathrm{mw} / \mathrm{cm}^{2}$

$1 \mathrm{kHz}$

$1,5 \mathrm{MHz}$

$3,8 \mathrm{~cm}^{2}$

Estes parâmetros foram verificados anteriormente ao início do tratamento mediante dosímetro de ultra-som de precisão (modelo UPM-DT10 - OHNIC). 


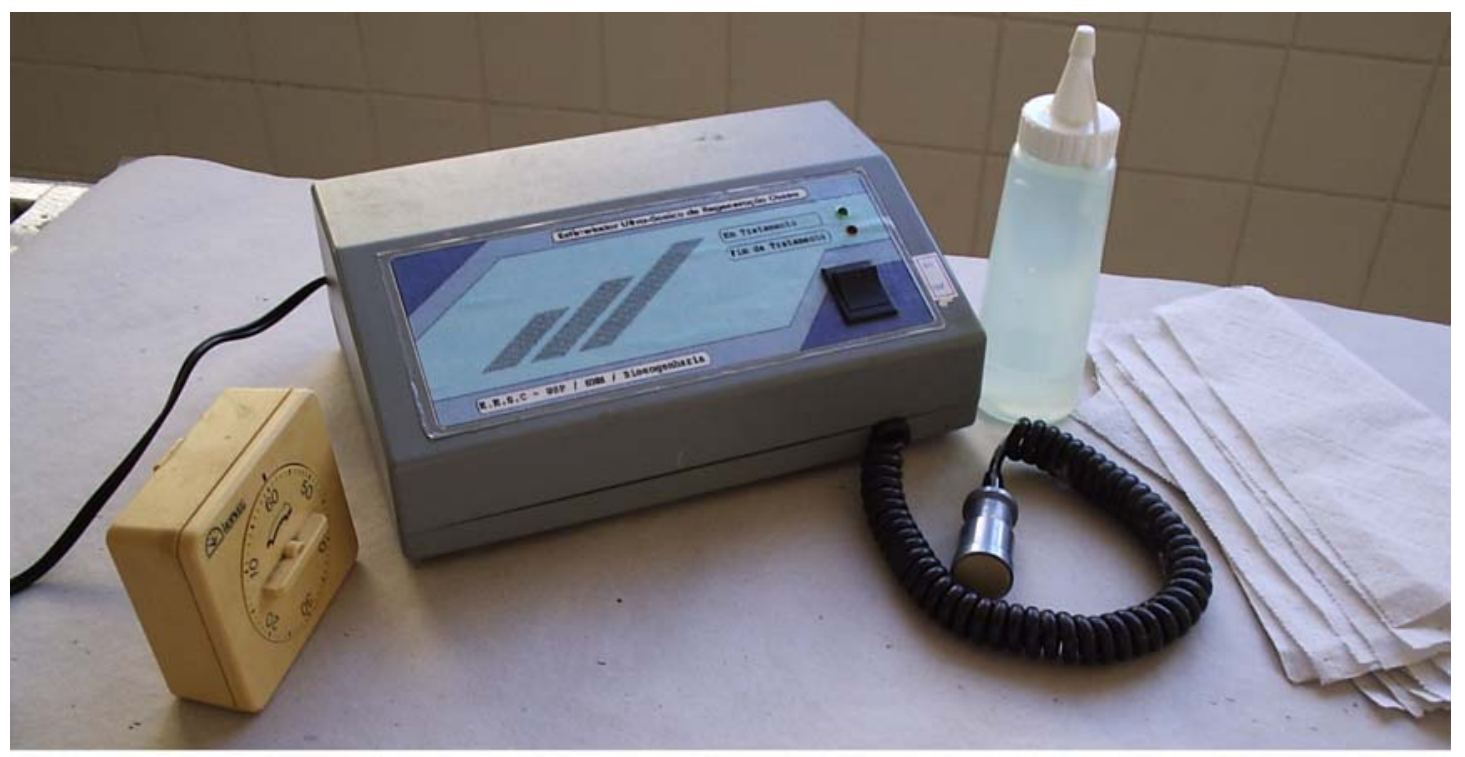

Figura 20. Equipamento utilizado para a sonificação dos animais, timer utilizado para a marcação do tempo e gel hidrossolúvel.

O tratamento com o USP (figura 20) foi iniciado 24 horas após a lesão, sendo realizado por 15 minutos diários por 3 dias consecutivos em todos os animais na pata lesada (esquerda), por via transcutânea (transdutor acoplado sobre a pele com auxílio de um gel hidrossolúvel) e de forma estacionária, tomando-se sempre o cuidado em realizar as sonificações no mesmo período do dia.

Para a realização deste procedimento os animais foram colocados em um tubo de contenção demonstrado na figura 21.

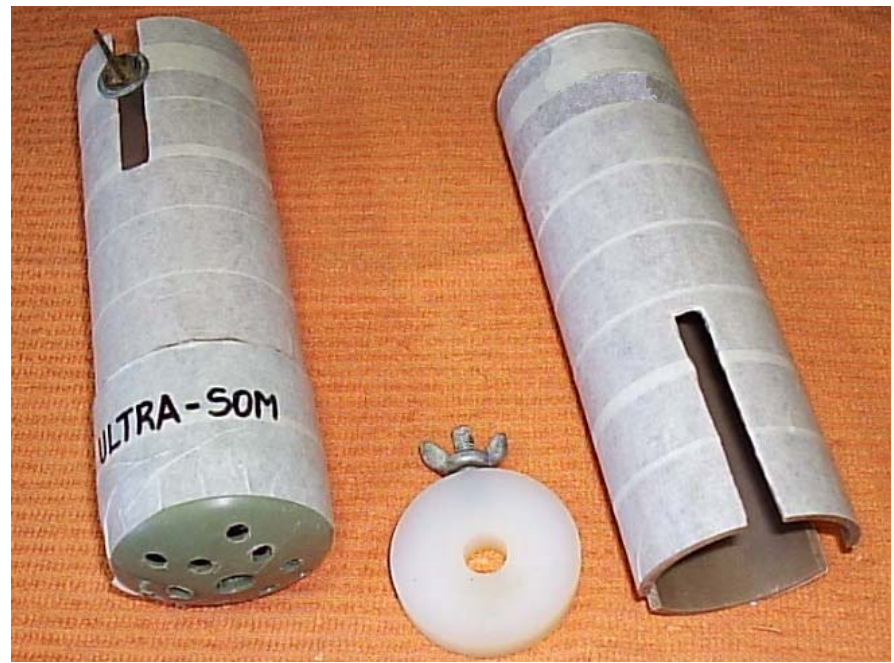

Figura 21. Tubo de contenção utilizado para a aplicação do ultra-som. 


\subsection{Sacrifício}

Decorrido o tempo estipulado de 3 dias para os estímulos ultra-sônicos (USP), todos os animais foram sacrificados com guilhotina. Os músculos gastrocnêmio e sóleo da pata direita foram retirados e congelados em nitrogênio líquido para posterior análise histoenzimológica e o músculo gastrocnêmio lesado e tratado da pata esquerda foi fixado em formol neutro para a realização do estudo histopatológico, sendo um pequeno fragmento retirado anteriormente à fixação em formol neutro para a realização de corte semi-fino, sendo este fixado em glutaraldeído.

\subsection{Obtenção dos Cortes e Análise Histoenzimológica}

Os fragmentos do músculo gastrocnêmio das áreas de impacto (pata esquerda) foram retirados cirurgicamente após o sacrifício dos animais para a realização de cortes histológicos, para se determinar a regeneração tecidual nesta área. Estes fragmentos, foram fixados em formol neutro por 5 dias e a seguir incluídos em parafina, cortados com espessura de $5 \mu \mathrm{m}$, desparafinizados e corados em Hemalumen-eosina (H.E.) e Tricrômico de Gomori.

Antes que os fragmentos da área de impacto fossem fixados em formol neutro, um pequeno fragmento foi retirado da mesma região e fixado em glutaraldeído por

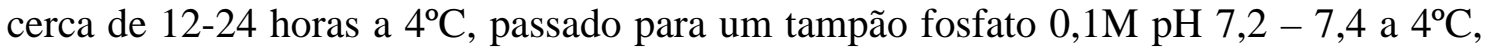
por um período de 72 horas, a seguir passaram pelas etapas de preparação padrão para a inclusão em plástico e para então, ser obtidos cortes semi-finos das fibras com 1mm de espessura corados com Azul de Toluidina.

Para o processamento das reações histológicas e histoenzimológicas foi retirado pequeno fragmento sempre do terço médio do músculo gastrocnêmio e do músculo sóleo da pata direta dos animais dos 4 grupos. Os fragmentos foram congelados em nitrogênio líquido e cortados em criótomo (Tissue-Tek ${ }^{\circledR}$ Crio $^{\circledR} 3$ ). Obtidos os cortes transversos com espessura de $5 \mu \mathrm{m}$, estes foram colhidos sobre lamínulas histológicas de 20x20 mm e expostos ao ar para desidratação. A seguir, o material foi mantido em congelador para a adesão dos cortes sobre as lamínulas, até o dia seguinte, quando iniciava-se o processamento das reações. 
Nesse estudo, para os cortes transversos utilizou-se as lâminas coradas pela Hematoxilina-eosina (H.E.) e histoenzimologia para mATPases em pH 9.4, 4.6 e 4,3 (DUBOWITZ, 1985) para a identificação dos diferentes tipos de fibras musculares, possibilitando a análise individual qualitativa e quantitativa de cada grupo, através de uma classificação subjetiva em claras ou escuras, para todos os 5 campos analisados (figura 23).

Foi utilizado para a análise morfométrica o Sistema Analisador de Imagens da Leica.

As imagens obtidas através de uma câmera de vídeo Leica DFC 300 FX acoplada a um microscópio de luz binocular Leica DM 2500 e conectada a um microcomputador, possibilitou a realização da contagem da área dos tipos de fibras musculares, mediante o emprego do programa Quali-View (figura 22).
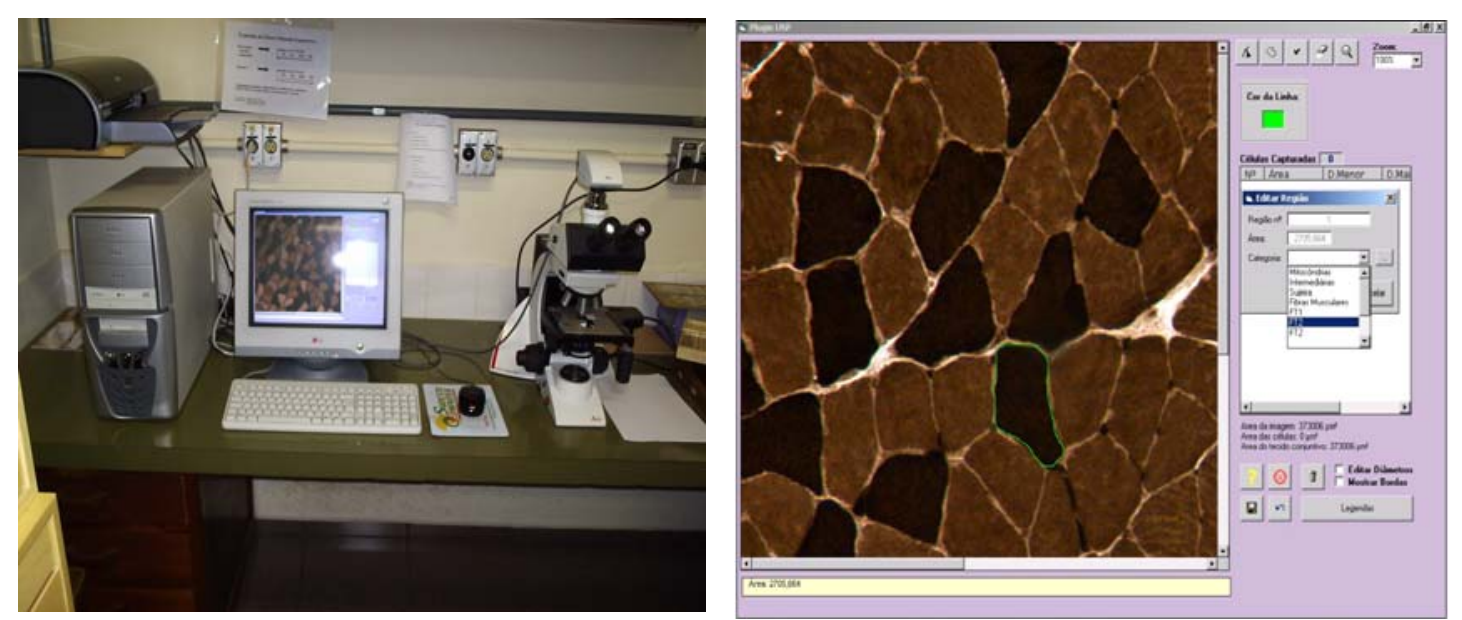

Figura 22. As fotos acima representam os equipamentos utilizados para a realização da análise morfométrica dos tipos de fibras musculares: Câmera de vídeo Leica DFC 300 FX, Microscópio de luz binocular Leica DM 2500, Microcomputador, Programa QualiView. 

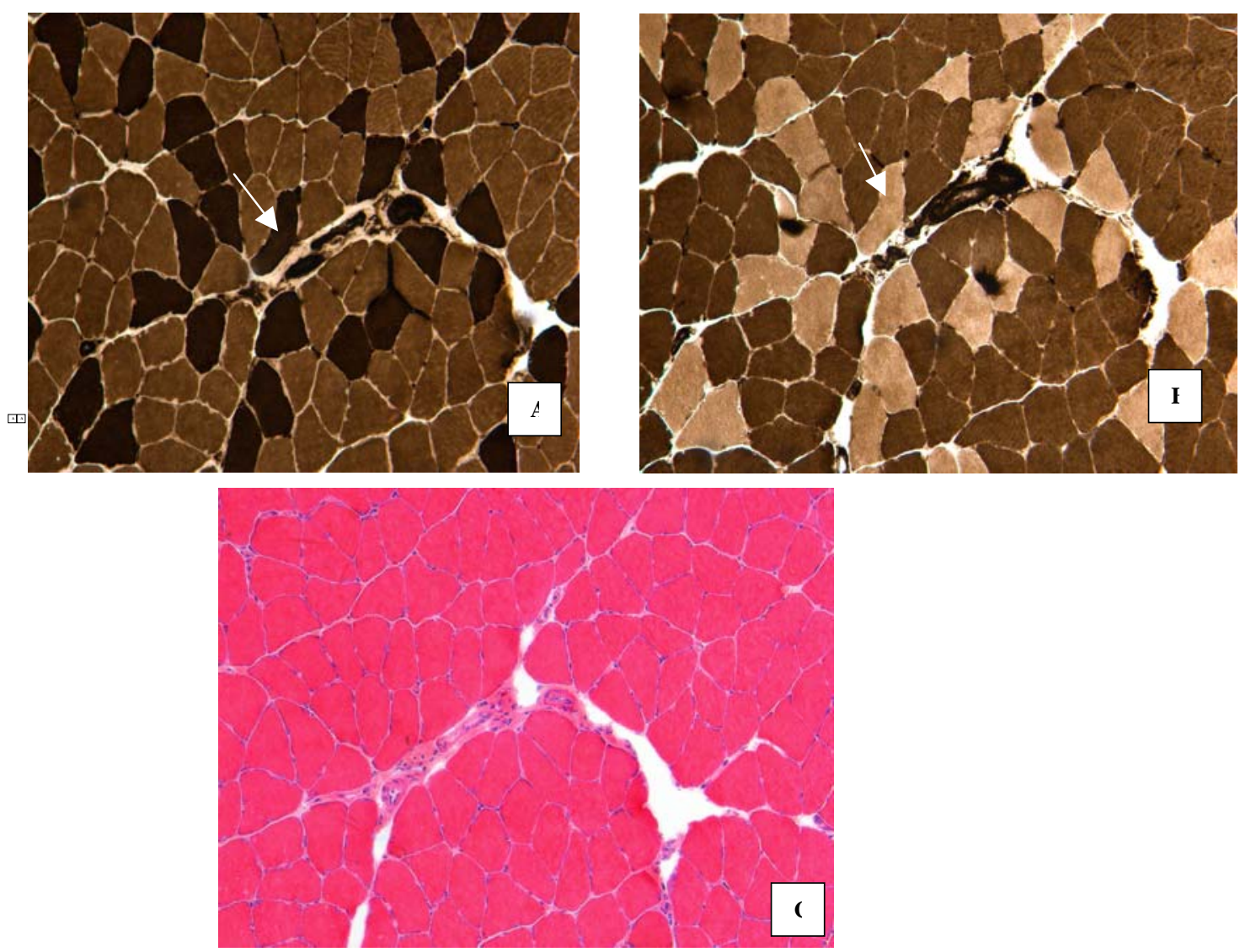

Figura 23. As fotos A e B representam cortes de reações histoenzimológicas do músculo gastrocnêmio nos pHs 9,4 e 4,6 respectivamente (as setas indicam a diferenciação em fibras claras e escuras das mesmas fibras musculares em pHs diferentes) e a foto $\mathrm{C}$ mostra o mesmo corte acima, corado com H.E.

\subsection{Análise Estatística}

Realizamos a verificação da área correspondente a mais ou menos 100 fibras musculares de cada tipo (tipo I e II) dos 4 grupos experimentais, com a ajuda do programa de computador QualiView. Aplicamos o teste estatístico de normalidade, Shapiro-Wilk $(\mathrm{p}<0,05)$, com auxílio do programa Statistica para verificarmos se a área das fibras musculares apresentavam uma distribuição normal, para então justificarmos a utilização do teste paramétrico, teste "t de student”, para a comparação entre os grupos experimentais.

Para a realização do teste "t de student”, utilizamos o programa Excel, com nível de significância $(\mathrm{p}<0,01)$. 


\section{RESULTADOS}

Os resultados serão expostos obedecendo aos eventos realizados de acordo com a proposta inicial do trabalho.

Convencionamos conduzir o experimento de modo que pudéssemos demonstrar os efeitos do álcool sobre a musculatura esquelética de animais treinados e não treinados, bem como a ação do ultra-som pulsado de baixa intensidade sobre uma contusão muscular padronizada obtida por impacto direto.

Para demonstrarmos os efeitos do álcool e do treinamento sobre a musculatura esquelética realizamos a contagem das áreas dos tipos de fibra muscular, através da análise da histoenzimologia do músculo gastrocnêmio e do músculo sóleo. Para tanto, delineamos a área de mais ou menos 100 fibras musculares de cada tipo (tipo I e II), com a ajuda do programa de computador QualiView. Aplicamos o teste de normalidade Shapiro-Wilk, com $\mathrm{p}<0.05$, para verificarmos se a área das fibras musculares (população) apresentava uma distribuição normal, e então podermos justificar a utilização do teste paramétrico, teste “t de student”, para a comparação entre os diferentes grupos experimentais, com nível de significância $\mathrm{p}<0,01$.

\section{Análise das áreas dos tipos de fibras musculares, nos músculos sóleo e gastrocnêmio, dentre os diferentes grupos experimentais.}

As figuras 24, 25, 26, e 27 apresentam os gráficos referentes à análise estatística simultânea da área dos dois tipos de fibras musculares encontradas nos músculos esqueléticos, gastrocnêmio e sóleo, e as demais variáveis dos grupos experimentais, como a ingestão ou não de bebida alcoólica e a realização ou não de treinamento físico e as tabelas 03 e 04 os valores obtidos nesta análise. 
Músculo Sóleo

Animais Sedentários

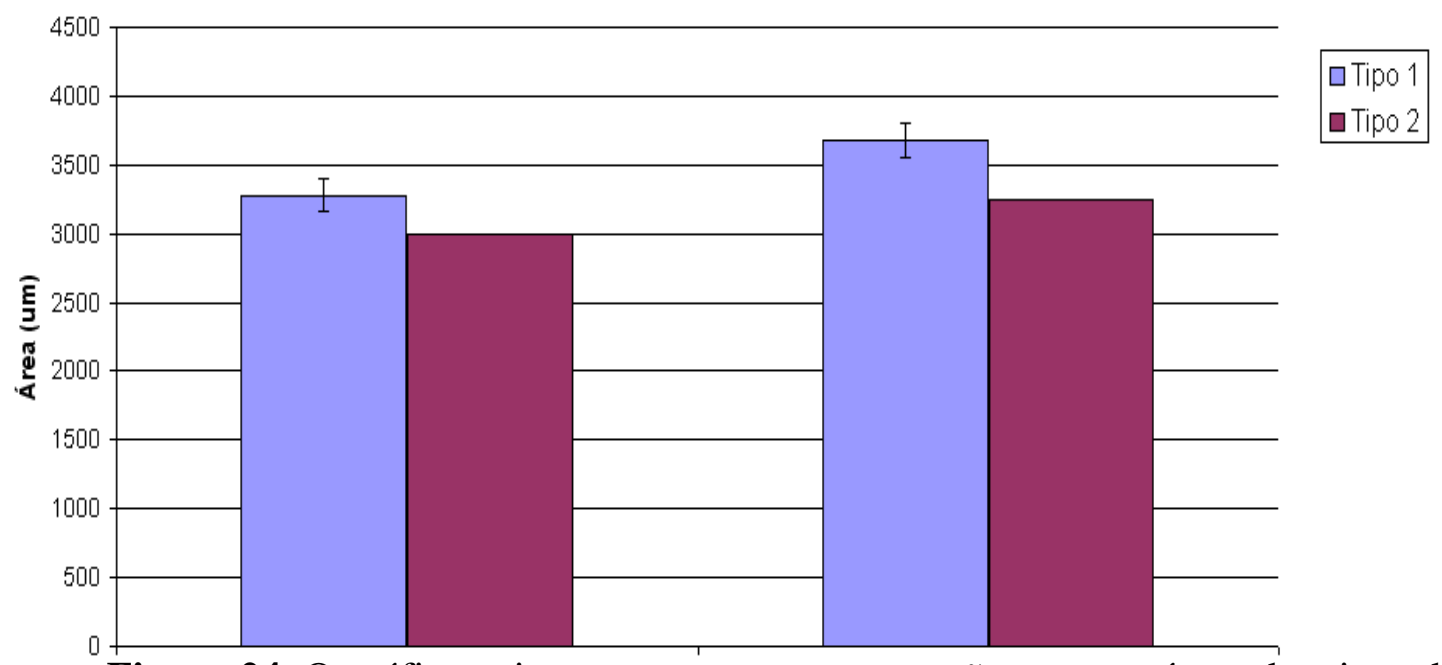

Figura 24. O gráfdico acima representa a comparaçãđaa entre as áreas dos tipos de fibras, I e II, e as variáveis; ingestão de álcool e água, nos animais sedentários, no músculo sóleo.

\section{Músculo Sóleo}

Animais Treinados

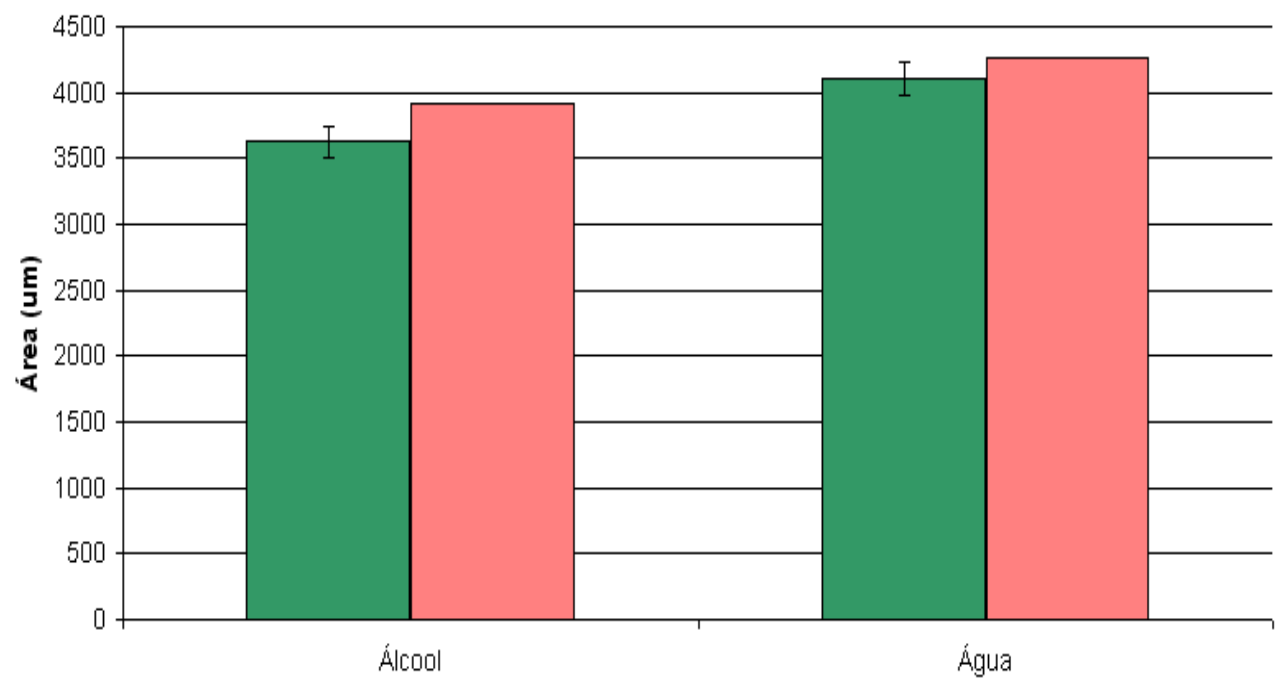

Figura 25. O gráfico acima representa a comparação entre as áreas dos tipos de fibras, I e II, e as variáveis; ingestão de álcool e água, nos animais treinados, no músculo sóleo. 


\begin{tabular}{|c|c|c|c|c|}
\hline Sóleo & \multicolumn{2}{|c|}{ Sedentário } & \multicolumn{2}{c|}{ Treinado } \\
\hline & Álcool & Água & Álcool & Água \\
\hline Erro-padrão & 117,4509 & 124,4049 & 168,6262 & 168,4911 \\
\hline Média do tipo I & 3275,12 & 3673,468 & 3627,551 & 4107,051 \\
\hline $\begin{array}{c}\text { Média do tipo } \\
\text { II }\end{array}$ & 2997,027 & 3252,426 & 3913,002 & 4257,896 \\
\hline P < 0,01 & $3,7710-6$ & $4,9510-11$ & $0,9210-3$ & 0,078703 \\
\hline & Significativo & Significativo & Significativo & $\begin{array}{c}\text { Não } \\
\text { Significativo }\end{array}$ \\
\hline
\end{tabular}

Tabela 04. Valores obtidos com a comparação entre as áreas dos tipos de fibras tipo I e II no músculo sóleo, e as variáveis; a ingestão de álcool ou água, e animais treinados e sedentários.

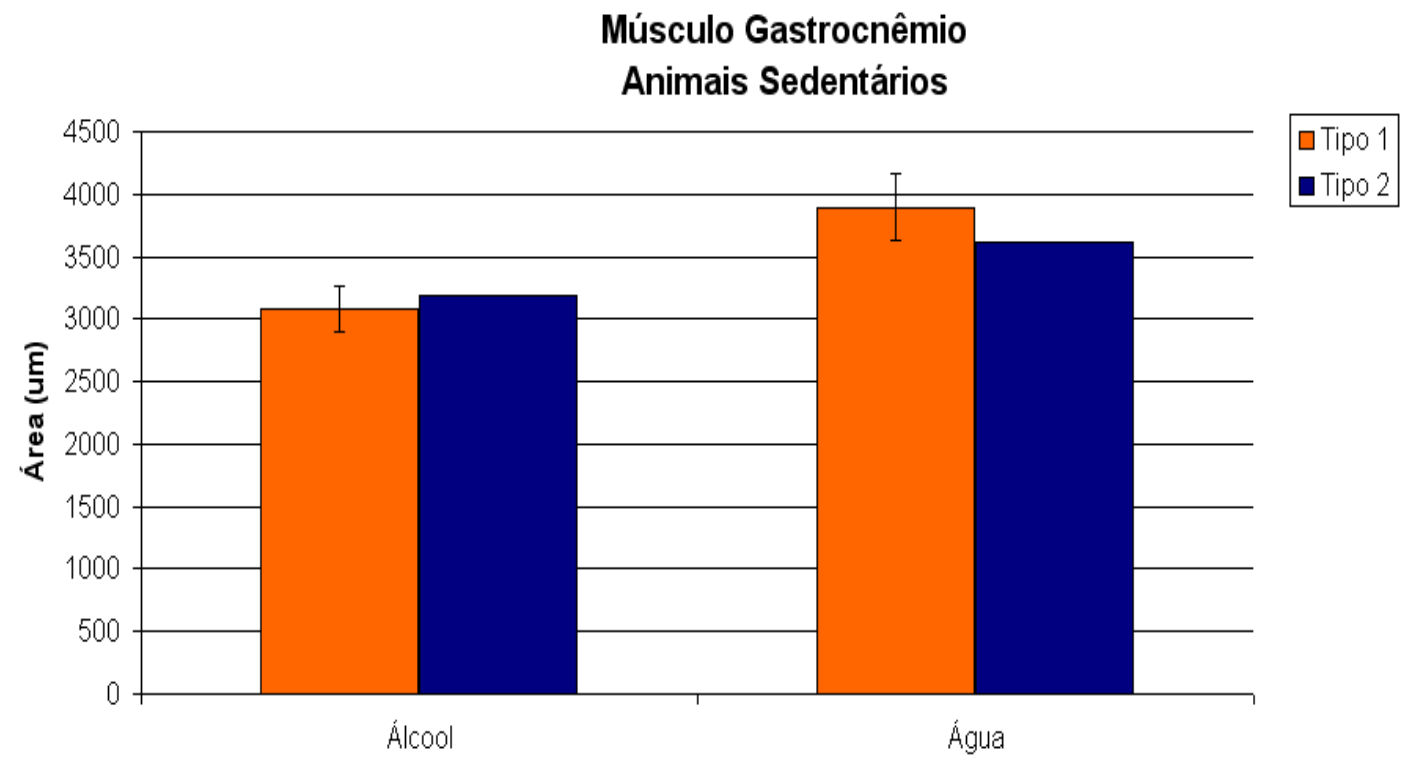

Figura 26. O gráfico acima representa a comparação entre as áreas dos tipos de fibras, I e II, e as variáveis; ingestão de álcool e água, nos animais sedentários, no músculo gastrocnêmio. 


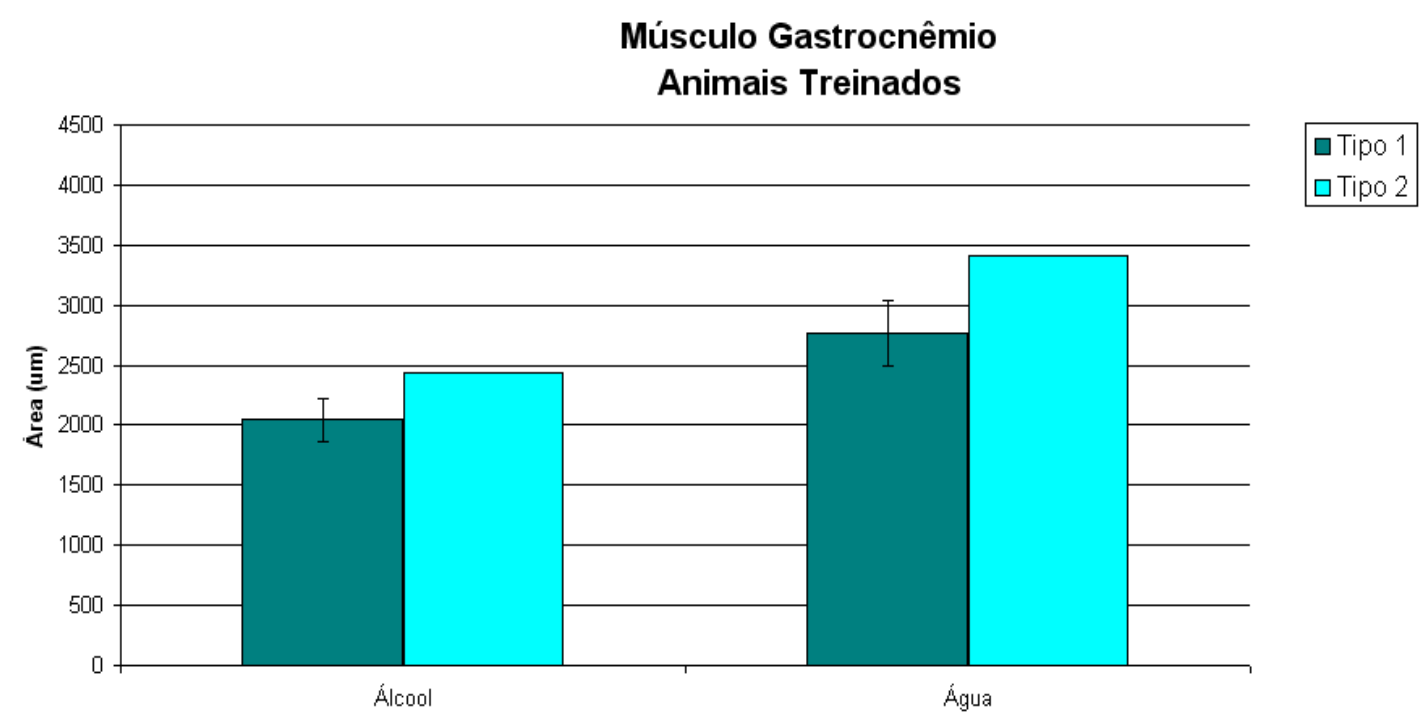

Figura 27. O gráfico acima representa a comparação entre as áreas dos tipos de fibras, I e II, e as variáveis; ingestão de álcool e água, nos animais treinados, no músculo gastrocnêmio.

\begin{tabular}{|c|c|c|c|c|}
\hline Gastrocnêmio & \multicolumn{2}{|c|}{ Sedentário } & \multicolumn{2}{c|}{ Treinado } \\
\hline & Álcool & Água & Álcool & Água \\
\hline Erro-padrão & 180,4047 & 266,9093 & 91,23619 & 134,7416 \\
\hline Média do tipo I & 3077,941 & 3891,229 & 2044,14 & 2764,345 \\
\hline Média do tipo II & 3188,817 & 3619,122 & 2438,171 & 3404,4 \\
\hline P < 0,01 & 0,22699 & 0,045476 & $8,1510-17$ & $8,1310-20$ \\
\hline & $\begin{array}{c}\text { Não } \\
\text { Significativo }\end{array}$ & $\begin{array}{c}\text { Não } \\
\text { Significativo }\end{array}$ & Significativo & Significativo \\
\hline
\end{tabular}

Tabela 05. Valores obtidos com a comparação entre as áreas dos tipos de fibras tipo I e II no músculo gastrocnêmio, e as variáveis; a ingestão de álcool ou água, e animais treinados e sedentários. 
Quando comparamos simultaneamente os grupos treinados com os sedentários e as demais variáveis, observamos um aumento na área das fibras musculares tipo I e tipo II, em todos os grupos treinados, tanto dos que ingeriram álcool, como os que ingeriram água, sendo esta diferença significativa $(\mathrm{p}<0,01)$, figuras 28 e 29 ..

\section{Músculo Sóleo}

Tipo 1

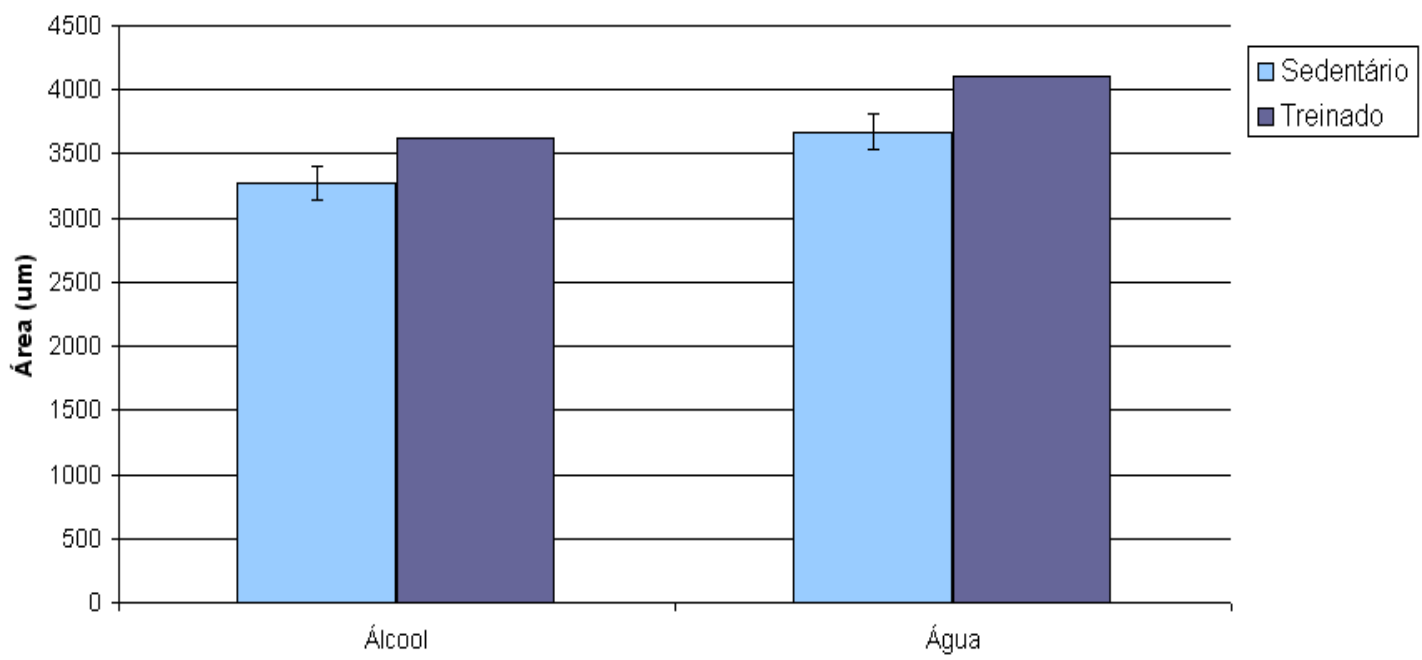

Figura 28. O gráfico acima representa a comparação entre os animais sedentários e treinados, e as variáveis; ingestão de álcool e água e tipo de fibra I, no músculo sóleo.

\section{Músculo Sóleo}

Tipo 2

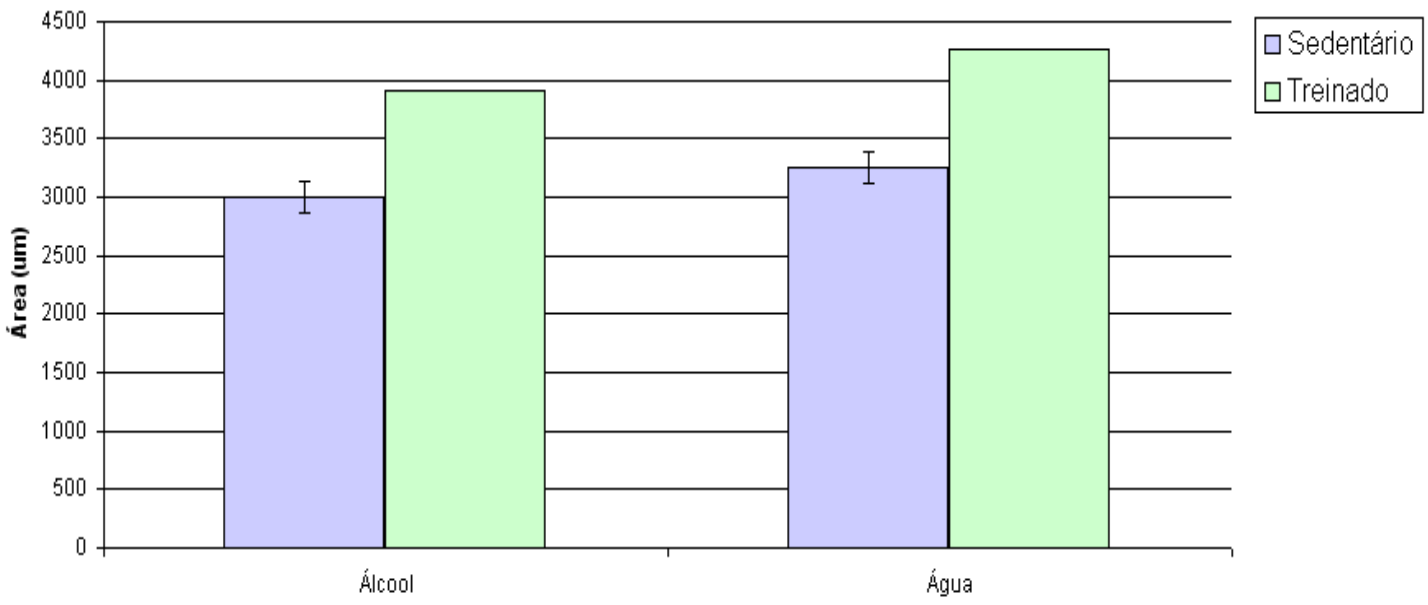

Figura 29. O gráfico acima representa a comparação entre os animais sedentários e treinados, e as variáveis; ingestão de álcool e água e tipo de fibra II, no músculo sóleo. 


\begin{tabular}{|c|c|c|c|c|}
\hline Sóleo & \multicolumn{2}{|c|}{ Tipo 1 } & \multicolumn{2}{c|}{ Tipo 2 } \\
\hline & Álcool & Água & Álcool & Água \\
\hline Erro-padrão & 130,7719 & 141,2329 & 158,4983 & 154,6606 \\
\hline $\begin{array}{c}\text { Média dos } \\
\text { sedentários }\end{array}$ & 3275,12 & 3673,47 & 2997,03 & 3252,43 \\
\hline $\begin{array}{c}\text { Média dos } \\
\text { treinados }\end{array}$ & 3627,55 & 4107,05 & 3913,00 & 4257,90 \\
\hline $\mathbf{P}<\mathbf{0 , 0 1}$ & $1,4710-7$ & $2,3110-9$ & $7,1710^{-27}$ & $6,6110^{-33}$ \\
\hline & Significativo & Significativo & Significativo & Significativo \\
\hline
\end{tabular}

Tabela 06. Valores obtidos com a comparação entre animais treinados e sedentários, e as variáveis; ingestão de álcool e água e tipo de fibras I e II, no músculo sóleo.

Quando realizamos a análise simultânea entre os animais que ingeriram ou não aguardente de cana (álcool) com as demais variáveis, verificamos um aumento significativo na área das fibras musculares dos tipos I e II, nos animais treinados e sedentários, como representado nas figuras 30 e $31 .$.

Músculo Gastrocnêmio

Tipo 1

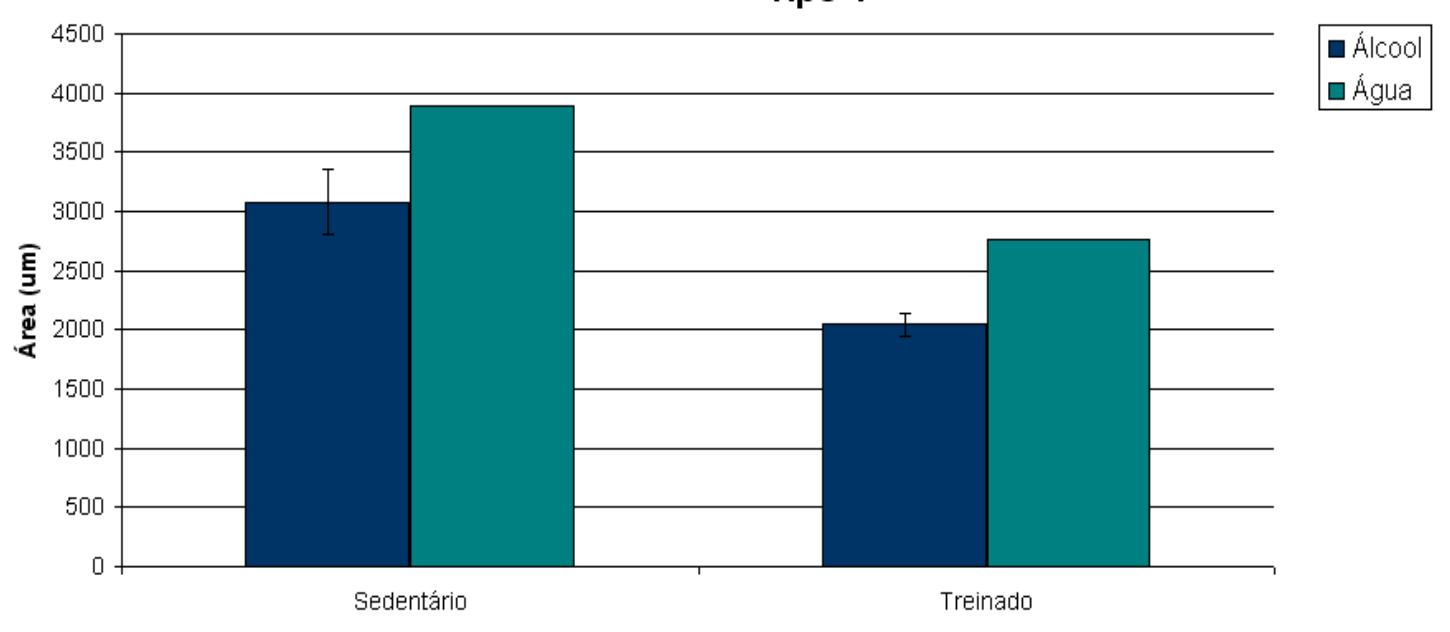

Figura 30. O gráfico acima representa a comparação entre os animais que ingeriram água ou álcool e as variáveis treinado e sedentário e o tipo de fibra I, no músculo gastrocnêmio. 


\section{Músculo Gastrocnêmio \\ Tipo 2}

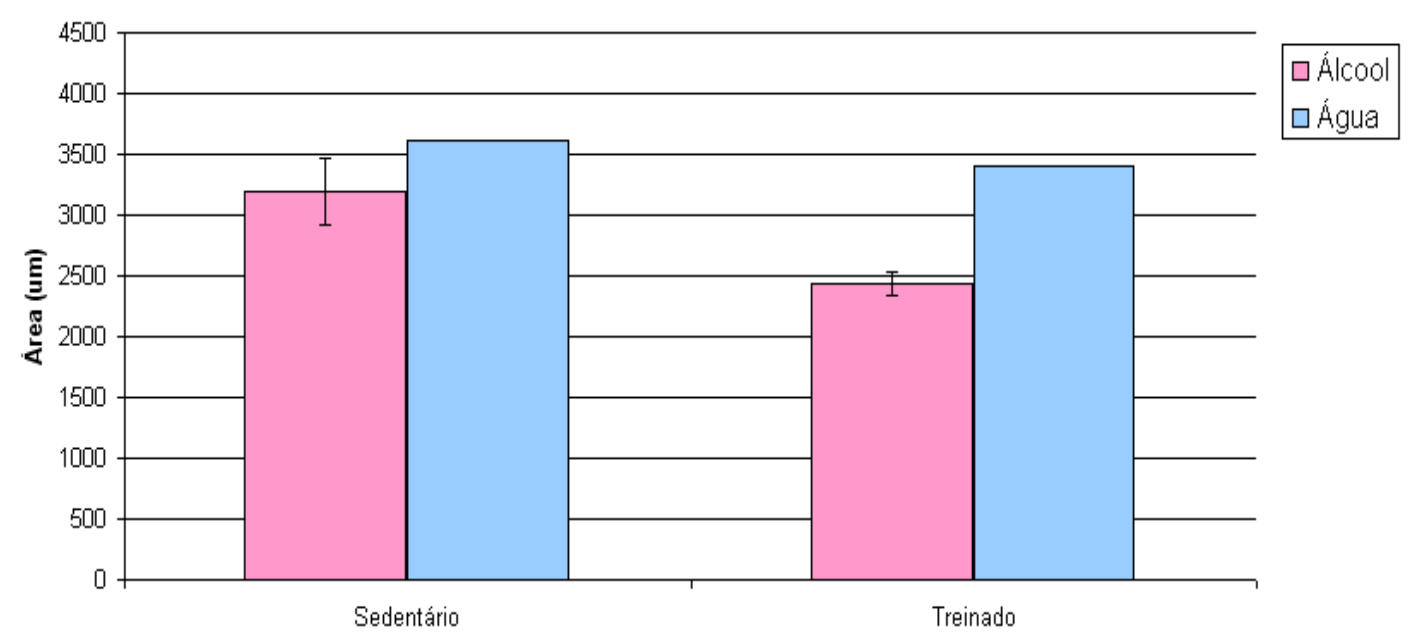

Figura 31. O gráfico acima representa a comparação entre os animais que ingeriram água ou álcool e as variáveis treinado e sedentário e o tipo de fibra II, no músculo gastrocnêmio.

\begin{tabular}{|r|r|r|r|r|}
\hline Gastrocnêmio & \multicolumn{2}{|c|}{ Tipo 1 } & \multicolumn{2}{c|}{ Tipo 2 } \\
\hline & \multicolumn{1}{|c|}{ Sedentário } & \multicolumn{1}{c|}{ Treinado } & \multicolumn{1}{c|}{ Sedentário } & \multicolumn{1}{c|}{ Treinado } \\
\hline Erro-padrão & 275,0816 & 101,1426 & 167,691 & 127,3821 \\
\hline Média Álcool & 3077,941 & 2044,14 & 3188,817 & 2438,171 \\
\hline Média Água & 3891,229 & 2764,345 & 3619,122 & 3404,4 \\
\hline $\mathbf{P}<\mathbf{0 , 0 1}$ & $1,0210-8$ & $1,9810-39$ & $5,610^{-7}$ & $9,0810-15$ \\
\hline & Significativo & Siønificativo & Significativo & Siønificativo \\
\hline
\end{tabular}

Tabelo 07. Valores obtidos com a comparação entre animais que ingeriram água ou álcool e as variáveis treinado e sedentário e os tipo de fibras I e II, no músculo gastrocnêmio. 
A região da lesão muscular obtida por impacto direto sobre o ventre do músculo gastrocnêmio esquerdo foi documentada através de fotomicrografias (câmera de vídeo

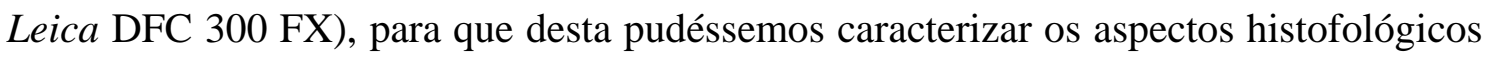
da evolução da lesão muscular associada à estimulação com ultra-som pulsado de baixa intensidade (USP) por 3 dias consecutivos, nos animais dos quatro grupos experimentais.

O processo de cicatrização dos tecidos segue, comumente, 3 fases: a fase inflamatória ou inicial, a fase fibroblástica ou de proliferação e a fase de remodelamento ou maturação, sendo que estas fases ocupam extensões variáveis no tempo e podem se sobrepor, como já relatado anteriormente.

No grupo I (alcoólatras sedentários) identificamos um grande infiltrado inflamatório, com características possivelmente induzidas pela ação do ultra-som pulsado de baixa intensidade (USP). Observamos também, regiões com hemorragia, necrose celular, fragmentação intrafibrilar e locais com neoformação de vasos sanguíneos.

Na figura 32, podemos observar os sinais dos danos causados, após a lesão por impacto e algumas características do processo inflamatório produzido pela atuação do USP, sob o tecido muscular lesionado do grupo I.

No grupo III (Alcoólatras treinados) observamos um aumento do infiltrado inflamatório no espaço intersticial em comparação com o do grupo I, demonstrando um aumento da regeneração em fase inflamatória, possivelmente devido ao trauma nas fibras musculares sensibilizadas pelo álcool e pelo treinamento físico, como também, devido ao estímulo do USP. Verificamos também nestes animais, necrose, fragmentação intrafibrilar e lise intracelular, áreas com hemorragia, neoformação de vasos sangüíneos e aumento na quantidade de núcleos periféricos na fibra, quando comparados com os do grupo I (Figura 33). 

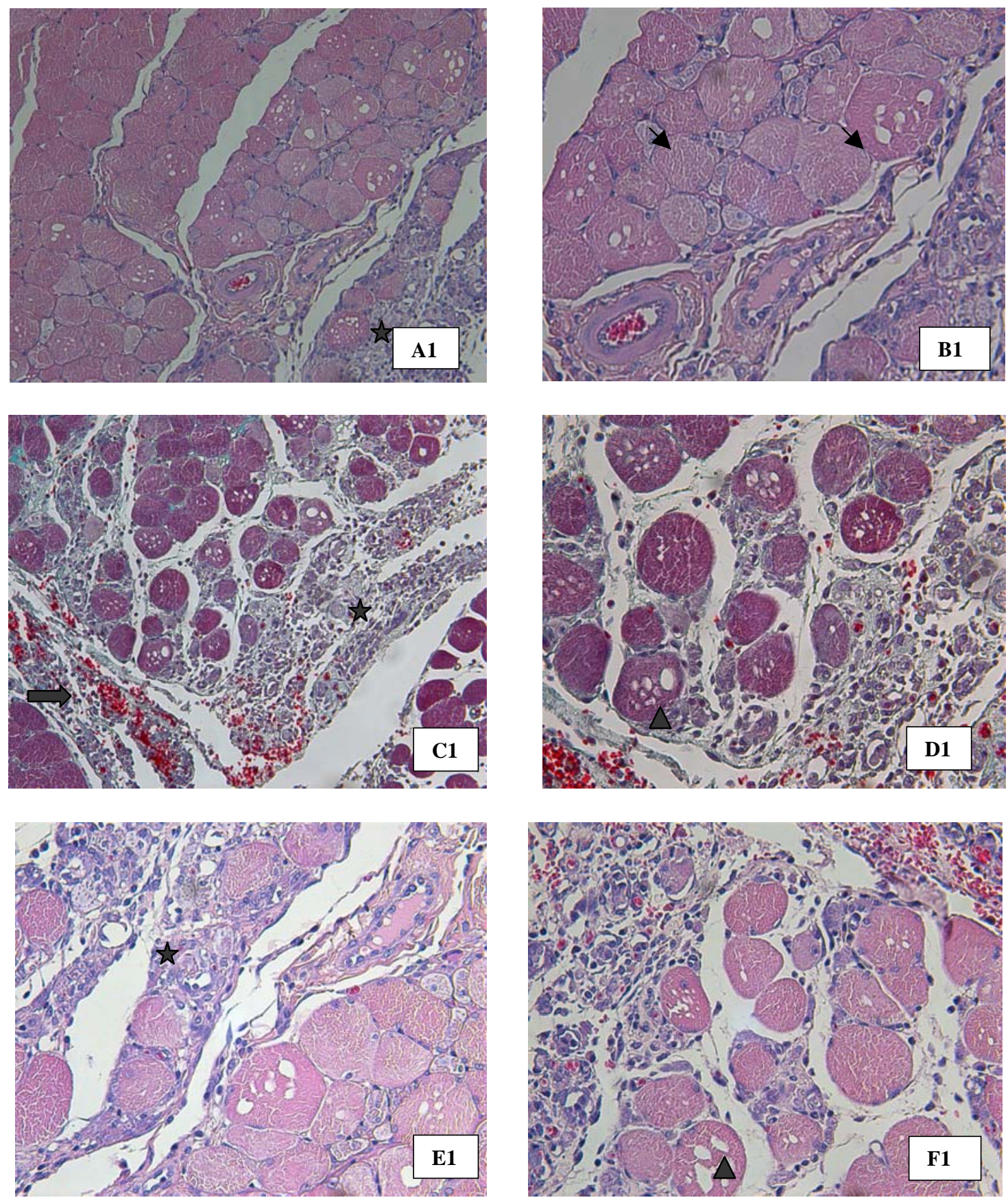

Figura 32. A seqüência de fotomicrografias A1, B1, C1, D1, E1 e F1, representam os aspectos histológicos do corte transversal do músculo gastrocnêmio esquerdo do grupo I (alcoólatra sedentário): (A1, CI e E1) Infiltrado inflamatório, corado com Hemalumem-eosina (H.E.) A1 e E1, em Tricrômico de Gomori C1 (estrela), (B1) Fragmentação intracelular em H.E. (seta), (C1) Área de hemorragia em Tricrômico de Gomori (seta grossa), (D1 e F1) Necrose da fibra muscular, em H.E. (cabeça de seta). (Aumento de cax respectivamente 20x e 40x). 
Os animais do grupo II (controles sedentários) exibiram uma redução sensível do processo inflamatório, quando comparado aos músculos dos animais do grupo I, com restritas áreas com pequenos focos de hemorragia e fragmentação intrafibrilar, com aspecto melhor quando comparado aos animais grupo I e, pior aspecto, quando comparado aos grupo IV.

Identificamos no grupo IV (controle treinado) raras áreas com a presença de pequeno infiltrado inflamatório, um aumento do número de núcleos na periferia da fibra muscular quando comparados ao grupo II e fragmentação intrafibrilar (Figura 35).

Observamos tanto no grupo II como no grupo IV áreas com neoformação de vasos sanguíneos. 

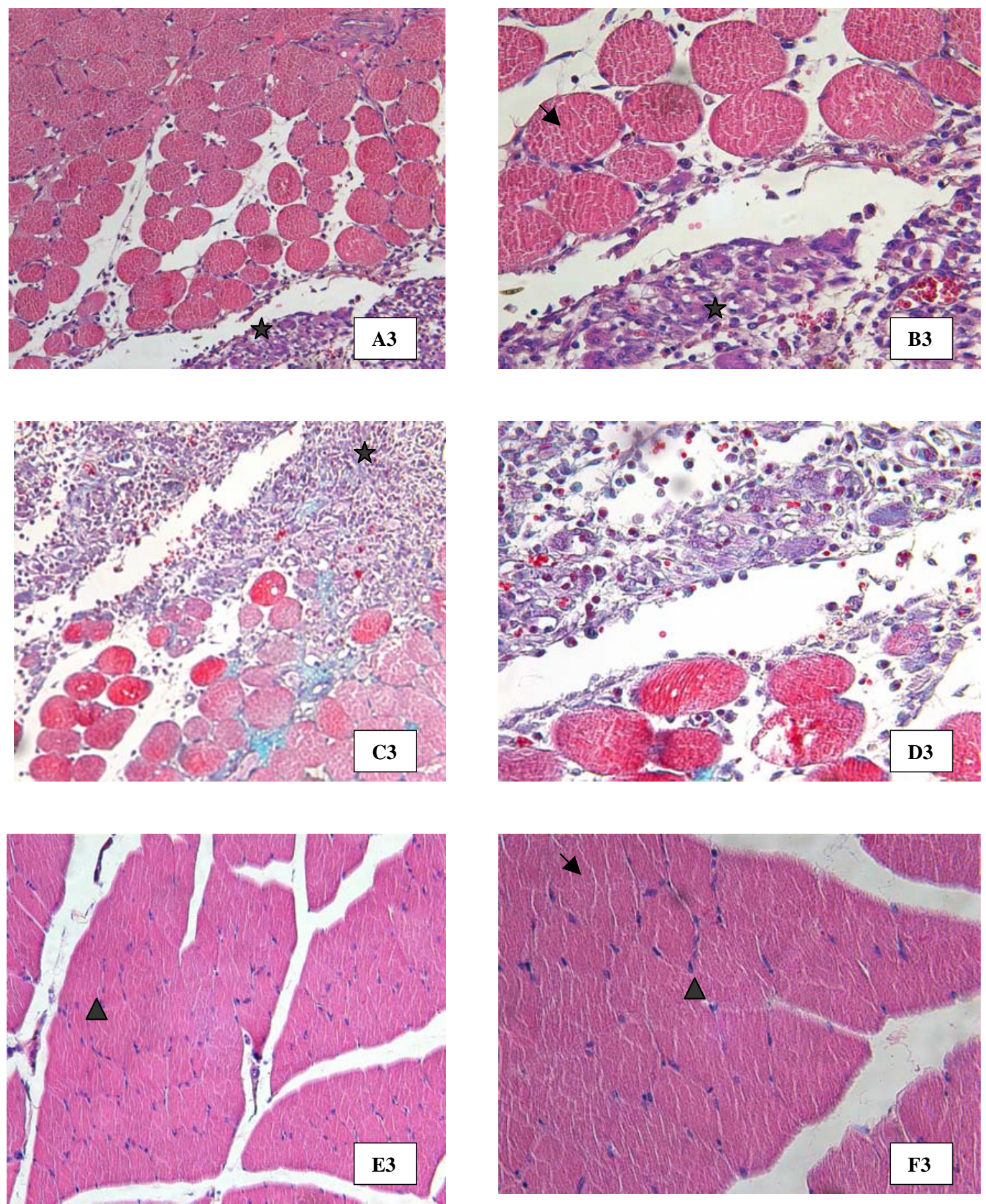

Figura 33. A seqüência de fotomicrografias A3, B3, C3, D3, E3 e F3, representam aspectos histopalógicos da fibra do músculo gastrocnêmio esquerdo, do grupo III (alcoólatra treinado): (A3, B3 e C3) Infiltrado inflamatório em Tricrômico de Gomori (estrela), (B3 e F3) Fragmentação intracelular representada na lâmina B3 corada com Tricrômico de Gomori e na lâmina F3 corada com H.E. (seta), (E3 e F3) Aumento do número de núcleos periféricos na fibra muscular, lâminas coradas em H.E. (cabeça de seta). (Aumento de cax respectivamente 20x e 40x). 

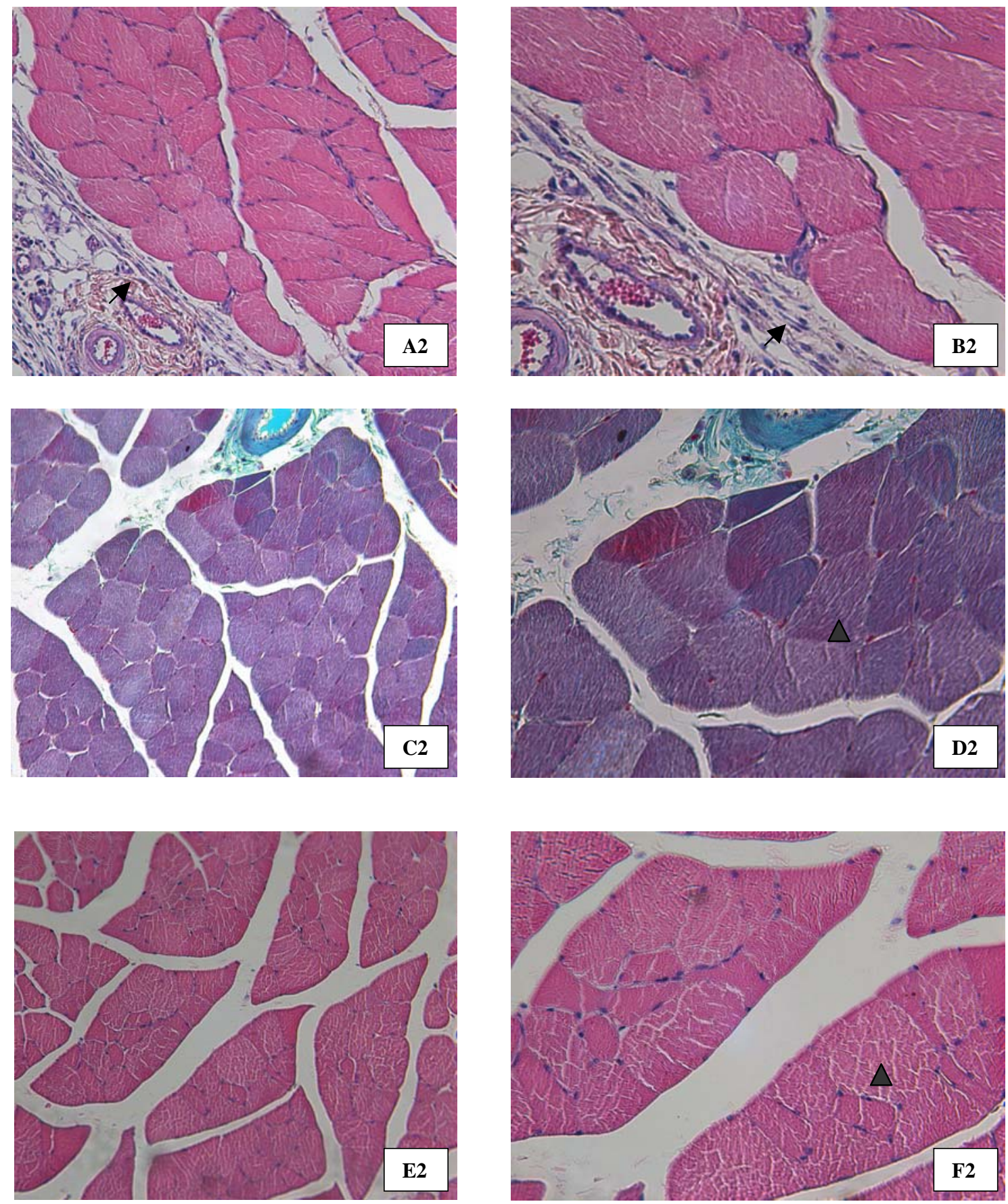

Figura 34. A seqüência de fotomicrografias A2, B2, C2, D2, E2 e F2, representam aspectos histológicos em corte transversal do músculo gastrocnêmio esquerdo do grupo II (controle sedentário): (A2 e B2) Pequeno infiltrado inflamatório, coloração H.E. (seta), (D2 e F2) Fragmentação intracelular, lâmina D2 corada em H.E. e lâmina F2 corada em Tricrômico de Gomori (cabeça de seta). (Aumento de cax respectivamente 20x e 40x). 

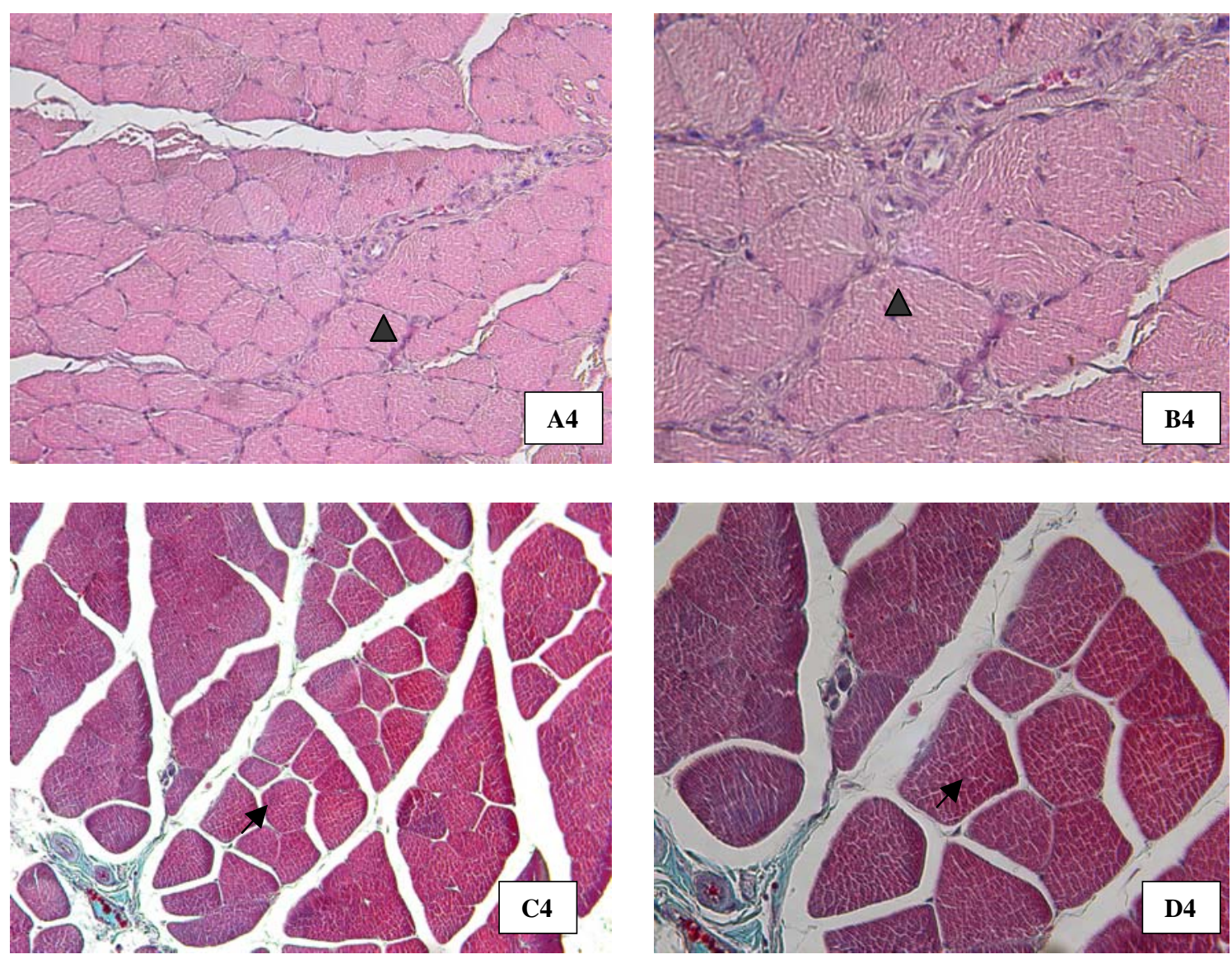

Figura 35. A seqüência de fotomigrografias A4, B4, C4, D4, acima, representa aspectos histológicos em corte transversal do músculo gastrocnêmio esquerdo, do grupo IV(controle treinado): (A4 e B4) Aumento no número de núcleos periféricos, lâminas coradas em H.E. (cabeça de seta), (C4 e D4) Fragmentação intrafibrilar, lâminas coradas em Tricrômico de Gomori (seta). (Aumento de cax respectivamente 20x e 40x). 


\section{DISCUSSÃO}

O alcoolismo é um grave problema de saúde pública, médico e social, sendo o álcool amplamente consumido de forma legal e de modo abusivo em todo o mundo.

No Brasil, de acordo com Grupo Interdisciplinar de Estudos de Álcool e Drogas (Grea) do Instituto de Psiquiatria do Hospital das Clínicas, cerca de 15\% da população brasileira é alcoólatra.

Inúmeros estudos têm demonstrado a integração entre o uso abusivo do álcool e as lesões nas fibras musculares, principalmente nas fibras tipo II, sendo que o distúrbio causado na fibra muscular é mais comum que outras patologias induzidas pelo álcool, afetando 40-60\% dos alcoólatras crônicos (PREEDY et al., 2003).

Vários animais têm sido utilizados em estudos experimentais sobre o alcoolismo crônico.

Neste trabalho optamos pela utilização de ratos Wìstar, machos por ser um animal cuja estrutura muscular assemelha-se à do homem, de fácil manuseio, baixo custo (SCHULTZ e LIPTON, 1982; PACHIONI, 1996), resistente ao consumo de álcool, diferentemente de fêmeas que são muito mais sensíveis as ações do álcool (HUNTER et al., 2003).

VILA et al. (2001) em seu trabalho utilizaram etanol diluído progressivamente de 5 para 15\%, em água, oferecido aos animais à vontade.

WORRALL et al. (2001) utilizaram o regime de Lieber-DeCarli no qual, os animais eram tratados com uma dieta liquida nutricionalmente completa contendo $35 \%$ do total de calorias, do etanol.

$\mathrm{Na}$ presente pesquisa, induzimos os animais ao alcoolismo crônico, oferecendo aguardente de cana diluída progressivamente com água, 5\% até atingir 30\%, à vontade. 
Decidimos utilizar a aguardente de cana e não o etanol puro, como a grande maioria de pesquisadores desta área, uma vez que, as bebidas consumidas pelos etilistas são uma associação de ingredientes mais o etanol e não simplesmente etanol puro e a aguardente de cana, por ser uma bebida barata, de fácil acesso, e muito consumida em nosso país.

Optamos então, estudar conseqüências de uma lesão muscular associada ao consumo de aguardente de cana, que convencionamos considerar, alcoolismo crônico, pois, segundo CRISCO et al. (1994), cerca de 90\% das lesões decorrentes da prática esportiva relatadas, são contusões musculares e estriramentos. MARKERT et al. (2005) consideram as contusões musculares muito comuns em atletas e não atletas, sendo a maioria tratadas com recursos fisioterápicos e raramente necessitam de hospitalização, o que justifica também a utilização do ultra-som, uma vez que este recurso terapêutico é amplamente utilizado dentro da prática clínica fisioterapêutica.

O estudo do trauma muscular que utilizamos, foi possível mediante o emprego de um aparelho experimental o qual promovia um impacto controlado direto no músculo de forma não-invasiva, segundo o modelo adaptado de MINAMOTO et al. (1999).

Após o trauma, decidimos pela utilização do ultra-som pulsado de baixa intensidade, já que este tem sido amplamente empregado no tratamento de regeneração das lesões musculares de diversas naturezas (BASSOLI, 2001; OLIVEIRA, 2005; MARKERT et al, 2005), como também na regeneração de diversos outros tecidos (DUARTE, 1987; ALVES, 1988; CRISCI, 2001).

Há evidencias que também a prática de atividades físicas é eficaz na resolução de uma contusão no músculo esquelético (GREGORY et al., 1995, WANEK \& SNOW, 2000).

Razões que nos levaram também, avaliar experimentalmente a aplicação de exercícios físicos e lesões padronizadas para avaliação das conseqüências sobre a musculatura esquelética de ratos submetidos ou não alcoolismo crônicos, e posteriormente avaliar efeitos do USP de baixa intensidade sobre as lesões musculares produzidas experimentalmente. 
Para a realização da contusão muscular, escolhemos o músculo gastrocnêmico, por ser este um dos músculos, que no homem, apresenta elevados índices de lesão durante a prática desportiva, razão pela qual, também convencionamos somar atividades físicas na recuperação das lesões (JARVINEN et al., 2000).

A bioestimulação ultra-sônica teve início depois de completado o período préestabelecido de treinamento de 12 semanas adaptado do protocolo de VILA et al. (2001), que estudaram a interação entre o alcoolismo e a atividade física.

Decorrido 24 horas da produção da lesão por impacto padronizada, realizamos a estimulação com o USP.

A estimulação ultra-sônica foi realizada por um período de 3 dias consecutivos, para verificar a fase aguda da regeneração e por 15 minutos, tempo bom para aplicação do USP, segundo ALBERTIN (1983). Após 96 horas decorridas da produção das lesões, os animais foram sacrificados e os músculos gastrocnêmio dos membros inferiores, direito e esquerdo e os músculos sóleo do membro inferior direito foram retirados para nosso estudo.

O período decorrente entre a produção da lesão até o sacrifício (96 horas após a lesão) foi determinado, pois, é neste momento que a proliferação de células satélites declina e começa sua diferenciação (HAWKE \& GARRY, 2001).

Decidimos também realizar a histomorfométria das áreas dos diferentes tipos de fibras musculares a fim de verificar o quanto nosso esquema de alcoolismo crônico, estaria atuando sobre as fibras e se este induziria a miopatia alcoólica crônica, já que não utilizamos etanol puro como nos demais modelos pesquisados para este fim, além de procurar estabelecer como os diferentes tipos de fibras se comportariam mediante o treinamento e o sedentarismo, destes animais.

Utilizamos para tanto, um procedimento histoenzimológico que divide as fibras em categorias baseando-se na “isoforma” específica da ATPase encontrada nas fibras, dependendo do pH utilizado para a reação (GUTH \& SAMAHA, 1969). No pH 9.4 as fibras tipo I aparecem com uma coloração mais claras e as fibras tipo II exibem uma coloração mais escura. Não é possível se visualizar as fibras intermediárias, senão com o emprego do pH 4.6 que cora as fibras tipo I em cores escuras e as fibras tipo IIa bem claras e as tipo IIb em tom intermediário entre as cores exibidas pelas fibras I e IIa. 
FERNÁNDEZ-SOLÁ et al. (1995), estudaram a atrofia da fibra muscular tipo II na miopatia alcoólica crônica. Utilizaram para a análise histomorfométrica dos tipos de fibras musculares pela coloração ATPase, o Microm Image Processing Operative System (Microm Barcelona, Spain) com IMCO 10 processador de imagem associado a um programa de computador para realizar a contagem da área e do diâmetro de cada tipo de fibra muscular, processando mais ou menos 200 fibras em sua análise, nos pHs 9.4, 4.6 e 4.3.

Para a realização do processo de histoenzimologia, decidimos por escolher o músculo gastrocnêmio e o músculo sóleo, pois o gastrocnêmio é um músculo que apresenta proporcionalmente fibras do tipo I (aeróbica) e tipo II (anaeróbica) em quantidades equivalentes e no músculo sóleo predominam as fibras do tipo I (aeróbica) (VILA et al, 2001).

Os músculos gastrocnêmio e o sóleo utilizados nesta investigação foram retirados do membro inferior contra lateral à lesão, pois a região da lesão por impacto era em relação ao tamanho do músculo, relativamente ampla.

MINAMOTO et al. (1999) demonstraram também que não há diferenças significativas entre os tipos de fibras do músculo lesado e não lesado após 30 dias da lesão.

Na análise morfométrica da área dos tipos de fibras musculares dos músculos sóleo do grupo alcoólatra sedentário, observamos que a musculatura analisada não chegou a apresentar uma miopatia alcoólica “característica”, com uma diminuição importante da área da fibra tipo II característica encontrada por MASTAGLIA \& WALTON, 1982.

Acreditamos que o tipo de protocolo de alcoolismo crônico utilizado, com a ingestão de aguardente de cana diluída, possa ter levado a musculatura esquelética apresentar uma sensibilização dos tipos de fibras ou uma miopatia alcoólica aguda, caracterizada por dor muscular inflamatória e alteração em ambos os tipos de fibra muscular como relatam PREEDY et al. (2001b, 2002). 
Apesar do grupo alcoólatra sedentário apresentar uma redução significativa $(\mathrm{p}<0,01)$ na área do tipo de fibra II, acreditamos que esta redução esteja relacionada ao sedentarismo e não ao alcoolismo, uma vez que também observamos uma redução significativa $(\mathrm{p}<0,01)$ na área da fibra tipo II no grupo sedentário água e pelo fato que indivíduos sedentários apresentam cerca de 47-53\% de fibras tipo I (POWERS \& HOWLEY, 2000).

Outra explicação para o aumento das fibras tipo I nos grupos sedentários é a própria composição do músculo sóleo, que apresenta predomínio de fibras tipo I (aeróbica) (VILA et al, 2001).

Quando comparamos os grupos de animais treinados, verificamos um aumento significativo das fibras tipo II nos animais alcoólatras treinados, o que não foi observado nos animais controles. Este resultado possivelmente estaria relacionado ao fato dos animais realizarem "picos” de corrida na esteira durante o treinamento programado aumentando desta forma a porcentagem de fibras rápidas (tipo II) (POWERS \& HOWLEY, 2000).

$\mathrm{Na}$ análise morfométrica da área dos tipos de fibras musculares dos músculos gastrocnêmio do grupo dos animais sedentários, observamos que não houve alteração significativa $(\mathrm{p}>0,01)$ entre os animais que ingeriram água e os que ingeriram álcool. Acreditamos este resultado seja devido ao fato do músculo gastrocnêmio apresentar proporcionalmente fibras do tipo I (aeróbica) e tipo II (anaeróbica), e ou que o nosso esquema de alcoolismo crônico utilizado, provocaria apenas uma miopatia aguda.

No grupo treinado, observamos um aumento significativo $(\mathrm{p}<0,01)$ da área das fibras tipo II, possivelmente devido ao fato dos animais realizarem "picos” de corrida na esteira durante o treinamento aumentando desta forma a porcentagem de fibras rápidas (tipo II).

Foi verificado um aumento significativo $(\mathrm{p}<0,01)$ nas áreas das fibras tipo I e tipo II dos animais treinados, o que era esperado, em decorrência ao treinamento físico que leva a um aumento da massa muscular (POWERS \& HOWLEY, 2000) e conseqüentemente um aumento na área das fibras. 
Observamos uma redução significativa $(\mathrm{p}<0,01)$ na área das fibras tipo I e tipo II nos animais que ingeriram álcool. Este resultado reforça nossa idéia de que nosso esquema de alcoolismo crônico sensibilizou ambos os tipos de fibras musculares, como o que se encontra na miopatia alcoólica aguda.

A habilidade de regeneração da musculatura esquelética tem sido documentada desde a segunda metade do século XVIII, porém, aproveita-se à oportunidade de dizer que muitos dos fatos relacionados à regeneração do músculo esquelético, estão ainda hoje sendo estudados e, há muito ainda a ser descoberto.

Por termos realizado o sacrifício dos animais 96 horas após a lesão associada ao tratamento com o USP, nossa avaliação ficou reduzida aos aspectos característicos da fase inflamatória ou inicial, o qual, geralmente perdura por cerca de 4 dias após a lesão.

$\mathrm{Na}$ análise histológica da área de impacto, pudemos observar que os grupos alcoólatras tiveram um aumento no infiltrado inflamatório, possivelmente devido à sensibilização causada pelo álcool sobre a musculatura esquelética (miopatia alcoólica aguda) (PREEDY et al., 2001b, 2002), pois, segundo BASSOLI (2001), após 3 dias de estímulo com o USP, deveríamos observar uma redução das células inflamatórias e intensa neoformação vascular, como observamos nos nossos grupos experimentais, controles sedentários e treinados.

Verificamos que o infiltrado inflamatório no grupo treinado alcoólatra era maior que no grupo sedentário alcoólatra, acreditamos, que este fato se deva à associação entre o treinamento e o uso continuado do álcool, pois, ambos alteram a bioquímica muscular e podem levar a lesões musculares.

Nos grupos controles, sedentário e treinado, observamos uma melhora considerável no infiltrado inflamatório, principalmente no grupo treinado, nos levando a crer que a atividade física teria atuado beneficamente no processo de reparo, como era esperado segundo GREGORY et al. (1995) e WANEK \& SNOW (2000), porém, não podemos afirmar qual dos grupos, sedentários ou treinados, obtiveram melhores resultados regenerativos, uma vez que não utilizamos nenhuma forma de análise mais profunda dos aspectos de reparo, como, por exemplo, contagem de células satélites ativas ou a contagem de vasos neoformados. 


\section{XII.CONCLUSÃO}

Os resultados obtidos, consoante à metodologia utilizada, nos permite concluir que na análise histopatológica da evolução temporal da regeneração das lesões por impacto associadas ao tratamento com ultra-som pulsado de baixa intensidade em animais alcoólatras tiveram suas fases de regeneração comparada aos dos animais controles, no período por nós convencionados.

Podemos concluir também que nosso esquema de alcoolismo crônico não foi eficiente para levar a uma miopatia alcoólica crônica, provocando somente uma sensibilização das fibras musculares, uma vez que a análise das áreas das fibras musculares, tipo I e II dos animais alcoólatras tiveram uma redução significativa quando comparado aos tipos de fibras dos animais controles. 


\section{REFERÊNCIAS BIBLIOGRÁFICAS}

ABERNETHY PJ, THAYER R, TAYLOR AW. (1990). Acute and chronic responses of skeletal muscle to endurance and sprint exercise: A review. Sports Med, v. 10, n. 6, p. 365-89.

ADACHI, J.; ASANO, M.; UENO, Y.; NIEMELA, O.; OHLENDIECK, K.; PETERS, T.; PREEDY, V.R. (2003). Alcoholic muscle disease and biomembrane perturbations. J Nutr Biochem, v.14, n. 11, p. 616-625, nov.

ALBERTIN, L.M. (1983). Efeito do ultra-som no reparo de falha óssea experimental: Avaliação quantitativa e morfológica do parâmetro tempo de estímulo. São Carlos. Dissertação (Mestrado). Escola de Engenharia de São Carlos/ Faculdade de Medicina de Ribeirão Preto, Universidade de São Paulo - USP.

ALBROOK, D. (1962). An electron microscopic study of regenerating skeletal muscle. J.Anat., v. 96, n. 2, p. 137-52.

ALVES, J.M. (1988). Efeitos da energia ultra-sônica na regeneração de pele animal com queimadura por calor. São Carlos. Dissertação (Mestrado). Escola de Engenharia de São Carlos/ Faculdade de Medicina de Ribeirão Preto, Universidade de São Paulo USP.

AMÂNCIO, A.C.G. (2003) Efeitos do ultra-som terapêutico na integração de enxertos de pele total em coelhos. São Carlos, 2003. 53f. Dissertação (Mestrado). Escola de Engenharia de São Carlos / Faculdade de Medicina de Ribeirão Preto e Instituto de Química de São Carlos, Universidade de São Paulo - USP.

BAKER, K.G.; ROBERTISON, V.J.; DUCK, F.A. (2001). A review of therapeutic ultrasound: Biophysical effects. Physical Therapy, v. 81, n. 7, p. 1351-58, july.

BASSOLI, D.A. (2001). Avaliação dos efeitos do ultra-som pulsado de baixa intensidade na regeneração de músculos esqueléticos com vistas à aplicabilidade em clínica fisioterapêutica. São Carlos, 2001. 93f. Dissertação (Mestrado). Escola de Engenharia de São Carlos / Faculdade de Medicina de Ribeirão Preto e Instituto de Química de São Carlos, Universidade de São Paulo - USP.

BISCHOFF, R. (1975) Regeneration of single skeletal muscle fibers in vitro. Anat. Rec., v.182, p. 215-236.

BODINE-FLOWLER, S. (1994) Skeletal muscle regeneration after injury - An Overview. Journal of Voice, v. 8, n. 1, p. 53-62. 
BRASSEUR G. ONOLFO JP, COPIN H. LEPERCHEY F. BARBET JP. (1997) Degeneration and regeneration of skeletal muscle fibers in Duchenne muscular dystrophy. Morphologie 1997 Marc, 81( 252): 9-13.

CAMPANELLI, F. (2004). Efeitos da radiação ultra-sônica pulsada e de baixa intensidade sobre o Mal Perfurante Plantar (MPP), manifestação cutânea decorrente da Hanseníase. São Carlos, 2004. Dissertação (Mestrado) - Escola de Engenharia de São Carlos/ Faculdade de Medicina de Ribeirão Preto/ Instituto de Química de São Carlos, Universidade de São Paulo.

CAMPION, D.R. (1984). The muscle satellite cell: a review. International Review of Citology, v. 87, p.225-251.

CARBONARI, R.C. (2003) Projeto de atuadores piezelétricos flextensionais usando o método de otimização topológica. São Paulo, 2003. 168p. Dissertação (Mestrado).Escola Politécnica da Universidade de São Paulo, Universidade de São Paulo - USP.

CARLSON, B.M.; FAULKNER, J.A. (1983) The regeneration of skeletal muscle fibers following injury: a review. Medicine and Science in Sports and Exercise. v. 15, n. 3, p.187-198.

CASTRO, R. (1995) Estrela Solitária: Um Brasileiro Chamado Garricha. 1ª .edição. São Paulo:Companhia das letras, 1995.

CHOU, S.M.; NONADA, I. (1997). Satellite cells and muscle regeneration in diseased human skeletal muscles. Journal of Neurological Sciences, v. 34, p.131- 45.

COAKLEY, W.T. (1978) Biophysical effects of ultrasound at therapeutic intensities. Physiotherapy, v. 64, n. 6, p. 166-9

COLUCCI, A.R.S. (2002). Estudo do ultra-som de baixa intensidade na osseointegração de implantes de titânio em tíbia de coelho: avaliação histomorfométrica e mecânica. São Carlos, 2002. 83f. Dissertação (Mestrado). Escola de Engenharia de São Carlos/ Faculdade de Medicina de Ribeirão Preto e Instituto de Química de São Carlos, Universidade de São Paulo - USP.

CRISCI, A.R. (2001). Estudo experimental dos efeitos do ultra-som pulsado de baixa intensidade na regeneração do nervo ciático de ratos após neurotomia, mediante avaliação morfológica e morfométricas. São Carlos, 2001. 100f. Dissertação (Mestrado). Escola de Engenharia de São Carlos/ Faculdade de Medicina de Ribeirão Preto e Instituto de Química de São Carlos, Universidade de São Paulo - USP.

CRISCO, J.J.; JOKI, P.; HEINEN, G.T.; CONNELL, M.D.; PANJABI, M.M. (1994) A muscle contusion injury model. The American Journal of Sports Medice, v. 22, n.5, p.702-710. 
CRUZ, A. F. (2005). Estudo dos efeitos da irradiação ultrasônica pulsada de baixa intensidade sobre o desenvolvimento de segmento de coluna vertebral implantados em camundongos isogênicos. São Carlos, 2005. 113f. Dissertação (Mestrado). Escola de Engenharia de São Carlos/ Faculdade de Medicina de Ribeirão Preto e Instituto de Química de São Carlos. Universidade de São Paulo - USP.

DELUCIA, R.; OLIVEIRA FILHO, R.M. (2004). Farmacologia Integrada. $2^{\mathrm{a}}$. ed. Rio de Janeiro: Revinter. 678p.

DUANE, P.; PETERS, T.J. (1988) Nutritional status in alcoholics with and without chronic skeletal myopathy. Alcohol Alcohol. v.23, p.271-277.

DUARTE, L.R. (1977). Estimulação ultra-Sônica do calo ósseo. São Carlos, 1977. 129p. Tese (Livre Docência) - Escola de Engenharia de São Carlos, Universidade de São Paulo -USP.

DUBOWITZ, V. (1985) Definition of pathological changes in muscle biopsies. Changes in fibre size. In: DUBOWITZ, V. (Ed.) Muscle biopsy: A Practical Aprproach, Baillière Tindall, London, p.77-97.

FARIS, A.A.; REYES, M.G.; ABRAMS, B.M. (1967). Subclinical alcoholic myopathy: electromyografic and biopsy study. Trans. Am. Neurol. Assoc. v.92, p. 102-106.

FERNÁNDEZ-SOLÁ, J.; SACANELLA, E.; ESTRUCH, R.; NICOLÁS, J-M.; GRAU, J-M.; URBANO-MÁRQUEZ, A. (1995). Significance odf type atrofy in chronic alcoholic myopathy. Journal of Neurologic Sciences. v. 130, p. 69-76.

FISHER, B.D.; BARACOS, V.E.; SHNITKAS, T.K.; MENDRYK, S.W. (1990) Ultrastructural events following acute muscle trauma. Medicine and Science in sports and Exercise.v. 22, n. 2, p. 185-193.

FORTES, J.R.A. Alcoolismo. São Paulo: Savier, 1975.138p.

FOSCHINI, R. M. S. A.; RAMALHO, F.S.; BICAS H. E.A. (2004) Myogenic satellite cells. Arq Bras Oftalmol. v. 67, n. 4, p. 681-7.

FOX, E.L.; MATHEWS, D.K (1986). Bases fisiológicas da educação física e do desporto. $3^{\text {a }}$. ed. Rio de Janeiro: Guanabara-Koogan,. 488p.

FRY, A.C.; ALLEMEIER, C.A.; STARON, R.S. (1994) Correlation between percentage fiber type area and myosin heavy chain content in human skeletal muscle. Eur J Appl Physiol Occup Physiol, v. 68, n. 3, p. 246-51.

FUKADA, E.; YASUDA, I. (1957). On pizoeletric effect of bone. Journal Of Phisical Society of Japan. v. 12, n. 10, p. 1152-62, 1957.

GAMA, L.O.R. (2002). Artrose atlanto-axial em cães tratada por ultra-som de baixa intensidade. São Carlos, 2002. 78f. Dissertação (Mestrado). Escola de Engenharia de São Carlos. Universidade de São Paulo - USP. 
GARTNER, L.P. \& HIATT, J. L. (1999) Tratado de Histologia. $1^{\text {a }}$ ed. Rio de Janeiro: Guanabara Koogan, , 426p.

GYTON, A.C. \& HALL, J.E (2002). Tratado de Fisiologia Médica.10 .ed. Rio de Janeiro: Guanabara-Koogan. p.1013.

GRAZZIANO, C. R. (1999). O efeito do ultra-som terapêutico na regeneração do músculo esquelético. São Carlos, 1999. 85f. Dissertação (Mestrado) - Universidade Federal de São Carlos -UFSCar.

GREGORY, T.M.; HECKMANN, R.A.; FRANCIS, R.S. (1995). The effect of exercise on the presence of leucocytes, erythocytes and collagen fibres in skeletal muscle after contusion. J. Manipulative Physiol Ther, v. 78, p. 30-7.

GUIRRO, R.; SERRÃO, F.; ELIAS, D.; BUCALON A. J. (1997). Calibration of therapeutic ultrasound equipment. Physiotherapy, v. 83, p. 419 - 32.

GUIRRO, R.; GUIRRO, E. (2002). Ultra-som. In: Fundamentos, Recursos, Patologias. $3^{\text {a }}$ ed. São Paulo: Manole. 560p. . Fisioterapia Funcional:

GUTH, L.; SAMAHA F.J. (1969).Qualitative Differences between actomyosin ATPase of slow and fast mammalian Muscle. Experimental Neurology. v.25, p.138-152.

HALLER, R.G.; CARTER, N.W.; FERGUSON, E.; KNOCHEL, J.P. (1984) Serum and muscle potassium in experimental alcoholic myopathy. Neurology. v. 34, p. 529-532.

HAWKE, T.J.; GARRY, D.J. (2001). Myogenic satellite cells: physiology to molecular biology. J. Appl. Physiol. v. 91, p.534-51.

HOGAN, R.D.B.; BURKE, K.M.; FRANKLIN, T.D. (1982) The effect of ultrasound on the microvascular hemodynamics in skeletal muscle: effects during ischemia. Microvascular Research, 23: 370-379.

HOOGLAND, R. (1986). Terapia ultrasônica. Enraf-Nonius, p. 5-35.

HUDSON, P. (1984). Alcohol myopathy. Br. Med. J. 120: 584- 585.

HUNTER, R.J.; NEAGOE, C.; JARVELAINEN, H.A.; MARTIN, C.R.; LINDROS, K.O.; LINKE, W.A.; PREEDY, V.R.( 2003). Alcohol Affects the Skeletal Muscle Proteins, Titin and Nebulin in Male and female Rats. Americam Society for Nutritional Science. 1154-57.

JARVINEN, T.A.; KAARIAINEN, M.; JARVINEN, M.; KALIMO, H. (2000) Muscle strain injuries. Current Opinion in Rheumatology, Philadelphia, v.12, n. 2, p. 155-161, Mar.

JUNQEIRA, L.C.; CARNEIRO, J. (1999) Histologia Básica. 9.ed. Rio de Janeiro, Guanabara-Koogan. 512p. 
KITCHEM, S.; YOUNG, S. (1998) Princípios eletrofísicos. In: KITCHEM, S; BAZIM, S. Eletroterapia de Clayton. São Paulo: Manole. cap.3, p.46-58.

LARINI, L.; SALGADO, P.E.T. (1997). Compostos voláteis. In: LARINI, L. Toxicologia.3.ed.São Paulo: Manole, 1997. cap.4, p.73-78.

LEHNINGER, A.L. Princípios de Bioquímica. São Paulo: Savier, 1984. 725p.

LOW, J.; REED, A. (1994) Eletrotherapy explained: principles and practice. $2^{\mathrm{a}}$ ed. Butterworth Heinemann. 393p.

LOW, J.; REED, A. (2001).Ultra-som terapêutico. In: Eletroterapia Explicada: princípios e prática. $3^{\mathrm{a}}$ ed. São Paulo, Manole. p.472.

MALTIN, C.; HARRIS, J.B.; CULLEN, M.J. (1993). Regeneration of mammalian skeletal muscle following the injection of the snake-nenom toxin, paipoxin. Cell Tissue Res., v.232, p. 565-77.

MARKERT, C.D.; MERRICK, M.A.; KIRBY, T.E.; DEVOR, S.T. Nonthermail ultrasound and exercise in skeletal muscle regeneration. Arch Phys Med Rehabil., v. 86, p.1304-1310, july.

MARSTERS, S.B. (2003) Os álcoois. In: BERTRAM, G.K. Farmacologia Básica e Clínica. 8a ed. Rio de Janeiro: Guanabara-Koogan, 2003, cap. 23, p. 334-339.

MARTIN, F.; WARD, K.; SLAVIN, G.; LEVI, J.; PETERS, T.J. (1985) Alcoholic skeletal myopathy, a clinical and pathological study. Q.J. Med.v. 55. p. 233-251.

MARUENDA, C; ARMSTRONG, C.F. (1978). Satellite and invasive cells in frog sartorius muscle. Tissue and Cell, Harlow Essex, v.10, p.749

MARZZOCO, A.; TORRES,B.B. Bioquímica Básica. 2ª ed. Rio de Janeiro: Guanabara-Koogan, 1999.360p.

MASTAGLIA, F.L.; WALTON, J. (1982) Skeletal muscle pathology, $1^{\mathrm{a}}$. ed. New York: Churchill Livingstone.

McARDLE, W.D.; KATCH, F.I.; KATCH, V.L. (1991). Fisiologia do Exercício: energia, nutrição e desempenho humano. $3^{\mathrm{a}}$. ed. Rio de Janeiro: Guanabara-Koogan. 510p.

McARDLE, W.D. et al. (2001). Fisiologia do Exercício: energia, nutrição e desempenho humano. $4^{\mathrm{a}}$. ed. Rio de Janeiro: Guanabara-Koogan.

MAXWELL, L. (1995) Therapeutic ultrasound and tumor mestatasis. Physiotherapy, 81(5): 272-5.

MINAMOTO, V.B.; GRAZZIANO, C.R.; SALVINI, T. F. (1999) Effect of single and periodic contusion on the rat soleus muscle at different stage of regeneration. Anatomic Record, Philadelphia, v. 16, p. 61-87. 
OHLENDIECK, K.; HARMON, S.; KOLL, M.; PAICE, A.G.; PREEDY, V.R. (2003) $\mathrm{Ca}^{2+}$ - Regulatory Muscle Proeins in the Alcohol-Fed Rat. Metabolism. v. 52, p. 11021112.

OKUNO, E; CALDAS, I.L.; CHOW, C. (1982). Física para ciências biológicas e biomédicas. São Paulo: Harbra, 490p.

OLIVEIRA, F.B. (2004). O ultra-som terapêutico adicionado à imobilização gessada nas propriedades mecânicas da reparação muscular pós-trauma por mecanismo de impacto. Ribeirão Preto, 2004. 126f. Dissertação (Mestrado). Escola de Engenharia de São Carlos/ Faculdade de Medicina de Ribeirão Preto e Instituto de Química de São Carlos, Universidade de São Paulo - USP.

PACHIONO, C.A.S. (1996). Lesão por estiramento do músculo soleus: estudo experimental em ratos. Ribeirão Preto, 1996. 60f. Dissertação (Mestrado). Escola de Engenharia de São Carlos/ Faculdade de Medicina de Ribeirão Preto e Instituto de Química de São Carlos, Universidade de São Paulo - USP.

POWERS, S.K. \& HOWLEY, E. T. Fisiologia do exercício: teoria e aplicação ao condicionamento e ao desempenho. $1^{\text {a }}$. edição brasileira. São Paulo: Manole, 2000. 527p.

PREEDY, V.R.; PETERS, T.J. (1990). Alcohol and skeletal muscle disease. Alcohol Alcoholism, 25: 177-187.

PREEDY, V.R.; PETERS, T.J.; PATEL, V.B.; MIELL, J.P. (1994) Chronic alcoholic myopathy: transcription and translational alterations. FASEB J. v. 8, n. 14, p.1146-51.

PREEDY, V.R.; PAICE, A.; MANTLE, D; DHILLON, A.S.; PALMER, T.N.; PETERS, T.J. (2001a). Alcoholic myopathy: biochemical mechanisms. Drug and Alcohol Dependence. v. 63, p. 199-205.

PREEDY, V.R.; ADACHI, J.; UENO, Y.; AHMED, S.; MANTLE, D.; MULLATTI, N.; RAJENDRAM, R.; PETERS, T.J. (2001b). Alcoholic skeletal muscle miopathy: definitions, features, contribution of neuropathy, impact and diagnosis. European Journal of Neurology. v. 8, n. 6, p.677- 687.

PREEDY, V.R.; ADACHI, J.; ASANO, M.; KOLL, M.; MANTLE, D.; NIEMELA, O.; PARKKILA, S.; PAICE, A.G.; PETERS, T.; RAJENDRAM, R.; SEITZ, H.; UENO, Y.; WORRAL, S. (2002). Free radicals in alcoholic myopathy: indices of damage and preventive studies. Free Radical Biology \& Medicine. v. 32, n. 8, p. 683- 687.

PREEDY, V.R.; OHLENDIECK, K.; ADACHI, J.; KOLL, M.; SNEDDON, A.; HUNTER, R.; RAJENDRAM, R.; MANTLE, D.; PETERS, T.J. (2003). The importance of alcohol- induce muscle disease. Journal of Muscle Research and Cell Motility. v. 24, p. 55- 63. 
RAMALHO JÚNIOR, F.; SANTOS, J.I.C.; FERRARO, N.G.; SOARES, P.A.T. (1940) Os fundamentos da física: termologia, óptica geométrica e ondas. $3^{\mathrm{a}}$ ed. São Paulo: Moderna, 358p.

RANTANEN, J.; THORSSON O.;WOLLMER P.; HURME T.;KALIMO H. (1999) Effects of Therapeutic Ultrasound on the Regeneration of Skeletal Myofibers After Experimental Muscle Injury.The Americam Journal of Medicine, v. 27, n.1.

RICHARDSON, P.D. (1989). Piezoelectric plymers. IEEE. Medicine and Biology Magazine, jun.

ROCHA, B. Aparelhos sensoriais: ouvido. Disponível em:

$<$ http://www.corpohumano.hpg.ig.com.br/apr_sensoriais/ouvido/ouvido_a.jpg > Acesso em 05 de out. 2005.

ROSS, M.H.; ROMRELL, L.J. (1993). Histologia: texto e atlas. 2.ed. São Paulo, Panamericana.

SENE, G.L. (2005) Influência do laser de baixa intensidade nas propriedades mecânicas do músculo gastrocnêmio submetidos à lesão muscular por mecanismo de impacto. Ribeirão Preto, 2005. 89f. Dissertação (Mestrado). Escola de Engenharia de São Carlos/ Faculdade de Medicina de Ribeirão Preto e Instituto de Química de São Carlos, Universidade de São Paulo - USP.

SHRIBER, W.J. (1975). A manual of electrotherapy. London: [s.n.]

SIMÃO, R. (2003). Fundamentos Fisiológicos para o Treinamento de Força e

Potência. 1ed. São Paulo: Phorte. 304p.

SLAVIN, G.; MARTIN, F.; WARD, P.; LEVI, J.; PETERS, T. (1983). Chronic alcohol excess is associated with selective but reverseble injurey type II B muscle fibres. J. Clin. Pathol., 36: 772-777.

SMITH, L.K.; WEISS, E.L.; LEHMKUHL, L.D. (1997). Cinesiologia Clínica de Brunnstrom. 1.ed. São Paulo: Manole. 538p.

SILVA,O.L. (1987). Estudo do mecanismo de ação do ultra-som na estimulação do tecido ósseo. São Carlos. 215f. Dissertação (Mestrado). Escola de Engenharia de São Carlos Universidade de São Paulo - USP.

TER HAAR, G. (1978). Basic physics of therapeutic ultrasound. Physiotherapy, v. 64, n. 4, p.100-03, april.

TER HAAR, G. (1987). Basic physics of therapeutic ultrasound. Physiotherapy, v. 73, n. 3, p.100-13, mar.

TER HAAR, G. (1987) Tissue regenerations. In: REPACHIOLI, M.H. et al. Ultrasound. Medical applications, biological effects and hazard potential. New York: Plenum Press. 
TER HAAR, G. (1998) Princípios eletrofísicos. In: KITCHEM, S; BAZIM, S. Eletroterapia de Clayton. São Paulo: Manole. cap.1, p.3-30.

TROUNCE, I.; BYRNE, E.; DENNETT, X.; SANTAMARIA, J.; DOERY, J.; PEPPARD, R. (1987). Chronic alcoholic proximal wasting: physiological, morphological and biochemical studies in skeletal muscle. Aust. NZ J. Med., v. 17, p.413-419.

VILA, L.; FERNANDO, A.; VOCES, J.; CABRAL DE OLIVEIRA, C.; PIETRO, J.G.; ALVAREZ, A.I. (2001). Effect of chronic ethanol ingestion and exercise training on skeletal muscle in rat. Drug Alcohol Depend. v. 64, n.1, p. 27-33, sep.

WANEK, L.J.; SNOW, M.H. (2000). Activity-induced fiber regeneration in rat soleus muscle. Anat Rec. v. 258. p. 176-85.

WELLS, P.N.T. (1977). Velocity, absorption and attenuation biological materials. In: Biomedical Ultrasonic. London: Academic Press, 635p.

WILLIANS, A.R. (1974) Release of serotonin from platelets by acoustic streaming. Journal of the Acoustic Society of American, 56:116,121.

WILLIANS, A.R.; SYKES, S.M.; O`BRIE N, W.D. (1976) Ultrasonic expouse modities platelets morphology and function in vitro. Ultrasound Med. Biol, 2: 311-317.

WILLIAMS, R.A. (1983). Ultrasound: biological effect and potential hazards. $2^{\mathrm{a}}$ ed. London: Academic Press.

WILLIANS, P.L.; WARWICK, R.; DYSON, M.; BANNISTER, L.H. (1995). Gray Anatomia. Rio de Janeiro: Guanabara-Koogan. v.1.

WORDEN, R.E. (1976). Pattern of muscle and nerve pathology in alcoholism. Ann. NY Acad. Sci. v. 273, p.351-359.

WORRAL, S.; NIEMELA, O.; PARKKILA, S.; PETERS, T.; PREEDY, V.R. (2001). Protein adducts in type I and type II fibre predominant muscle of ethanol-fed rat: preferential localization in the sarcolemmal and subsarcolemmal region. European Journal Clinical Investigation, 31: 723-730.

YOUNG, S.R. \& DYSON, M. (1978). Macrophage responsivenesess to therapeutic ultrasound. Ultrasound in Medicine and Biology. v. 16, n. 8, p. 809-16.

YOUNG, S.R. (1990). The effect of therapeutic ultrasound on the biological mechanisms envolved in dermal repair. London. Thesis (PhD) - University of London.

YOUNG, S. (1998) Princípios eletrofísicos. In: KITCHEM, S; BAZIM, S. Eletroterapia de Clayton. São Paulo: Manole. cap.15, p.235-257. 
ZISKIN, M.C.; LEWIN P.A. (1993) Physical of Ultrasound. In: Ultrasonic Exposimetry. Boca Ranton: Academic Press. cap.1, p.37. 